\title{
DOSES DE N E K APLICADAS VIA FERTIRRIGAÇÃO NA CULTURA DO COQUEIRO (Cocos nucifera L.) ANÃO
}

Miguel FERREIRA NETO

Tese apresentada à Escola Superior de Agricultura "Luiz de Queiroz", Universidade de São Paulo, para obtenção do título de Doutor em Agronomia, Área de Concentração: Irrigação e Drenagem.

P I R A C I C A B A

Estado de São Paulo - Brasil

Maio - 2005 


\title{
DOSES DE N E K APLICADAS VIA FERTIRRIGAÇÃO NA CULTURA DO COQUEIRO (Cocos nucifera L.) ANÃO
}

\section{MigUel FERREIRA NeTO}

Engenheiro Agrônomo

Orientador: Prof. Dr. MARCOS VINÍCIUS FOLEGATTI

\begin{abstract}
Tese apresentada à Escola Superior de Agricultura "Luiz de Queiroz", Universidade de São Paulo, para obtenção do título de Doutor em Agronomia, Área de Concentração: Irrigação e Drenagem.
\end{abstract}

P I R A C I C A B A

Estado de São Paulo - Brasil

Maio - 2005 
Dados Internacionais de Catalogação na Publicação (CIP) DIVISÃO DE BIBLIOTECA E DOCUMENTAÇÃO - ESALQ/USP

Ferreira Neto, Miguel

Doses de N e K aplicadas via fertirrigação na cultura do coqueiro (Cocos nucifera

L.) Anão / Miguel Ferreira Neto. - - Piracicaba, 2005 $105 \mathrm{p}$.

Tese (doutorado) - - Escola Superior de Agricultura Luiz de Queiroz, 2005. Bibliografia.

1. Coco 2. Fertilidade do solo 3. Fertirrigação 4. Fisiologia vegetal 5. Nitrogênio 6. Nutrição vegetal 7. Potássio I. Título

CDD 634.61 
Aos meus pais que pelo amor se esforçaram para superar as dificuldades, me proporcionando realizar meus objetivos.

\section{DEDICO}

À minha amada esposa, Lorrainy, pelo amor, incentivo e apoio. 


\section{AGRADECIMENTOS}

A DEUS, pela razão de minha existência e sua presença em todos os momentos da minha vida.

Ao Departamento de Engenharia Rural da ESALQ/USP, pela oportunidade concedida à realização deste curso e pelos recursos financeiros concedidos para o desenvolvimento do projeto de pesquisa.

À CAPES, pela concessão da bolsa de estudo.

Ao prof. Dr. Marcos Vinícius Folegatti, pela orientação, amizade e confiança que depositou na minha pessoa e no meu trabalho.

À Empresa Agropecuária do Rio Grande do Norte (EMPARN) pela oportunidade e apoio concedidos para realização deste trabalho.

Ao Prof. Hans Raj Gheyi, pela orientação dedicada, estímulo, amizade e, sobretudo, pela confiança que sempre depositou na minha pessoa e no meu trabalho.

Ao Dr. José Simplício de Holanda, EMBRAPA/EMPARN, pela confiança, amizade, ensinamentos e apoio em todas as etapas deste trabalho.

Ao professor Sérgio Nascimento Duarte (DER - ESALQ/USP) pelas sugestões para o engrandecimento deste trabalho, lembrando dos ensinamentos, consideração e amizade.

Ao Pesquisador Ênio Farias de França, pela disposição em ajudar na melhoria e engrandecimento deste trabalho, pelo amigável convívio e incentivos constantes nas horas decisivas.

Ao Técnico Agrícola Marcos Tomaz, EMPARN, pela valiosa dedicação e contribuição na realização dos trabalhos de campo. 
Ao professor Walter (CCA - UFPB) e ao doutorando Macio, pela valiosa ajuda na realização das análises estatísticas.

Aos Técnicos e funcionários da Fazenda experimental do Jiqui, EMPARN, pela valiosa colaboração em especial aos laboratorista Ernesto Espínola e Tarcísio Dantas, pela contribuição e ensinamentos nas análises laboratoriais.

Ao colega e amigo Ricardo Alencar, pelo apoio na realização deste trabalho.

Aos funcionários do Departamento de Engenharia Rural, pela amizade.

A todos os colegas do curso de Pós-Graduação em Irrigação e Drenagem (CPGID), pela amizade e companheirismo durante o período de realização do curso.

Em fim agradeço a todos aqueles que de uma forma ou de outra contribuíram para o sucesso deste trabalho. 
SUMARIO

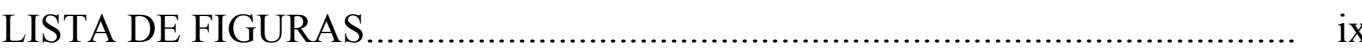

LISTA DE TABELAS …...................................................................... xii

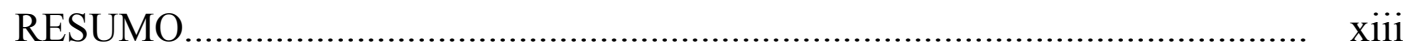

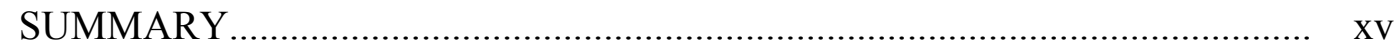

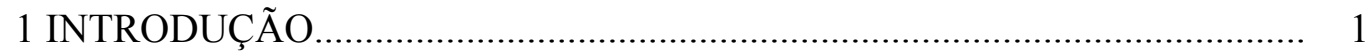

2. REVISÃO DE LITERATURA............................................................ 5

2.1 A cultura do coqueiro ........................................................................ 5

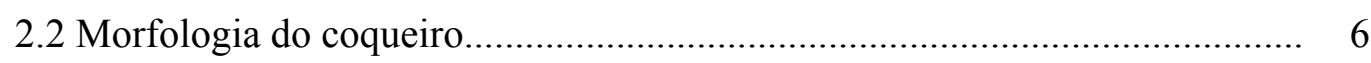

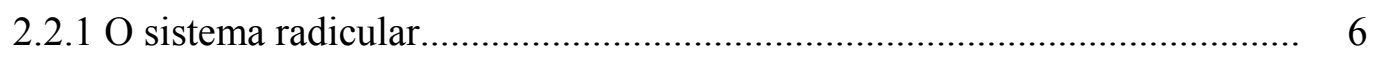

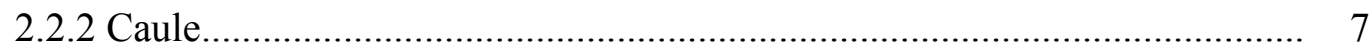

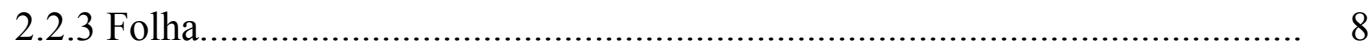

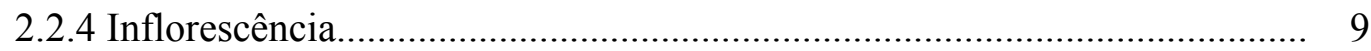

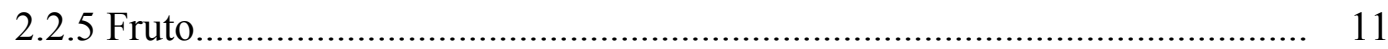

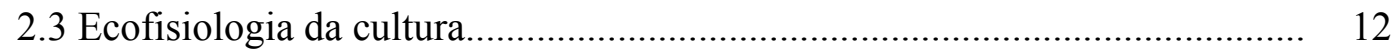

2.4 Necessidade hídrica da cultura............................................................... 13

2.5 Manejo da cultura.................................................................................... 17

2.6 Nutrição e adubação do coqueiro................................................................. 18

2.7 Níveis críticos de nutrição............................................................................. 19

2.7.1 Nitrogênio no coqueiro.................................................................... 20

2.7.2 Potássio no coqueiro..................................................................................... 23 


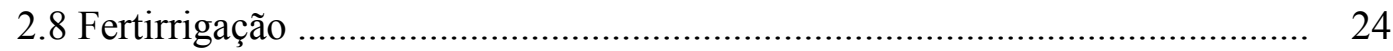

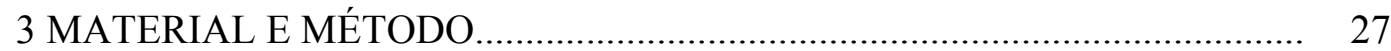

3.1 Localização e caracterização da área experimental...................................... 27

3.2 Tratamentos e delineamento experimental.................................................. 29

3.3 Condução do experimento.................................................................. 32

3.3.1 Sistema e manejo da irrigação............................................................ 32

3.3.2 Aplicação dos fertilizantes................................................................... 34

3.3.3 Aplicação de fertilizantes...................................................................... 35

3.3.3.1 Tratos culturais e fitossanitários....................................................... 36

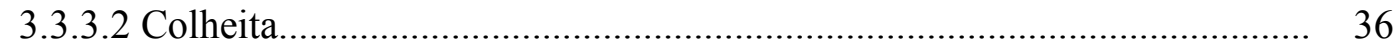

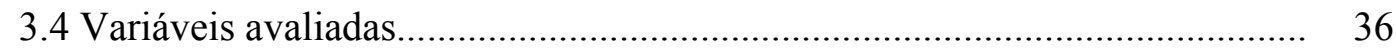

3.4.1 Desenvolvimento vegetativo.................................................................. 36

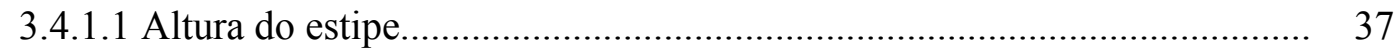

3.4.1.2 Circunferência do estipe ................................................................... 37

3.4.1.3 Diâmetro sombreado de projeção da copa................................................. 37

3.4.1.4 Emissão foliar................................................................................. 37

3.4.2 Variáveis de produção.......................................................................... 38

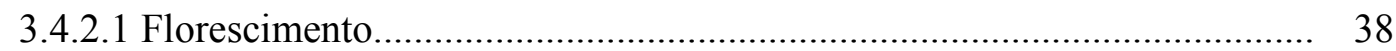

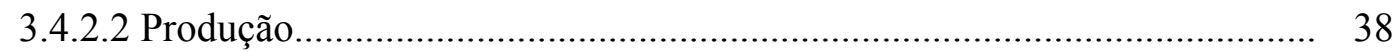

3.4.3 Qualidade da produção...................................................................... 38

3.4.4 Estado nutricional da planta................................................................ 39

3.4.5 Fertilidade do solo........................................................................ 39

3.4.6 Processamento de dados e parâmetros avaliados........................................ $\quad 40$

4 RESULTADOS E DISCUSSÃO............................................................. 41

4.1 Características meteorológicas do período de cultivo experimental............... 41

4.2 Avaliação do sistema de irrigação................................................................... 43

4.3 Desenvolvimento Vegetativo...................................................................... 44

4.4 Variáveis de produção............................................................................ $\quad 50$

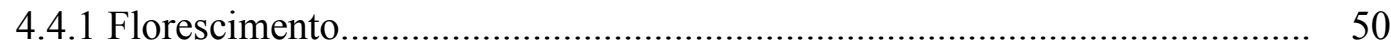

4.4.2 Produção de frutos.................................................................................. 52 
4.5 Qualidade da Produção............................................................................... 56

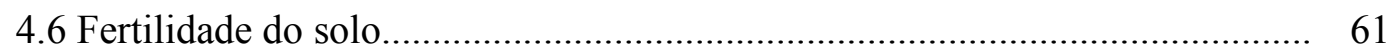

4.6.1 Profundidade e época de amostragem....................................................... 61

4.6.2 Características químicas........................................................................ 66

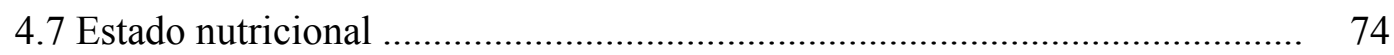

5 CONCLUSÕES

REFERÊNCIAS BIBLIOGRÁFICAS......................................................... 90 


\section{LISTA DE FIGURAS}

1 Vista geral do Campo Experimental do Jiqui............................................ 27

2 Disposição das plantas escolhidas na área experimental............................ 31

3 Variação das temperaturas máxima, média e mínima e umidade relativa média do ar durante o período de abril de 2002 a março de 2003 (A) e de abril de 2003 a março de 2004 (B).................................................................

4 Variação da Evapotranspiração de referência (A) e chuvas acumuladas (B) durante o período de abril de 2002 a março de 2003 (A) e de abril de 2003 a março de 2004 (B).

5 Altura do estipe durante o período chuvoso e de estiagem em função de doses de potássio.

6 Superfície de resposta relacionando o perímetro do estipe do coqueiro com doses de potássio e nitrogênio.

7 Número de folhas vivas por planta durante o período chuvoso em função de doses de potássio (A) e superfície de resposta do período de estiagem (B) em função de doses de potássio e nitrogênio.

8 Superfície de resposta relacionando diâmetro sombreado do coqueiro com doses de potássio e nitrogênio.

9 Superfície de resposta do número total de flores do coqueiro em função de doses de potássio e nitrogênio.

10 Superfície de resposta do número total de frutos colhidos no $6^{\circ}$ ano de cultivo, em função de doses de potássio e nitrogênio aplicadas via fertirrigação 
11 Número total de frutos colhidos no $7^{\circ}$ ano de cultivo, em função das doses de nitrogênio aplicadas via fertirrigação.

12 Caracterização dos valores médios de $\mathrm{pH}$, volume e CEac da água de coco em função de doses de potássio e nitrogênio aplicadas via fertirrigação.......

13 Superfície de resposta relacionando o ${ }^{\circ}$ Brix da água de coco, com doses de potássio e nitrogênio aplicadas via fertirrigação.

14 Teor médio de K no perfil do solo de acordo com as doses de K aplicadas. $\quad 61$

15 Teor de K no solo a 0-5 cm, 0-20 cm e 20-40 cm, em função das doses de $\mathrm{K}$ aplicadas em três períodos de amostragem do solo.

16 Valor de $\mathrm{pH}$ no solo no $1^{\mathrm{o}}$ e $2^{\circ}$ ano de estudo, em função das doses de nitrogênio aplicadas na fertirrigação

17 Concentração de Ca (A), Mg (B), P (C) e K (D) no solo em função das doses de nitrogênio e potássio aplicadas sob fertirrigação no $1^{\circ}$ ano de estudo.

18 Concentração de Ca (A), $\mathrm{Mg}$ (B), K (C) e P (D) no solo em função das doses de nitrogênio e potássio aplicadas sob fertirrigação no $2^{\circ}$ ano de estudo em período de maior intensidade de chuva (junho de 2003)

19 Concentração de $\mathrm{K}$ (A), Ca (B) e Mg (C) no solo em função das doses de nitrogênio e potássio aplicadas sob fertirrigação no $2^{\circ}$ ano de estudo em período de menor intensidade de chuva (dezembro de 2003).

20 Teor de nitrogênio em folhas de coqueiro no $7^{\circ}$ ano de produção para duas épocas de amostragem (junho e dezembro de 2003) em função das doses de potássio aplicadas via fertirrigação.

21 Teor de fósforo em folhas de coqueiro no $6^{\circ}$ e $7^{\circ}$ ano de produção (junho e dezembro de 2003), em função das doses de potássio aplicadas via fertirrigação.

22 Superfície de resposta do teor de potássio em folhas de coqueiro no $6^{\circ}$ e $7^{\circ}$ ano de produção (junho e dezembro de 2003), em função das doses de nitrogênio e potássio aplicadas via fertirrigação.

23 Correlação entre a concentração de $\mathrm{K}$ na folha com a produção média de frutos no $6^{\circ}$ e $7^{\circ}$ ano de produção, em função das doses de potássio aplicadas via fertirrigação. 
24 Superfície de resposta do teor de magnésio em folhas de coqueiro no $6^{\circ} \mathrm{e}$ $7^{\circ}$ ano de produção (junho e dezembro de 2003), em função das doses de nitrogênio e potássio aplicadas via fertirrigação.

25 Superfície de resposta do teor de sódio em folhas de coqueiro no $6^{\circ}$ e $7^{\circ}$ ano de produção, em função das doses de nitrogênio e potássio aplicadas via fertirrigação.

26 Concentração de $\mathrm{Cl}$ na folha no $6^{\circ}$ ano de produção, em função das doses de potássio aplicadas via fertirrigação

27 Teor de zinco (A) e ferro (B) em folhas de coqueiro no $6^{\circ}$ ano de produção, em função das doses de nitrogênio e potássio aplicadas via fertirrigação

28 Teor de manganês em folhas de coqueiro no $6^{\circ}$ e $7^{\circ}$ ano de produção, neste para duas épocas de amostragem (junho e dezembro de 2003), em função das doses de nitrogênio aplicadas via fertirrigação. 


\section{LISTA DE TABELAS}

1 Níveis críticos de macronutrientes na matéria seca da folha intermediária do coqueiro anão em estádio de produção.

2 Níveis críticos de micronutrientes na matéria seca da folha intermediária do coqueiro anão em estádio de produção.

3 Características* físico-hídricas do solo na área experimental.

4 Características químicas do solo antes e depois da pesquisa anterior na área experimental.

5 Tratamentos e suas respectivas doses de $\mathrm{N}$ e K, uréia e cloreto de potássio aplicadas durante o ano ${ }^{1}$ e por evento ${ }^{2}$ de fertirrigação.

6 Características químicas da água utilizada na irrigação do coqueiro.

7 Resumo da análise de variância dos componentes de qualidade dos frutos de coco verde sobre os valores médios de peso, volume, $\mathrm{pH}$, condutividade elétrica (CEac) e ${ }^{\circ}$ Brix da água de coco.

8 Médias dos teores de $\mathrm{Ca}, \mathrm{Mg}, \mathrm{P}$ e $\mathrm{K}$ nas profundidades de $0-5 \mathrm{~cm}, 0-20 \mathrm{~cm}$ e de $20-40 \mathrm{~cm}$ para os diferentes tratamentos nos períodos de fevereiro e junho de 2003, e em fevereiro de 2004

9 Médias dos teores de $\mathrm{Ca}, \mathrm{Mg}, \mathrm{P}$ e $\mathrm{K}$ na profundidade de 0-20 $\mathrm{cm}$ de acordo com cada tratamento para a época chuvosa e seca (junho e dezembro de 2003, respectivamente).

10 Análise de variância dos teores de $\mathrm{pH}, \mathrm{Al}, \mathrm{Ca}, \mathrm{Mg}, \mathrm{P}, \mathrm{K}$ e $\mathrm{Na}$ para profundidade de $0-20 \mathrm{~cm}$ de acordo com cada amostragem (dezembro de 2002, junho e dezembro de 2003, respectivamente).

11 Resumo da análise de variância para concentração de macronutrientes nas folhas do coqueiro de acordo com a idade de cultivo (dezembro de 2002, junho e dezembro de 2003, respectivamente) 


\title{
DOSES DE N E K APLICADAS VIA FERTIRRIGAÇÃO NA CULTURA DO COQUEIRO (Cocos nucifera L.) ANÃO
}

\author{
Autor: MIGUEL FERREIRA NETO \\ Orientador: Prof. Dr. MARCOS VINÍCIUS FOLEGATTI
}

\section{RESUMO}

No cultivo de coco irrigado, com a mesma tendência de outras culturas, vem aumentando a utilização da técnica de fertirrigação. No Brasil, as pesquisas com a variedade anã verde são recentes, não dispondo de resultados consistentes que viabilizem um programa de ampla difusão entre os produtores. Visando atender adequadamente as exigências nutricionais das culturas irrigadas, o fornecimento de nutriente em proporções adequadas tem sido uma dificuldade enfrentada pelos produtores. Objetivou-se com este trabalho estudar os efeitos de doses de $\mathrm{N}$ e $\mathrm{K}$ via fertirrigação no desenvolvimento e na produção do coqueiro anão verde do Jiqui, bem como, avaliar os efeitos na fertilidade do solo e na nutrição do coqueiro no $6^{\circ}$ e $7^{\circ}$ ano de cultivo. O estudo, iniciado em abril de 2002 até março de 2004, foi realizado em campo experimental da Empresa de Pesquisa Agropecuária do Rio Grande do Norte (EMPARN), em Parnamirim-RN. As plantas encontram-se espaçadas 7,5 x 7,5 x 7,5m num neossolo quartizarênico. $\mathrm{O}$ delineamento estatístico adotado foi o de blocos inteiramente casualizados, com 4 repetições, utilizando para composição dos tratamentos a matriz experimental Plan Puebla III, sendo compostos da combinação de dois fatores: doses de nitrogênio e de potássio nas formas de uréia e cloreto de potássio, respectivamente, obtendo-se 10 tratamentos, definindo-se o intervalo para as doses de $\mathrm{N}$ 
(256 a 4874 g planta $^{-1}$ ano $\left.^{-1}\right)$ e K (258 a 4872 g planta $^{-1}$ ano $^{-1}$ ) aplicados via fertirrigação por microasperssão. A área útil foi composta por 200 plantas com parcelas formadas por 10 plantas, sendo destas 5 plantas úteis, e uma bordadura externa circundando o experimento. Foram avaliados o desenvolvimento vegetativo, a produtividade, os parâmetros qualitativos dos frutos, os níveis de fertilidade do solo e as concentrações de macro e micronutrientes nas folhas. O número de folhas, diâmetro de copa, altura e circunferência do estipe foram favorecidos com as doses aplicadas. As doses $2910 \mathrm{~g}$ planta $^{-1}$ ano $^{-1}$ de K e 2353 g planta $^{-1}$ ano $^{-1}$ de N, representaram maiores produções no $6^{\circ}$ ano de cultivo. No $7^{\circ}$ ano as doses de $1540 \mathrm{~g}_{\text {planta }}{ }^{-1}$ ano $^{-1}$ de K e $1539 \mathrm{~g} \mathrm{planta}^{-1}$ ano $^{-1}$ de $\mathrm{N}$, representaram maiores produções. As doses de $\mathrm{N}$ diminuíram o volume, o ${ }^{\circ} \mathrm{Brix}$ e aumentaram o pH da água de coco. As doses de $\mathrm{K}$ reduziram a CEac e elevaram o ${ }^{\circ}$ Brix da água de coco. Os teores dos nutrientes no solo apresentaram grande variação tendendo a diminuir ao longo do período. As doses de $\mathrm{N}$ diminuem os teores de $\mathrm{Ca}, \mathrm{Mg}$ e $\mathrm{pH}$, entretanto proporcioam aumento do $\mathrm{P}$ no solo e na folha do coqueiro. As concentrações $\mathrm{K}$ no solo aumentaram de acordo com o incremento das doses de $\mathrm{K}$ aplicadas tendo diminuído de acordo com a profundidade de coleta do solo. As doses de $\mathrm{K}$ aumentaram as concentrações de $\mathrm{N}, \mathrm{K}, \mathrm{Cl}$ e Fe diminuindo as de $\mathrm{Mg}$ e $\mathrm{Na}$, entretanto as doses de $\mathrm{N}$ favoreceram ao aumento das concentrações de $\mathrm{P}, \mathrm{Na}$ e Mn reduzindo as concentrações de $\mathrm{K}$ e $\mathrm{Zn}$ na folha do coqueiro. 


\section{LEVELS OF N AND K APPLIED BY FERTIGATION ON COCONUT (Cocos nucifera L.) DWARF}

Author: MIGUEL FERREIRA NETO

Adviser: Prof. Dr. MARCOS VINÍCIUS FOLEGATTI

\section{SUMMARY}

In the culture of irrigated coconut, with the same trend of other cultures, it comes increasing the use of the fertirrigação technique. In Brazil, the cultivate the dwarf coconut palm, research with variety is recent, not making use of consistent results that make possible a program of diffusion between the producers. Aiming at to adequately take care of the nutricionais requirements of the irrigated cultures, the supply of nutrient in adequate ratios has been one difficulty faced for the producers. It was objectified with this work to study the effect of $\mathrm{N}$ and $\mathrm{K}$ doses saw fertirrigação in development and the production of green dwarfed coconut palm of Jiqui, to evaluate the effect in soil fertility and nutrition of coconut palm in $6^{\circ}$ and $7^{\circ}$ year of culture. The study, initiate in April of 2002 until March of 2004, was carried through in experimental field of the Company of Farming Research, Rio Grande do Norte states, Brazil. The plants meet spaced 7.7 x 7.5 $\mathrm{x} 7.5 \mathrm{~m}$ in quartizarênico neossolo. The adopted statistical delineation was of blocks entirely casualised, with 4 repetitions, using for composition of treatments experimental one matrix Plan Puebla III, being composites of combination two factors: nitrogen and potassium doses in the forms of urea and potassium chloride, respectively, getting 10 treatments, defining itself the interval for N (256 the $4874 \mathrm{~g} \mathrm{plant}^{-1}$ year $^{-1}$ ) and K (258 the $4872 \mathrm{~g} \mathrm{plant}^{-1}$ year $^{-1}$ ) applied way fertirrigação for microsprinkler irrigation system. 
The useful area was composed for 200 plants with parcels formed for 10 plants, being of these 5 useful plants, and one external bordadura surrounding the experiment. The vegetative development, the productivity, the qualitative parameters of fruits, the levels of soil fertility and macro and micronutrients concentrations in leves had been evaluated. The number leaf, diameter of pantry, height and circumference of estipe had been favored with the applied doses. K $2910 \mathrm{~g} \mathrm{plant}^{-1}$ year $^{-1}$ and N $2353 \mathrm{~g} \mathrm{plant}^{-1}$ year $^{-1}$ of doses, had represented greaters productions in $6^{\circ}$ year of culture. In $7^{\circ}$ the $\mathrm{K} 1540 \mathrm{~g}$ plant $^{-1}$ year ${ }^{-1}$ and N $1539 \mathrm{~g} \mathrm{plant}^{-1}$ year ${ }^{-1}$ of doses, had year represented greaters productions. $\mathrm{N}$ of doses had diminished the volume, ${ }^{\circ}$ Brix and had increased $\mathrm{pH}$ of coconut water. $\mathrm{K}$ of doses had reduced the CEac and had raised ${ }^{\circ}$ Brix of coconut water. The texts of nutrients in the soil had presented great variation having tended to diminish to the long of period. $\mathrm{N}$ of doses diminish texts of $\mathrm{Ca}, \mathrm{Mg}$ and $\mathrm{pH}$, however increase of $\mathrm{P}$ in soil and leaf of coconut palm. Concentrations $\mathrm{K}$ in soil had in accordance with increased of the applied $\mathrm{K}$ having diminished in accordance with the depth collection of soil. The $\mathrm{K}$ doses increased the concentrations of $\mathrm{N}, \mathrm{K}, \mathrm{Cl}$ and $\mathrm{Fe}$ having diminished of $\mathrm{Mg}$ and $\mathrm{Na}$, the doses of $\mathrm{N}$ had however favored to increase concentrations of $\mathrm{P}, \mathrm{Na}$ and $\mathrm{Mn}$ reducing the concentrations of $\mathrm{K}$ and $\mathrm{Zn}$ in leaf coconut palm. 


\section{INTRODUÇÃO}

O Brasil é um dos maiores produtores agrícolas do mundo. O crescimento da fronteira agrícola do país, usando suas riquezas naturais de solo, água e clima; requer cautela e intensa atividade de pesquisa para gerar pacotes tecnológicos que efetivamente demonstrem para o agricultor a correta utilização do ambiente ao qual se insere.

A cultura do coqueiro (Cocos nucifera L.) está presente na maioria dos estados brasileiros, cobrindo áreas das regiões Norte, Nordeste, Sudeste e Centro-Oeste. Este crescimento ocorreu, principalmente, em virtude do aumento da demanda pelo fruto verde de coco, com interesse especial na água do coco, para consumo in natura e uso na indústria de envasamento, ocupando espaço no vultuoso mercado de refrigerantes. Nos plantios comerciais de coqueiro no Brasil, com essa finalidade de consumo, predomina a variedade Anã verde, devido à sua boa performance em termos de rendimento e qualidade da água de coco (Ferreira et al., 1997) associando a sua produção às condições de clima, recursos hídricos e solo.

O Brasil é o quarto maior produtor de coco com $5 \%$ da produção mundial FAO (2005) e com relação à produção de coco exclusivamente para consumo de água, é o maior produtor mundial. A região Nordeste do Brasil é responsável por 85,6\% da produção nacional de coco (Agrianual, 2004). A área plantada de coco no Brasil é de aproximadamente 300.000 ha (FAO, 2005). Deste total, 90.000 ha se refere ao coqueiro anão, dos quais, menos de $50 \%$ estão em produção efetiva. Isso significa dizer que a produção nacional, que em 1999 era de 280 milhões de unidades, em 2005 poderá chegar a 1 bilhão de cocos por safra. Os produtores pretendem aumentar o consumo de 
água de coco, de mais ou menos $1 \%$ para $5 \%$ em relação ao consumo de refrigerantes, que é de aproximadamente 10 bilhões de litros.

A expansão da industrialização reflete ainda o grande aumento da produção do coco-anão, variedade específica para a produção de água. Nessa perspectiva, o coqueiro se consolidará como uma das mais importantes frutícolas permanentes cultivadas.Embora o coco anão irrigado venha aumentando sua participação na cocoicultura brasileira, segundo Agrianual (2004) os rendimentos médios esperados para cultivo irrigado dessa variedade no $6^{\circ}$ e $7^{\circ}$ ano de cultivo, em nível de campo, ficam em torno de 32 e 54 frutos planta ${ }^{-1}$ ano $^{-1}$, respectivamente. As causas na redução de produtividade são a idade de cultivo, a baixa fertilidade dos solos, o déficit hídrico proporcionado pelo mau manejo de irrigação e a incidência de pragas e doenças.

Em cultivo de sequeiro ou irrigado, a adubação é uma das práticas de expressivo impacto na produtividade do coqueiro. Segundo Malavolta et al. (1974), o coqueiro necessita de grandes quantidades de nutrientes para formação de frutos, raízes e engrossamento do caule. Dentre os nutrientes, o potássio $(\mathrm{K})$ e o nitrogênio $(\mathrm{N})$ são os nutrientes extraídos do solo em maior quantidade, seguidos do cloro $(\mathrm{Cl})$, fósforo $(\mathrm{P})$, magnésio $(\mathrm{Mg})$, enxofre $(\mathrm{S})$ e cálcio $(\mathrm{Ca})$ (Ouvrier, 1984). A grande maioria dos estudos envolvendo necessidades de adubação do coqueiro foi realizada em condições edafoclimáticas da Ásia, com a variedade gigante. No cultivo de coco irrigado, com a mesma tendência de outras culturas, vem aumentando a utilização de fertirrigação, técnica que garante para as culturas aumento da produtividade e estabilização da oferta durante todo o ano para atender a uma demanda sempre crescente (Papadopoulos, 2001).

A utilização direta das recomendações tradicionais de adubação para coqueiro (Sobral, 1998) propostas para outras variedades e regiões, com uso em fertirrigação é bastante comum. Em razão do empirismo a adoção desta prática tem frustrado muitos agricultores. Tendo este fato em vista, para que um programa de adubação tenha sucesso, torna-se necessário o conhecimento dos solos onde está implantada a cultura, aspectos básicos de nutrição como: a remoção, a função e os sintomas de deficiências 
dos nutrientes (Sobral, 1997). No Brasil, a maioria dos produtores de coco, com plantios irrigados, cultivam o coqueiro anão, e as pesquisas com esta variedade são bem recentes, não se dispondo de resultados muito consistentes que viabilizem um programa de ampla difusão entre os produtores.

Visando atender adequadamente as exigências nutricionais das culturas irrigadas, o fornecimento de nutriente em proporções adequadas tem sido uma das maiores dificuldades enfrentadas pelos produtores. O fluxo de água pelo sistema soloplanta-atmosfera, controlado pela transpiração, tem efeito direto na velocidade e na quantidade de nutrientes absorvidos; devido a isso, a absorção muda de região para região, de acordo com as condições climáticas. Desse modo, tornam-se necessários estudos visando à definição de doses de fertirrigação adequadas para o coqueiro em cada região.

Os objetivos deste trabalho foram: (i) estudar os efeitos de doses de $\mathrm{N}$ e $\mathrm{K}$ via fertirrigação no desenvolvimento, na produção e na qualidade dos frutos do coqueiro anão cv. verde do Jiqui; (ii) determinar doses ótimas e econômicas de $\mathrm{N}$ e $\mathrm{K}$ adequadas para o coqueiro anão em fase de produção; (iii) determinar o melhor período e profundidade de amostragem do solo e da planta; (iv) avaliar o estado nutricional do coqueiro sob fertirrigação.

Tais objetivos foram estabelecidos para testar as seguintes hipóteses:

- o aumento das doses de $\mathrm{N}$ e $\mathrm{K}$ aplicadas via fertirrigação proporcionam aumento da produção e qualidade dos frutos;

- as recomendações de adubação dos laboratórios de análise de solo subestimam a demanda de nutrientes exportados pelo coqueiro anão verde em cultivo fertirrigado;

- a profundidade e a época de amostragem de solo sob condições fertirrigadas se assemelham as de cultivo e fertilização tradicional; 
- para cada nutriente que promove aumento da produção existe um nível ótimo e econômico. 


\section{REVISÃO DE LITERATURA}

\subsection{A cultura do coqueiro}

O coqueiro (Cocos nucifera L.) é uma palmeira bastante difundida nas áreas intertropicais do planeta. Sua origem mais aceita é o sudeste asiático, entre as ilhas dos oceanos Índico e Pacífico, tendo sido depois levado para a África, quando em seguida chegou a América e em toda região tropical do globo terrestre (Purseglove, 1972). Segundo Gomes (1992), as evidencias históricas apontam que o coqueiro gigante, procedente da Ilha de Cabo Verde, foi introduzido e distribuído no Brasil em 1553, pelos portugueses no litoral baiano (daí a denominação de "coco da Bahia") e o coqueiro anão somente entre 1925 e 1939, vindo do norte da Malásia.

O Brasil, quarto maior produtor mundial de coco, produziu em 2002, 5\% da produção mundial. Os três maiores produtores são Indonésia, Filipinas e Índia com $28 \%$, $27 \%$ e $19 \%$ do total mundial, respectivamente (FAO,2005). A produção nacional, em 2002, concentrava-se, regionalmente, da seguinte forma: Nordeste (73\%), Sudeste e Norte com 12\%, cada. Os estados de maior produção no ano de 2002 foram: Bahia (38\%), Pará (11\%), Ceará (10\%), Espírito Santo e Pernambuco com 8\%, cada; Sergipe e Rio Grande do Norte com 5\%, cada; Paraíba e Rio de Janeiro com 3\%, cada e Alagoas com apenas $2 \%$ (IBGE, 2003).

A cocoicultura no Brasil constitui-se numa das mais importantes culturas permanentes, principalmente para a região Nordeste, onde gera emprego, renda e gêneros alimentícios possibilitando o aproveitamento de mais de 100 produtos diferentes, como também no setor de artesanato e industria.

O coco é uma das frutas que mais se destaca na fruticultura nordestina. 
Em 2002, a cultura atingiu um total de 280.835 ha em todo o país e gerou 1,9 bilhões de frutos, com um valor total de 504,3 milhões de reais (IBGE, 2003). A cultura do coco no Estado do Rio grande do Norte é encontrada em todos os municípios, embora, na sua maioria, em forma de plantios espontâneos, plantas de fundo de quintal, ornamentação de parques, residências e jardins. O coqueiro e seus produtos estão presentes no imaginário cotidiano das pessoas que moram e visitam a região nordeste.

\subsection{Morfologia do coqueiro}

O coqueiro pertence à família Palmae, uma das mais importantes famílias da classe monocotyledoneae. É constituído de uma só espécie (Cocos nucifera L.) e de duas variedades principais: o coqueiro gigante e o coqueiro anão. Esta última divide-se em três subvariedades: verde, vermelha e amarela (Passos, 1997).

\subsubsection{O sistema radicular}

O coqueiro não possui uma raiz principal, mas sim um sistema radicular fasciculado, característico das monocotiledôneas. A base do seu tronco produz raízes, continuamente, durante toda sua vida; as mais grossas (primárias) apresentam pequena capacidade de absorção, restrita apenas a uma pequena parte clara, situada logo atrás da coifa (Frémond et al., 1975), a qual é responsável pela absorção de água e de substâncias minerais do solo. Em condições de seca, essa parte da raiz primária se suberifica, perdendo a função de absorção. Das raízes primárias partem as secundárias, de onde se originam as terciárias, que produzem radicelas, sendo estes os verdadeiros órgãos de absorção, uma vez que as raízes do coqueiro não possuem pêlos absorventes. As radicelas estão nas camadas mais superficiais do solo, podendo aprofundar-se dependendo da umidade (Passos, 1997).

Segundo Maertens et al. (1974), quando as forças de retenção de água são semelhantes em todo o perfil, a disponibilidade de água no solo depende, essencialmente, do enraizamento. A homogeneidade do solo em questão, e os sinais de 
que o sistema radicular reage com a produção de novas raízes em profundidade, durante o período seco, leva a crer que o suprimento de água é regido, principalmente, pelo grau de exploração do sistema radicular e pelo gradiente de umidade e movimento de água criados pelas raízes (Passos, 1997). Da mesma forma, a constatação de que o coqueiro não promove regulação efetiva das perdas de água em condições de déficit hídrico (Passos \& Silva, 1990) permite a suposição de que o sistema radicular pode atuar como um dos mecanismos de adaptação do coqueiro para manter o suprimento regular de água.

Vários autores confirmam que a maior concentração de raízes do coqueiro é normalmente encontrada num raio de $2 \mathrm{~m}$, a uma profundidade entre 0,2 a $0,8 \mathrm{~m}$. Kushwah et al. (1973) observaram que $74 \%$ do sistema radicular não produz ramificações além de $2 \mathrm{~m}$ do bulbo de raiz e que a maior concentração se encontra na profundidade entre 0,3 e 1,2m. Cintra et al. (1992) avaliaram o sistema radicular do coqueiro anão na fase de produção e constataram que a maior concentração de raízes encontrava-se de $0,2 \mathrm{~m}$ a $0,6 \mathrm{~m}$ de profundidade e que $70 \%$ a $90 \%$ das raízes totais distribuíam-se lateralmente de 1 a $1,5 \mathrm{~m}$ do tronco. O que favorece uma melhor distribuição das raízes são solos férteis e de textura mais leves, como também, o perfil de distribuição de umidade e nutrientes aplicados.

O coqueiro é capaz de emitir raízes adventícias sob condições de alta umidade do solo provocada por excesso de chuvas, excessiva irrigação ou acúmulo de matéria orgânica na base de seu tronco (Passos, 1997). Das raízes saem, ainda, pequenas ramificações chamadas pneumatóforos, que asseguram as trocas gasosas com a atmosfera do solo (Menon \& Pandalai, 1958).

\subsubsection{Caule}

$\mathrm{O}$ caule do coqueiro é do tipo estipe, não-ramificado, muito desenvolvido e bastante resistente. Em seu ápice, prende-se um tufo de folhas que protege sua única gema terminal. A inflorescência é a única ramificação deste caule, pois é considerado um ramo caulinar modificado (Ferri, 1973). 
A parte terminal do tronco, de onde se formam novas folhas, é tenra e comestível, constituindo o palmito, em cujo ápice situa-se seu único ponto de crescimento (Ferri, 1973).

O estipe não sofre crescimento secundário em espessura, por não haver formação de novos tecidos. Modificações nos fatores ambientais, principalmente no tocante a falta d'água, induzem alterações no seu diâmetro por causa das variações no tamanho de cada uma de suas células (Passos, 1997). A altura, depende das condições ecológicas e da idade da planta, observando-se um crescimento mais rápido na idade jovem (Child, 1974).

\subsubsection{Folha}

A folha do coqueiro é do tipo penada, com aproximadamente seis metros de comprimento quando madura, e com 200 a 300 folíolos de 90 a $130 \mathrm{~cm}$ de comprimento (Passos, 1997). Esse comprimento e o número de folíolos por folha decrescem à medida que a idade do coqueiro aumenta (Menon \& Pandalai, 1958). O comprimento da folha adulta varia com a fertilidade do solo medindo de 4 a $6 \mathrm{~m}$, com peso entre 6 a $10 \mathrm{~kg}$ cada. É necessário que a idade fisiológica da planta seja conhecida pois, algumas vezes, essa idade difere da cronológica, devido a problemas nutricionais, seca, pragas, doenças ou qualquer fator que iniba o crescimento.

Sob condições ambientais favoráveis uma planta adulta de coqueiro gigante emite de 12 a 14 folhas por ano, enquanto o coqueiro anão pode emitir 18 folhas no mesmo período (Passos, 1997). Segundo Child (1974), essas folhas permanecem vivas por um período de 36 a 42 meses, o que resulta em um número de 25 a 30 folhas por planta. Quando essas condições são desfavoráveis, principalmente por causa de estiagens prolongadas, há uma diminuição do número de folhas por árvore, por causa da redução no ritmo de emissão foliar e da menor longevidade da folha (Passos, 1997). Para Frémond et al. (1975), a redução do número de folhas na copa, sob condições ambientais 
desfavoráveis, é causada principalmente pela redução no ritmo de emissão foliar e não pela morte precoce da folha.

Os folíolos são cobertos por cutículas espessas, e sob condições adequadas de umidade ficam túrgidos e completamente abertos. Sob condição de déficit hídrico estes se dobram para baixo, interceptando menos energia, diminuindo suas atividades metabólicas. As trocas gasosas com o ambiente e a transpiração ocorrem através dos estômatos, localizados na face inferior dos folíolos do coqueiro. Os estômatos abrem-se durante as horas de maior intensidade luminosa, fechando-se ao entardecer, permanecendo assim durante toda a noite (Passos \& Silva, 1990). Quanto mais abertos estiverem os estômatos, maior será a transpiração, absorvendo assim mais água e nutrientes, aumentando também a entrada de gás carbônico e a atividade fotossintética (Passos, 1997).

A folha tem maior atividade a partir de oito meses após sua emissão, perdurando até sua queda. Sob condições de déficit hídrico as folhas mais ativas são as primeiras a secarem e a caírem, diminuindo assim o metabolismo e a produção de frutos.

\subsubsection{Inflorescência}

O coqueiro é uma planta monóica; logo, possui órgãos sexuais em flores distintas reunidas numa mesma inflorescência paniculada, axilar, protegida por brácteas grandes, chamadas espatas, que ao completar seu desenvolvimento, de três a quatro meses, abrese, libertando a inflorescência, que é formada pelo pedúnculo, espigas e flores femininas e numerosas flores masculinas nos dois terços terminais (Passos, 1997).

Cada folha tem em sua axila um esboço floral que se converterá numa inflorescência frutífera, o que irá depender das condições nutricionais e do clima. Segundo Miranda Júnior (1948), o coqueiro anão emite sua primeira espata com 20 a 28 meses de idade. Após a emissão, a espata leva cerca de dois meses para seu desenvolvimento, quando se abre longitudinalmente e no sentido oposto ao caule, para liberar a inflorescência após 24 horas. 
A primeira inflorescência pode ser constituída de apenas flores masculinas, sendo as femininas produzidas nas inflorescências posteriores. As flores femininas são sésseis e localizam-se na base das espigas. Cada espiga pode conter uma ou mais flores femininas. Freqüentemente apenas um óvulo é fértil (Joly, 1993). Já as masculinas, em grande quantidade, situam-se no ápice das espigas.

O número de flores femininas é fortemente influenciado pelo estado nutricional e hídrico da planta. Sob condições de deficiência hídrica prolongada e/ou desnutrição, poderá não ocorrer desenvolvimento da inflorescência na axila da folha do coqueiro. Contudo, Ohler (1984) enfatiza que as condições de deficiência hídrica ou nutricional podem atrasar os intervalos de florescimento durante anos. O restabelecimento nutricional da planta, nesses casos, irá permitir a reconstituição de seu potencial produtivo. No entanto, isso se dará a longo prazo. Caso a planta sofra essas adversidades no seu crescimento e desenvolvimento inicial, as perdas serão irreparáveis. Mesmo que venha a se proporcionar boas condições de fertilidade, estas plantas produzirão menos que aquelas que não sofreram esse tipo de deficiência (Fremond \& Ouvrier, 1971).

A influência das condições climáticas, de acordo com Fremond et al. (1975), pode proporcionar para uma mesma planta, média mensal de 16,5 a 32,2 flores femininas por inflorescência. Dura em torno de um ano a diferenciação das flores femininas e a abertura da espata e um ano também entre esta e a maturação dos frutos.

No coqueiro anão, as flores masculinas e femininas amadurecem aproximadamente ao mesmo tempo, ocorrendo normalmente a autofecundação (Frémond et al., 1975). No entanto, entre as cultivares do coqueiro anão, o nível de autofecundação é variável e ocorre de acordo com a cultivar considerada.

Em um pomar de coqueiro, as plantas de melhor produtividade não só se caracterizam por um maior número de inflorescência por ano, como também por um maior número de flores femininas por inflorescência (Frémond et al., 1966). Algumas variedades produzem menos flores femininas que outras. Com isso, mantém-se sempre um domínio genético; uma mesma variedade possui grande gama de variações. A influência das condições climáticas tem efeito direto na quantidade de flores femininas por cacho. A diferenciação das flores femininas ocorre de 11 a 12 meses antes da 
abertura da espata, sendo possível relacionar o pequeno número de flores às condições desfavoráveis devido ao estresse hídrico durante os meses em que ocorria a diferenciação (Frémond et al., 1966). As boas condições nutricionais podem aumentar o número de flores femininas por inflorescência (Siqueira et al. 1997).

\subsubsection{Fruto}

O fruto do coqueiro é, botanicamente, uma drupa. Quando completamente desenvolvido apresenta epicarpo, mesocarpo, endocarpo, tegumento e albume. O epicarpo é uma película fina e lisa, envolvendo exteriormente o fruto, quando imaturo. $\mathrm{O}$ mesocarpo é uma camada bastante grossa, fibrosa, conhecida como casca de coco, com espessura variável. O endocarpo é a camada formada pelo material lenhoso e duro, com espessura entre três a seis milímetros. $O$ tegumento reveste $\mathrm{o}$ endosperma caracterizando-se por uma película fina e de cor marrom quando completamente maduro. $\mathrm{O}$ endosperma, conhecido também por albume ou semente é constituído por uma parte sólida e outra líquida. A parte sólida é uma camada branca, do tipo carnoso e espesso conforme a idade do fruto. O endosperma líquido é conhecido como água de coco. Este preenche toda a parte interna do fruto, com função de nutrir a nova planta quando da germinação (Bondar, 1939; Child, 1974; Grimwood, 1977; Ohler, 1984).

Numa primeira fase de formação do fruto tem-se a fase líquida, que acontece lentamente, depois da fecundação, ocorrendo o enchimento do saco embrionário, transformando-se posteriormente na cavidade central, havendo uma formação de deposições pastosas de células que se multiplicam ativamente. A água de coco se encontra no fruto jovem a uma pressão aproximada de $5 \mathrm{~atm}$. Ao final desta etapa, por volta do oitavo mês, começa a se formar o albúmen sólido, tendo um princípio gelatinoso, solidificando-se devido a formação de membranas celulósicas que saem do tegumento seminal (Passos, 1997). 
O coqueiro caracteriza-se pela produção escalonada durante todo ano, com variações estacionais. Em média, são colhidos 14 cachos ao ano para a variedade de coqueiro anão (Passos, 1997).

\subsection{Ecofisiologia da cultura}

O coqueiro anão tem crescimento e produção contínua durante todo o ano, desde que as condições do clima sejam ideais. O coqueiro, sendo uma planta tropical, encontrou no Brasil excelentes condições climáticas para seu pleno desenvolvimento vegetativo e potencial produtivo, o que favoreceu sua expansão em todas as regiões brasileiras (Bondar, 1939). Em locais onde a evapotranspiração é elevada e a distribuição das chuvas é irregular, ocorrem déficits hídricos sazonais que afetam o desenvolvimento e a produção do coqueiro anão.

A área onde o coqueiro é cultivado comercialmente é delimitada pelos trópicos. Porém, em circunstâncias especiais, seu cultivo vai além destes limites. Em condições adversas, o desenvolvimento da cultura em escala comercial encontra sérias restrições. Na região não delimitada pelos trópicos a cultura se desenvolve bem, mas não frutifica satisfatoriamente (Menom \& Pandalai, 1958). Segundo Tammes \& Whitehead (1969), o coqueiro anão frutifica em locais com até $700 \mathrm{~m}$ de altitude. Acima deste valor, na maioria dos casos, podem ocorrer restrições climáticas, o que leva a planta a não produzir.

A pluviosidade é um dos principais fatores climáticos que afeta a produtividade do coqueiro, quando cultivado em sequeiro e sem contribuição do lençol freático (Souza, 1968). A precipitação anual ideal para a cultura é, aproximadamente, $1.500 \mathrm{~mm}$, com valores mensais superiores a $130 \mathrm{~mm}$. Um período de três meses cuja precipitação seja inferior a $50 \mathrm{~mm}$ mensalmente é prejudicial à cultura. Por outro lado, longos períodos chuvosos diminuem a aeração do solo, aumentam a perda de nutrientes por lixiviação e ainda provocam redução da fecundação quando ocorre baixa insolação (Fremond et al., 1975). 
$\mathrm{O}$ coqueiro requer clima quente sem grandes variações de temperatura. $\mathrm{O}$ valor médio anual deve estar em torno de $27^{\circ} \mathrm{C}$, com oscilação de 5 a $7^{\circ} \mathrm{C}$, considerado ótimo para o desenvolvimento da cultura (Child, 1974). A planta responde negativamente ao frio, paralisando seu desenvolvimento, abortando flores femininas e provocando queda de frutos. Temperaturas mínimas diárias inferiores a $15^{\circ} \mathrm{C}$ modificam a morfologia do coqueiro e, mesmo sendo de pequena duração, provocam desordens fisiológicas (Fremond et al., 1975).

O coqueiro é uma planta bastante exigente em luz e não se desenvolve bem sob condições de baixa luminosidade. Insolação de 2.000 horas anuais, com mínimo de 120 horas mensais, é considerada ideal para o pleno desenvolvimento vegetativo e máximo potencial produtivo (Child, 1974). Os estômatos do coqueiro começam a abrir com uma radiação solar entre 200 e $300 \mathrm{~W} \mathrm{~m}^{-2}$ e a abertura máxima é obtida entre 500 e $900 \mathrm{~W} \mathrm{~m}^{-}$ 2 (Passos \& Silva, 1990).

O coqueiro se desenvolve bem em climas quentes e úmidos, não sendo desejável umidade elevada por longo período. Umidade atmosférica elevada reduz a transpiração, a absorção de nutrientes, favorece o desenvolvimento de pragas e doenças na cultura e causa queda de frutos (Child, 1974). A umidade atmosférica adequada situa-se entre 80 a $90 \%$. Os valores mensais não devem ser inferiores a $60 \%$. O vento tem papel importante na disseminação do pólen e na fecundação das flores femininas. Sob condições de déficit hídrico no solo, os ventos fortes são prejudiciais ao desenvolvimento da cultura (Fremond et al., 1975); no entanto, sob condição adequada de umidade, o coqueiro tolera ventos de até $5 \mathrm{~m} \mathrm{~s}^{-1}$.

\subsection{Necessidade hídrica da cultura}

A necessidade de água do coqueiro depende de vários fatores, tais como: a idade da planta (altura e área foliar), requerendo grande quantidade de água durante as fases de desenvolvimento vegetativo e produção, o clima local (radiação solar, temperatura, 
umidade relativa do ar e velocidade do vento), o tipo e o teor de umidade do solo, o método de irrigação utilizado e o estado nutricional da planta (Nogueira et al., 1997), entre outros. Diariamente, a planta pode transpirar cerca de $98 \%$ da água absorvida pelas raízes.

O coqueiro anão, por causa da alta taxa de transpiração, consome mais água que as outras variedades. Nas mesmas condições edafoclimáticas, é o primeiro a apresentar os efeitos do estresse hídrico (IRHO, 1992). A falta d'água reduz o desenvolvimento, prorroga o início da produção por um período de 8 a 24 meses depois de cessado o déficit, e gera frutos de baixa qualidade (São José et al., 1999).

O suprimento adequado de água para a planta mantém um número adequado de folhas e frutos. O processo de crescimento do coqueiro é contínuo. Sendo assim, encontram-se folhas, flores e frutos em vários estádios de desenvolvimento. O déficit de água em qualquer estádio tem como reflexo a redução na produção (Mathew, 1972; Shanmugam, 1973). Segundo São José et al. (1999), muitos elementos constituintes do coqueiro deixam de ser absorvidos na quantidade adequada devido ao déficit hídrico.

O mito de que plantas adultas desenvolvem sistema radicular profundo é, talvez, verdadeiro para explicar o fato delas não morrerem facilmente em condições de seca; mesmo assim, $80 \%$ dos problemas em cultivos de coqueiro anão estão relacionados ao déficit hídrico (Parthasarathy, 1984). Conforme a EMBRAPA (1993), é importante que nos primeiros três anos de vida não haja déficit de água no solo. Quando a escassez é temporária, os sintomas exteriores se tornam pouco evidentes e de constatação difícil. Por outro lado, quando a carência é severa e prolongada, a planta adulta apresenta uma sintomatologia bem característica com queda acentuada de frutos, redução no volume de água e peso de frutos. As folhas velhas, ainda verdes, inclinam, quebram e tendem a se aproximar do estipe. Mesmo durante o dia, as lâminas dos folíolos tendem a fechar. A turgescência dos folíolos diminui muito, provocando enrugamento das lâminas. Em coqueirais jovens ocorre o atraso no crescimento vegetativo.

O clima é o fator preponderante na evapotranspiração da cultura. Todavia, a planta e suas características fisiológicas e de desenvolvimento influenciam na quantidade de água evapotranspirada. Além do clima e da planta, as características 
físicas e químicas do solo, a ocorrência de pragas e doenças, as práticas culturais e o manejo da irrigação utilizados, dentre outros fatores, também podem influenciar no desenvolvimento e na evapotranspiração da cultura (Doorenbos \& Pruitt, 1997).

A variedade de coqueiro-gigante apresenta baixa taxa de transpiração e maior habilidade para conviver com deficiência hídrica no solo, quando comparada com a variedade de coqueiro-anão. Resultados de estudos de campo realizados por Jayasekara \& Jayasekara (1993) mostraram que um coqueiro adulto com 35 folhas (150 $\mathrm{m}^{2}$ de área foliar) transpira de 30 a $120 \mathrm{~L} /$ dia de água, dependendo da demanda evaporativa da atmosfera e do teor de umidade do solo. Estudos realizados em Calicut (Índia), mostraram que a Etc dos coqueiros de 5 anos variou de 2,3 a $5,5 \mathrm{~mm} / \mathrm{dia}$.

A grande maioria dos estudos com relação às necessidades hídricas do coqueiro foram realizadas nas condições de clima e solo da Ásia, utilizando variedades gigantes. No entanto, no Brasil, a maior parte dos plantios irrigados de coqueiro utiliza a variedade Anã, e os estudos a respeito de suas necessidades hídricas encontram-se ainda em fase inicial (EMBRAPA, 2003)

Estudos realizados em Paraipaba no estado do Ceará por Miranda et al. (1998), indicaram, para plantas jovens de coqueiro-anão irrigadas por microaspersão, um consumo de água variando de 8 a 12 litros planta ${ }^{-1}$ ano $^{-1}$ nos primeiros 6 meses após o plantio (com até $10 \%$ da superfície do solo coberta pela cultura), de 12 a 28 litros planta $^{-1}$ ano $^{-1}$ dos 7 aos 12 meses (10\% a 16\% de cobertura do solo), de 30 a 100 litros planta $^{-1}$ ano $^{-1}$ dos 13 aos 24 meses de idade (16\% a 36\% de cobertura do solo) e de 103 a 173 litros planta ${ }^{-1}$ ano $^{-1}$ dos 25 a 36 meses ( $36 \%$ a 64\% de cobertura do solo).

No Brasil, de um modo geral, tem-se utilizado, no cálculo da quantidade de água a ser aplicada na cultura do coqueiro, o fator da cultura $(\mathrm{Kc})$ de 0,8 para plantas adultas (Nogueira et al., 1997). Os resultados obtidos com esse cálculo têm sido satisfatórios. No entanto, deve-se lembrar que esses valores não foram comprovados experimentalmente para as diversas condições ambientais brasileiras, demandando ações de pesquisa específicas para esse fim. É de fundamental importância também monitorar a umidade do solo para verificar a necessidade de ajuste na quantidade de água aplicada (EMBRAPA, 2003). 
Rao (1989) determinou que a evapotranspiração em coqueiros jovens, num oxissolo, em região tropical úmida de Kerala, na Índia, variou de 2,3 a 5,5 mm dia ${ }^{-1}$ e que o coeficiente de cultura $\left(\mathrm{K}_{\mathrm{C}}\right)$ variou entre 0,6 e 0,96, com média igual a 0,82. Nestas condições, a irrigação necessária para a cultura durante os meses de dezembro a maio foi de 122 a 231 litros planta ${ }^{-1}$ dia $^{-1}$.

Jayakumar et al. (1987) utilizaram lisímetro volumétrico para quantificar a evapotranspiração do coqueiro (Cocos nucifera L.) com seis anos de idade em Kerala, Índia. No período de novembro/86 a maio de 1987, a evapotranspiração foi, em média, $3,3 \mathrm{~mm} \mathrm{dia}^{-1}$, com coeficiente de variação de $12 \%$. Neste mesmo período, utilizando as estimativas da evapotranspiração obtidas com os métodos de Penmam-FAO, BlaneyCriddle e tanque Classe $\mathrm{A}$, os autores determinaram que os valores do $\mathrm{Kc}$ foram 0,54 , 0,73 e 0,63 , respectivamente. Os mesmos recomendaram utilizar estes valores no cálculo das necessidades de água do coqueiro durante a estação seca.

Mahesha et al. (1992), em estudo na região costeira da Índia, de clima quente úmido e solo arenoso, determinaram o coeficiente de cultura para coqueiros jovens, em produção, calculados pelo método de Penman modificado. Utilizando avaliações mensais concluíram que, para as condições onde foi realizado o estudo, o valor de Kc deve ser 0,96 .

Chaillard et al. (1983) concluíram que a produtividade da cultura depende do suprimento de água para diferenciação das flores, o que ocorre cerca de dois anos antes dos frutos serem comercializados. A maior demanda ocorre a partir da abertura das espatas até o pleno desenvolvimento do fruto.

No sertão paraibano, produtores de coco estão aplicando, em media, 200 litros de água planta ${ }^{-1} \mathrm{dia}^{-1}$ para atender a elevada demanda de água da cultura, além de realizarem controle fitossanitário e adubações adequadas. Com este manejo estão conseguindo uma produtividade média anual de 160 frutos por planta por ano (Barbosa, 1999). 


\subsection{Manejo da cultura}

$\mathrm{O}$ manejo adequado na cultura do coqueiro visa a atender suas exigências nutricionais, hídricas e fitossanitárias, que são importantes no desenvolvimento e na produção.

A poda de limpeza da copa do coqueiro consiste em eliminar as folhas secas e restos de inflorescência que podem servir de abrigo a pragas. No entanto, as folhas maduras que ainda não secaram devem ser preservadas, porque elas dão a sustentação aos cachos e, ainda, translocam nutrientes remanescentes para as folhas mais novas. Segundo Pereira (1998), é comum retirar a palha e a indúvia, durante a poda de limpeza, recomendando-se sua retirada apenas quando estiver completamente seca e solta.

A cultura do coqueiro deve ser mantida livre de ervas daninhas, por meio de roçagem e coroamento, durante todo o seu ciclo. Estas práticas têm como objetivo principal minimizar a competição por água e nutrientes no solo. A roçagem, embora não afete a estrutura do solo, é uma prática mais indicada para áreas cuja vegetação nativa não exerça grande competição com o coqueiro (Ferreira et al., 1997). O coroamento deve ser realizado em função da infestação de plantas daninhas. Tal prática consiste em eliminar as ervas daninhas na projeção da copa usando-se enxadas ou por intermédio da aplicação de herbicidas. Neste caso, deve-se evitar o contato do herbicida com os frutos, pois este pode causar injúria química na casca e alterar a coloração normal do fruto, prejudicando seu aspecto visual.

Outra opção para a manutenção da limpeza da área destinada ao coqueiral, quanto ao desenvolvimento de ervas daninhas, é o consórcio com animais de pastoreio. A criação em associação com coqueiro é uma prática antiga e muito difundida na maioria das regiões produtoras de coco no mundo. Tradicionalmente, os animais são utilizados como "varredores" ou "roçadores", para manter a vegetação nativa sob controle, diminuindo assim a concorrência entre plantas e os custos com seu controle. Além disso, a produção adicional de carne é considerada complementar ao produto principal, que é o coco (Reynolds, 1981). 
As amostras de solo para análise da fertilidade devem ser coletadas, no mínimo, a cada dois anos na projeção da copa, local das adubações. As amostras devem ser retiradas em duas faixas de profundidades: 0 a 20 e 20 a $40 \mathrm{~cm}$, onde se encontra a maioria das raízes do coqueiro (Cintra et al., 1992). A análise foliar deve ser realizada na mesma época da amostragem do solo, visando otimizar a adubação, evitando-se desperdícios ou falta de nutrientes essenciais, principalmente de micronutrientes. A folha a ser amostrada é a que se localiza no meio da copa, nem muito nova nem muito velha (Sobral, 1997). Ao considerar na amostragem coqueiros adultos, a folha a ser amostrada é a $14^{\mathrm{a}}$, a contar do ápice.

\subsection{Nutrição e adubação do coqueiro}

Para um programa de adubação, torna-se necessário o conhecimento do solo onde está implantada a cultura, aspectos básicos de nutrição, como a remoção, a função e os sintomas de deficiência dos nutrientes, além da dosagem, época, forma e economicidade da adubação (Sobral, 1997). Porém, as recomendações com base em resultados de pesquisas experimentais sobre doses de nutrientes são mais práticas e seguras.

Segundo Ouvrier \& Taffin (1985), a quantidade de fertilizantes por planta deve ser determinada a partir de resultados de experimentos, análises de solo e diagnose foliar, que se baseia no fato de que um aumento na concentração da folha de um determinado elemento ou elementos corresponde a um aumento de produção.

O alerta de diminuição quanto a produtividade de coco proporcionada por fator nutricional procede, pois menos de $1 \%$ das plantações de coco do mundo recebem fertilizantes (Ollagnier \& Wahyuni, 1984), apesar dos resultados de experimentos importantes, bastante convincentes quanto ao aumento da produção, demonstrando haver retorno econômico com o uso da adubação. 
A condição nutricional do coqueiro é importante para a produção de frutos. A quantidade de nutrientes extraídos pela cultura poderá atingir valores elevados, considerando-se que a produtividade pode situar-se entre 150 a 250 frutos por planta por ano a partir do $3^{\circ}$ ano de produção ( $5^{\circ}$ ano de cultivo). A planta sob deficiência nutricional diminui o número de flores femininas por espata e terá dificuldades em manter a fecundação e os frutos formados, causando queda prematura dos mesmos. Verifica-se também que o índice de pegamento de frutos diminui após uma produção abundante, como conseqüência da exaustão nutricional da planta (Gomes, 1992; Medina et al., 1980). Esse fenômeno se explica pelo fato de que naturalmente os frutos deveriam ser tirados depois de completada sua maturação, o que nesse caso não ocorre.

Em cultivo de sequeiro ou irrigado, a adubação é uma das práticas de expressivo impacto na produtividade do coqueiro. Segundo Kiehl (1999), a correção da fertilidade do solo com aplicações conjuntas de NPK e esterco promoveram aumento na produção do coqueiro, provavelmente devido ao efeito associado do fósforo e do esterco. Desta forma, a adubação com esterco é recomendada e sua composição deve ser levada em conta no cálculo da adubação química. $\mathrm{O}$ adubo orgânico tem a vantagem de atuar como um fertilizante de liberação lenta, fornecendo nutrientes de forma contínua, melhorando as condições físicas e biológicas do solo na projeção da copa.

\subsection{Níveis críticos de nutrição}

Vários estudos com a variedade gigante e material híbrido foram empreendidos para determinar a quantidade de nutrientes extraídos pelo coqueiro.

A diagnose foliar fornece os níveis de macronutrientes e micronutrientes na folha amostrada, para verificar como os teores dos nutrientes estão em relação aos níveis críticos (Tabela 1 e 2), auxiliando na interpretação dos resultados da análise do solo e, conseqüentemente, numa reposição nutricional mais adequada. 
Tabela 1. Níveis críticos de macronutrientes na matéria seca da folha intermediária do coqueiro anão em estádio de produção

\begin{tabular}{|c|c|c|c|c|c|c|c|c|c|c|}
\hline $\mathrm{N}$ & & $\mathrm{F}$ & K & $\mathrm{Ca}$ & $\mathrm{g}$ & M & $\mathrm{a}$ & $\mathrm{N}$ & ${ }_{1}^{C}$ & $\mathrm{~S}$ \\
\hline ----- & & 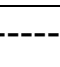 & 列 & $----\mathrm{g} \mathrm{kg}$ & 20 & & - & & & -- \\
\hline$-20^{*}$ &, $2^{*}$ & 1 & $5-10^{*}$ & $-3,0^{1,5}$ & $0^{*}$ & 3, &, $0^{* *}$ & 2 & $-5,5^{* *}$ & $2,0^{* *}$ \\
\hline
\end{tabular}

Fonte: ${ }^{*}$ Kanapathy (1971) citado por Camboim Neto (2002), ${ }^{* *}$ Manciot et al. (1979).

Tabela 2. Níveis críticos de micronutrientes na matéria seca da folha intermediária do coqueiro anão em estádio de produção

\begin{tabular}{|c|c|c|c|c|}
\hline Fé & $\mathrm{Mn}$ & $\mathrm{Zn}$ & B & $\mathrm{Cu}$ \\
\hline $40^{*}$ & $100^{*}$ & $15^{* *}$ & $10^{* *}$ & $4-5^{* *}$ \\
\hline $\begin{array}{r}\text { Fonte: }{ }^{*} \text { Kanap } \\
\text { al. (198 }\end{array}$ & & & Esch & \\
\hline
\end{tabular}

Segundo Malavolta et al. (1974), o coqueiro requer solos profundos, bem drenados e adubação equilibrada. Afirma ainda que a adubação organomineral no coqueiro, além de melhorar certas características físico-químicas notadamente a capacidade de troca, também facilita a retenção de umidade e o desenvolvimento de radicelas na superfície do solo.

\subsubsection{Nitrogênio no coqueiro}

O nitrogênio é indispensável na fisiologia das plantas. É utilizado na síntese de aminoácidos, proteínas, ácidos nucléicos, sendo também necessário para a molécula de 
clorofila e enzimas (Malavolta, 1976). A deficiência do nitrogênio afeta toda a fisiologia do coqueiro e provoca queda na produção de frutos

O teor de nitrogênio na folha $\mathrm{n}^{\mathrm{o}} 14$, considerado ideal, situa-se na faixa de 1,8 2,0\% de $\mathrm{N}$ para as variedades gigantes e de 1,8-2,2\% em média para os híbridos. Abaixo deste valor, a nutrição em $\mathrm{N}$ fica comprometida, o que pode, segundo Manciot et al. (1980), levar a planta a exteriorizar os seguintes sintomas de deficiência: a) num primeiro estádio, há um leve e contínuo amarelecimento das folhas mais baixas da planta; b) num estádio mais avançado, as folhas jovens da copa tornam-se verde pálido, dando aos folíolos uma aparência opaca; a intensa descoloração das folhas velhas pode torná-las amarelo dourado uniforme, muitos cachos abortam e o número de flores femininas por inflorescências é reduzido; c) num último estádio, a planta parece ser afetada por uma espécie de raquitismo, conforme vai crescendo, o caule estreita-se gradualmente até ficar com aspecto de "ponta de lápis", o número e o tamanho das folhas da coroa foliar são reduzidos.

Manciot et al. (1980) relata três fatores que influenciam na deficiência de $\mathrm{N}$ na planta: i) Quando não irrigada, chuvas escassas ou mal distribuídas influenciam os níveis de $\mathrm{N}$, reduzindo o tempo de nitrificação e o prolongamento da atividade do sistema de absorção das raízes, como acontece em determinadas áreas do litoral nordestino: segundo Medina et al. (1980), em levantamento efetuado em áreas produtoras de coco, $78 \%$ delas apresentavam carência de nitrogênio. Esta informação foi comprovada por Sobral (1987), segundo o qual 86,5\% dos pomares desde o Sul da Bahia até o Ceará, apresentam teor de $\mathrm{N}$ da diagnose foliar menor que 1,8\%; ii) Condições desfavoráveis do solo à mineralização da matéria orgânica, fato comum nos solos de coral, lixiviados por um lençol freático muito alto, como também em solos calcários e hidromórficos, arenosos lixiviados, muito pobres em matéria orgânica; iii) Manutenção errada do solo, estimulando o crescimento de gramíneas, fortes consumidoras de nitrogênio, causando um desequilíbrio na nutrição nitrogenada.

Em vários experimentos realizados no oeste africano, Ollagnier \& Wahyuni (1984) estudaram o efeito da nutrição nitrogenada, utilizando o $\mathrm{N}$ na forma de uréia, não 
constatando efeito na produção em termos de números de cocos. $\mathrm{O}$ único efeito observado ocorreu na experiência onde o solo era extremamente saturado, sem cobertura verde. Efeitos benéficos foram observados no crescimento e na precocidade do desenvolvimento do estipe.

$\mathrm{Na}$ Malásia, uma boa reposta à fertilização nitrogenada foi obtida por Thye et al. (1971) em solos argilosos plantados com anão vermelho, registrando desenvolvimento vegetativo melhor (comprimento e área foliar), aumento no número de nozes, mas baixa quantidade de copra noz ${ }^{-1}$. Apesar disso, o balanço foi positivo com um aumento de $26 \%$ de copra árvore ${ }^{-1}$ ano $^{-1}$. Esta mesma conclusão foi defendida por Muliyan \& Nelliat (1971), quando doses crescentes de nitrogênio proporcionaram aumento do número de frutos em detrimento da diminuição na quantidade de copra $\operatorname{coco}^{-1}$.

IRHO (1989) confirma a ação significativa da adubação nitrogenada no crescimento e desenvolvimento dos coqueiros jovens no tocante ao maior diâmetro do coleto.

Há uma estreita relação entre os níveis de $\mathrm{N}$ e os de outros nutrientes. A ação da fertilização nitrogenada pode ser subordinada à nutrição potássica. Para baixo conteúdo de $\mathrm{K}$, o sulfato de amônia reduz o número de $\operatorname{cocos}$ e de copra $\operatorname{coco}^{-1}$, mas tão logo a deficiência de $\mathrm{K}$ seja corrigida, o $\mathrm{N}$ favorece o número de cocos, porém o baixo efeito na relação copra noz ${ }^{-1}$ persiste (Manciot et al., 1980). Já Ollagnier \& Ochs (1973), estudando a interação N-K, concluíram que a ausência de uma interação clara pode ser a conseqüencia de um pequeno número de deficiência de $\mathrm{N}$ e uma leve ação do $\mathrm{K}$ no metabolismo de N. Estes autores também levaram em consideração que o uso de um material vegetal mais produtivo terá uma influência considerável sobre as exigências de $\mathrm{N}$ e trará à luz sinais de interação. 


\subsubsection{Potássio no coqueiro}

O potássio desempenha um papel importante na fisiologia da planta, intervém no metabolismo e aceleração dos movimentos estomáticos. É importante na ativação de enzimas, na translocação de açúcares e na divisão celular (Malavolta, 1976).

A elevação da concentração de $\mathrm{K}$ na folha é acompanhada de uma melhoria de todos os fatores de produção (Medina et al., 1980). Trabalhos (IRHO, 1989) mostraram que a aplicação dos nutrientes potássio e magnésio foi benéfica sobre o número de cocos, e na quantidade de copra $\operatorname{coco}^{-1}$, apresentando uma interação positiva dos dois nutrientes sobre a produção.

Os níveis de potássio influenciam fortemente a produção (Coomans, 1975), principalmente na variedade anão que produz bem mais que o material gigante. De acordo com Manciot et al. (1980), trabalhando com híbridos, a nutrição com potássio aumentou significativamente o desenvolvimento da planta, começando pela largura do coleto e o número de inflorescências emitidas pela árvore.

Os sintomas visuais de deficiência se caracterizam por manchas ferruginosas de diâmetro bastante irregular, variando de 0,5 a 4,0 $\mathrm{mm}$ nos dois lados dos folíolos, acentuando-se nas extremidades, e chegando à necrose (Ollivier, 1993a). Posteriormente, a planta apresenta um amarelecimento das folhas do meio da copa e culmina com secamento das folhas baixas. De acordo com o mesmo autor, os sintomas de deficiência se manifestam quando o teor foliar, em potássio, é menor que $0,5 \%$.

As causas da deficiência em potássio são geralmente de ordem pedológica, uma vez que normalmente os solos não possuem as quantidades necessárias de $\mathrm{K}$ que o coqueiro necessita. Porém, mesmo em áreas onde o conteúdo natural de $\mathrm{K}$ é alto (acima de $0,30 \mathrm{meq} / 100 \mathrm{~g}$ ), este conteúdo inicial pode ser comprometido por exaustivas colheitas (Manciot et al., 1980).

Os efeitos do potássio são muito visíveis nos solos de baixa fertilidade. Em experimentos implantados pelo IRHO (1989), as respostas ao K foram imediatas e 
altamente significativas se manifestando em todos os fatores de produção. Neste mesmo trabalho, quando desenvolvido sobre areia litorânea, foi confirmada a ação altamente significativa da adubação potássica na produção, alertando também que os danos ocasionados às plantas pela carência de $\mathrm{K}$ durante os primeiros anos de plantio são irreversíveis. As plantas que recebem $\mathrm{K}$ anualmente produzem sempre mais do que aquelas que só recebem o nutriente quando adultas (Fremond \& Ouvrier, 1971).

Experiências têm mostrado o antagonismo entre $\mathrm{K}-\mathrm{Ca}$, $\mathrm{K}-\mathrm{Mg}$ e $\mathrm{K}-\mathrm{Na}$, no entanto, a relação K-Mg é mais divergente do que as outras. Coomans (1977) observou que a deficiência de $\mathrm{Mg}$ era induzida nos híbridos pela fertilização com K. Entretanto, a adubação com $\mathrm{Mg}$ não teve efeito nos níveis de $\mathrm{K}$ na folha.

\subsection{Fertirrigação}

Testes de campo têm indicado que o aumento da produtividade gerado pela fertirrigação compensa os seus custos de investimento e manejo do sistema, tornando maior a rentabilidade do empreendimento. A fertirrigação oferece vantagens a quem a utiliza, como também, incorpora mais tecnologia, abandonando a utilização de práticas de manejo baseadas apenas na análise visual e experiência prática com os cultivos tradicionais de outras variedades. Entretanto, a expansão dessa atividade agrícola vem acontecendo sem um respaldo técnico-científico, pela carência de resultados de pesquisa em nossas condições. Pode-se dizer que isso ocorreu devido a antecipação da técnica em relação a pesquisa.

A aplicação de fertilizantes simultaneamente com a água de irrigação constitui um avanço na agricultura irrigada, requerendo maior capacitação de técnicos e agricultores; seu uso está relacionado a uma série de vantagens econômicas quando comparadas com os métodos tradicionais de adubação (Vivancos, 1993).

Pode-se utilizar qualquer método ou sistema de irrigação para aplicar fertilizantes, todavia, os pressurizados são os mais apropriados. O princípio de aplicação 
da fertirrigação preconiza o uso de fertilizantes solúveis em água e equipamentos específicos para injetar a solução nas linhas de irrigação. Para determinar as quantidades corretas de fertilizantes, é necessário considerar a análise de solo, da água de irrigação e foliar, bem como a extração de nutrientes pelas raízes (Raij, 1991). Porém, as recomendações com base em resultados de pesquisas experimentais sobre doses de nutrientes são mais práticas e seguras.

São inúmeras as vantagens do uso da fertirrigação, sendo uma das maiores virtudes, a possibilidade da aplicação dos nutrientes recomendados de maneira parcelada, segundo a marcha de absorção da cultura nos seus diferentes estádios (Sousa \& Sousa, 1998). Aplicações de fertilizantes mais freqüentes e em menores quantidades permitem reduzir as perdas de nutrientes, tornando-se bem evidente sua eficiência para o nitrogênio, principalmente em solos de textura arenosa que facilitam a sua lixiviação.

O movimento de íons está relacionado com a intensidade de percolação e com o comportamento de cada um em relação às condições de fixação e adsorção, que é função de cada íon e do tipo de solo em que se encontra. Quando se trata de solo arenoso, o uso da fertirrigação e o controle da concentração de nutrientes na solução do solo são mais complexos, reivindicando maior parcelamento e diminuição da concentração principalmente na aplicação de $\mathrm{N}$ e $\mathrm{K}$, que se perdem com maior facilidade por lixiviação.

Segundo Malavolta et al. (1997), o processo de absorção se dá quando o elemento químico passa do substrato para uma parte qualquer da célula. Para que esse elemento penetre na raiz, é necessário primeiramente o contato com a mesma, havendo três processos para o contato: intercepção radicular, fluxo de massa e difusão. O fluxo de massa consiste no movimento do elemento na solução do solo por diferença de potenciais de umidade, ou seja, de um maior para um menor potencial. Já o processo de difusão se caracteriza pelo movimento espontâneo do elemento químico causado pela agitação térmica a favor do gradiente de concentração, ou seja, da solução do solo para a raiz. 
$\mathrm{O}$ nitrogênio, na forma de nitrato $\left(\mathrm{NO}_{3}{ }^{-}\right)$, é o nutriente de maior mobilidade no solo. O movimento de nitrato no solo é aproximadamente proporcional ao movimento da água que percola (Burt et al., 1998). Portanto, além de se quantificarem níveis adequados de água e nitrogênio, é necessário conhecer a magnitude e a velocidade das transformações desse nutriente no solo (Coelho, 1994).

O potássio é um nutriente absorvido da solução do solo pelas raízes, predominando o contato pelo processo de difusão. Contudo, a aplicação de doses relativamente altas desse nutriente pode causar movimentação no solo pelo fluxo de massa, principalmente em regiões tropicais e subtropicais (Malavolta, 1980).

A fertirrigação, utilizando o método de microaspersão em frutíferas que tenham sistema radicular fasciculado, como no caso do coqueiro, em solo arenoso, permite um menor potencial de lixiviação dos nutrientes em relação ao gotejamento devido ao rápido movimento vertical do fluxo de massa apresentado nesse sistema. No caso de solos arenosos cultivados por fruteiras, a microaspersão é mais recomendada. Esse comportamento, mostra a estreita relação com a dinâmica de água, havendo uma predominância de expansão lateral para os solos argilosos e vertical para solos arenosos, dentro da zona de saturação do bulbo úmido (PAR/CSCI, 1999).

Portanto, em solos arenosos é necessária uma área de umedecimento mais ampla, a fim de proporcionar melhor distribuição de água e fertilizantes para as raízes, diminuindo as perdas por percolação profunda. Isso se reflete com mais evidência no uso de uma maior freqüência de aplicação de água e nutriente.

O manejo inadequado da água no solo traz sérios problemas relacionados a perdas de nutrientes, principalmente por lixiviação. Rice et al. (1986) menciona que o fluxo de água por drenagem profunda deve variar bastante devido ao tipo de solo, à aplicação desuniforme de água, às alterações nas propriedades do solo durante o desenvolvimento da cultura e à qualidade da água aplicada. Analisando a redistribuição de água em solos arenosos, sob irrigação por gotejamento, Souza et al. (1992) verificaram que o fluxo de água no solo na vertical cresceu sensivelmente com o aumento do volume de água aplicado. 


\section{MATERIAL E MÉTODOS}

\subsection{Localização e caracterização da área experimental}

O experimento foi conduzido no Campo Experimental do Jiqui, pertencente a Empresa de Pesquisa Agropecuária do Rio Grande do Norte (EMPARN), localizado no município de Parnamirim-RN, situado nas coordenadas geográficas de $5^{\circ} 46^{\prime}$ de Latitude Sul e $35^{\circ} 12^{\prime}$ de Longitude Oeste a $18 \mathrm{~m}$ de altitude. A estrutura experimental (Figura 1) era provida de energia elétrica e de abastecimento de água proveniente da Lagoa do Jiqui.

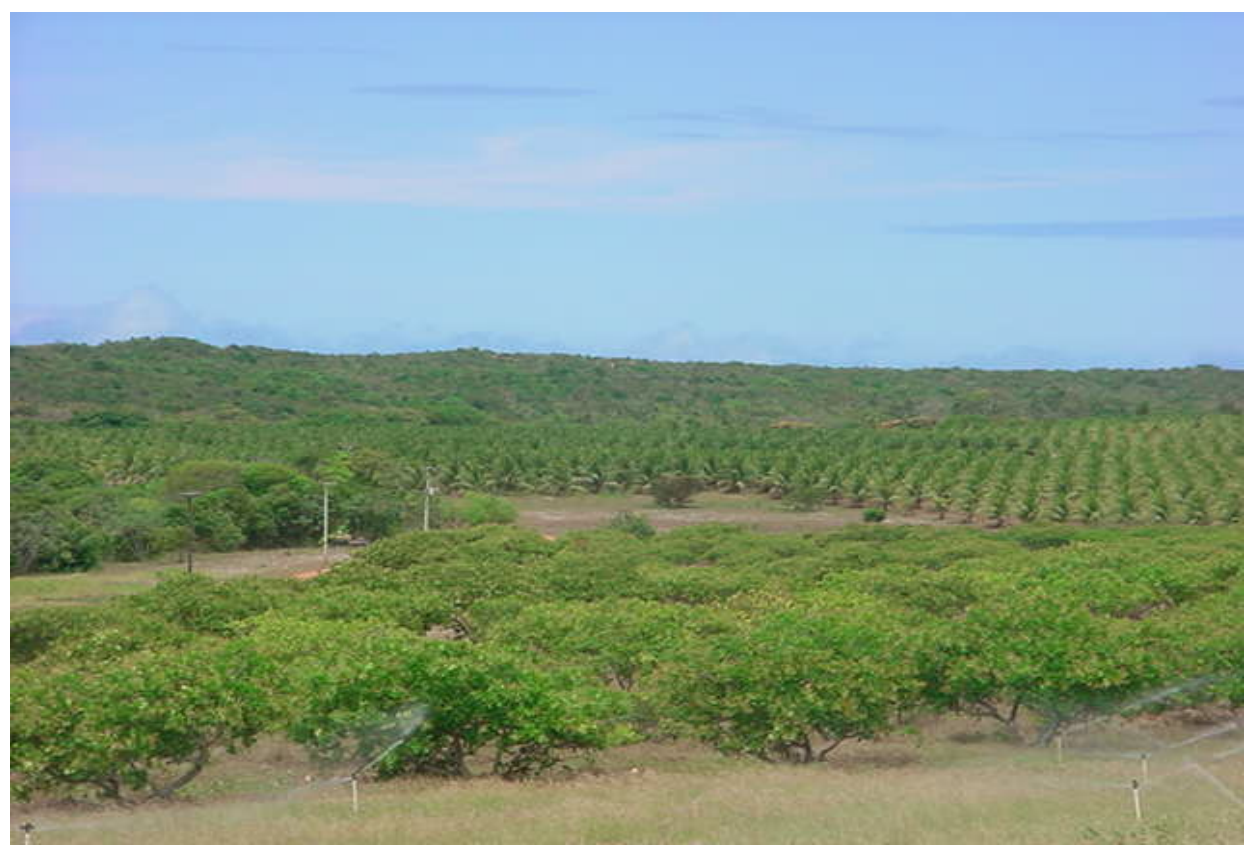

Figura 1 - Vista geral do Campo Experimental do Jiqui 
Segundo a classificação de Wilhelm Köppen, o clima da região é do tipo As', ou seja, tropical chuvoso com verão seco e estação chuvosa se adiantando para o outono, temperatura média anual de $28^{\circ} \mathrm{C}$ e precipitação média anual variando de 1500 a 1800 $\mathrm{mm}$.

O relevo da área experimental é caracterizado como plano. O pomar havia sido implantado há seis anos em solo classificado como neosolo quartzarênico, cujas características físico-hídricas, segundo a EMBRAPA (1997), são apresentadas na Tabela 3.

Tabela 3. Características* físico-hídricas do solo na área experimental

\begin{tabular}{|c|c|c|c|c|c|c|c|}
\hline \multirow{3}{*}{$\begin{array}{l}\text { Prof. } \\
(\mathrm{cm}) \\
0-20\end{array}$} & \multicolumn{3}{|c|}{ Granulometria $\left(\mathrm{g} \mathrm{kg}^{-1}\right)$} & \multirow{2}{*}{$\begin{array}{c}\text { Classe } \\
\text { Textural }\end{array}$} & C.C. & PMP & \multirow{2}{*}{$\begin{array}{c}\mathrm{Dg} \\
\left(\mathrm{g} \mathrm{cm}^{-3}\right)\end{array}$} \\
\hline & Areia & Silte & Argila & & \multicolumn{2}{|c|}{-----(\%)----- } & \\
\hline & 956 & 43 & 1 & Arenoso & 50 & 10 & 1,6 \\
\hline $20-40$ & 957 & 42 & 1 & Arenoso & 40 & 10 & 1,6 \\
\hline
\end{tabular}

Este experimento deu continuidade a linha de pesquisa ${ }^{a}$ sobre regime de fertirrigação iniciada 2 anos antes (abril de 2000 a março de 2002). Firmou-se a partir daí o ensaio, conduzido até março de 2004, exatamente em mesma área experimental e em mesmo delineamento estatístico. Houve uma diferenciação entre parcelas experimentais com relação às suas características químicas, proporcionadas pelas doses de fertirrigação testadas anteriormente. Essa diferenciação foi devida à variabilidade dos tratamentos empregados. Quanto às características físicas não se detectaram diferenças aparentes.

$\mathrm{Na}$ pesquisa anterior (abril de 2000 a março de 2002), as doses de nitrogênio (na forma de uréia) e potássio (na forma de cloreto de potássio) utilizadas foram exatamente $50 \%$ menores em relação aos tratamentos testados neste ensaio. Na Tabela 4, são apresentados a caracterização química do solo sob cultivo comercial em junho de 2000 e posteriormente em março de 2002, sob influência da pesquisa com fertirrigação,

\footnotetext{
${ }^{\text {a }}$ Entre abril de 2000 a março de 2002 esta área experimental serviu ao trabalho de Tese do Doutorando Ricardo Alencar da Silva / CCA - UFPB.
} 
mostrando o conteúdo residual de fertilidade, com influência das doses de fertilizantes testadas sob fertirrigação.

Os tratamentos com doses de fertilizantes deram início a partir do $6^{\circ}$ ano de cultivo dando-se continuidade até o $7^{\circ}$ ano. A estabilização de produção, quando a cultura atinge o máximo de exploração de potencial produtivo, se dá de forma evolutiva durante estes dois anos. Partindo-se daí verificou-se a influência das dosagens de adubação dos tratamentos sob as variáveis de produção, qualidade de fruto $\mathrm{e}$ desenvolvimento vegetativo para o $6^{\circ}$ e $7^{\circ}$ ano de cultivo.

Tabela 4. Características químicas do solo, sob cultivo comercial em junho de 2000 e sob influência da pesquisa com fertirrigação em março de 2002, na área experimental

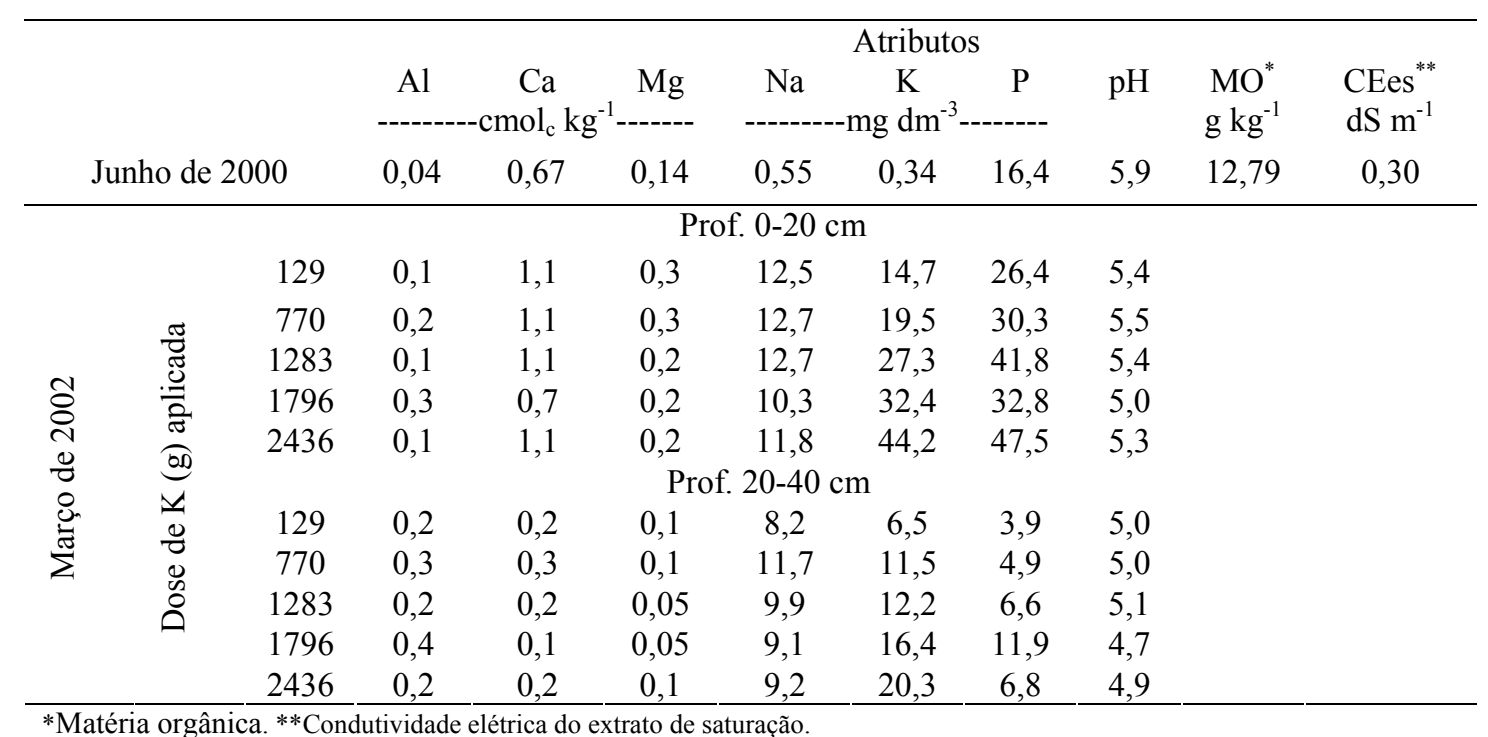

\subsection{Tratamentos e delineamento experimental}

O delineamento estatístico adotado foi o de blocos inteiramente casualizados, com 4 repetições, utilizando para composição dos tratamentos a matriz experimental Plan Puebla III, sendo compostos da combinação de dois fatores: doses de nitrogênio e 
potássio via fertirrigação, nas formas de uréia e cloreto de potássio, respectivamente, obtendo-se 10 tratamentos.

As matrizes Plan Puebla foram criadas baseadas nos princípios dos Centrais Compostos (Turrent e Laird, 1980) existindo três variações (I, II e III) que dependem da forma como se definem as doses dos tratamentos. Neste caso utilizou-se a matriz Plan Puebla III que tem 5 níveis. Para definir os tratamentos, inicialmente estabeleceu-se os espaços experimentais, dentro dos quais foram selecionadas as doses de cada fator. Leite (1984) sugere utilizar -0,9 e 0,9 em lugar de -1 e 1 . O limite superior correspondeu à dose mínima das quais se tem resposta na literatura. $\mathrm{O}$ limite inferior para cada fator foi a dose mínima de interesse prático. Existe ainda, um nível central (0) que define uma dose média entre os limites, como também as demais doses em função dos níveis fixados $( \pm 0,4 ; \pm 0,9)$. Portanto, a matriz Plan Puebla III assim modificada ficou da seguinte forma: $2^{\mathrm{k}}+2 \mathrm{k}+1+1$. Os níveis de doses para o caso de $\mathrm{N}$ e de $\mathrm{K}$ referentes aos tratamentos estão apresentados na Tabela 5.

Tabela 5. Tratamentos e suas respectivas doses de $\mathrm{N}$ e K, na forma de uréia e cloreto de potássio, aplicadas durante o ano ${ }^{1}$ e por evento ${ }^{2}$ de fertirrigação

\begin{tabular}{|c|c|c|c|c|c|c|c|c|}
\hline \multirow{3}{*}{ Tratamento } & \multirow{2}{*}{\multicolumn{2}{|c|}{ Níveis }} & \multicolumn{6}{|c|}{ Doses } \\
\hline & & & $\mathrm{N}^{1}$ & $\mathrm{~K}^{1}$ & Uréia $^{1}$ & $\mathrm{KCl}^{1}$ & Uréia $^{2}$ & $\mathrm{KCl}^{2}$ \\
\hline & A & B & & & 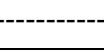 & 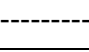 & & \\
\hline 1 & $-0,4$ & $-0,4$ & 1540 & 1539 & 3420 & 2565 & 2632 & 1972 \\
\hline 2 & $-0,4$ & 0,4 & 1540 & 3591 & 3420 & 5985 & 2632 & 4604 \\
\hline 3 & 0,4 & $-0,4$ & 3591 & 1539 & 7980 & 2565 & 6140 & 1972 \\
\hline 4 & 0,4 & 0,4 & 3591 & 3591 & 7980 & 5985 & 6140 & 4604 \\
\hline 5 & $-0,9$ & $-0,4$ & 256 & 1539 & 570 & 2565 & 440 & 1972 \\
\hline 6 & 0,9 & 0,4 & 4874 & 3591 & 10830 & 5985 & 8332 & 4604 \\
\hline 7 & $-0,4$ & $-0,9$ & 1540 & 258 & 3420 & 430 & 2632 & 332 \\
\hline 8 & 0,4 & 0,9 & 3591 & 4872 & 7890 & 8120 & 6140 & 6248 \\
\hline 9 & 0,0 & 0,0 & 2565 & 2565 & 5700 & 4275 & 4384 & 3288 \\
\hline 10 & $-0,9$ & $-0,9$ & 256 & 258 & 570 & 430 & 440 & 332 \\
\hline
\end{tabular}

${ }^{1}$ Quantidade planta/ano. ${ }^{2}$ Quantidade por evento de fertirrigação para 40 plantas. 
A área útil foi composta por 200 plantas distribuídas em 1,6 ha com parcelas formadas por 10 plantas, sendo destas 5 plantas úteis, e uma bordadura externa circundando o experimento. Na Figura 2, está representado o croqui experimental, de acordo com a disposição das plantas nas parcelas por cada tratamento, escolhidas na área do experimento.

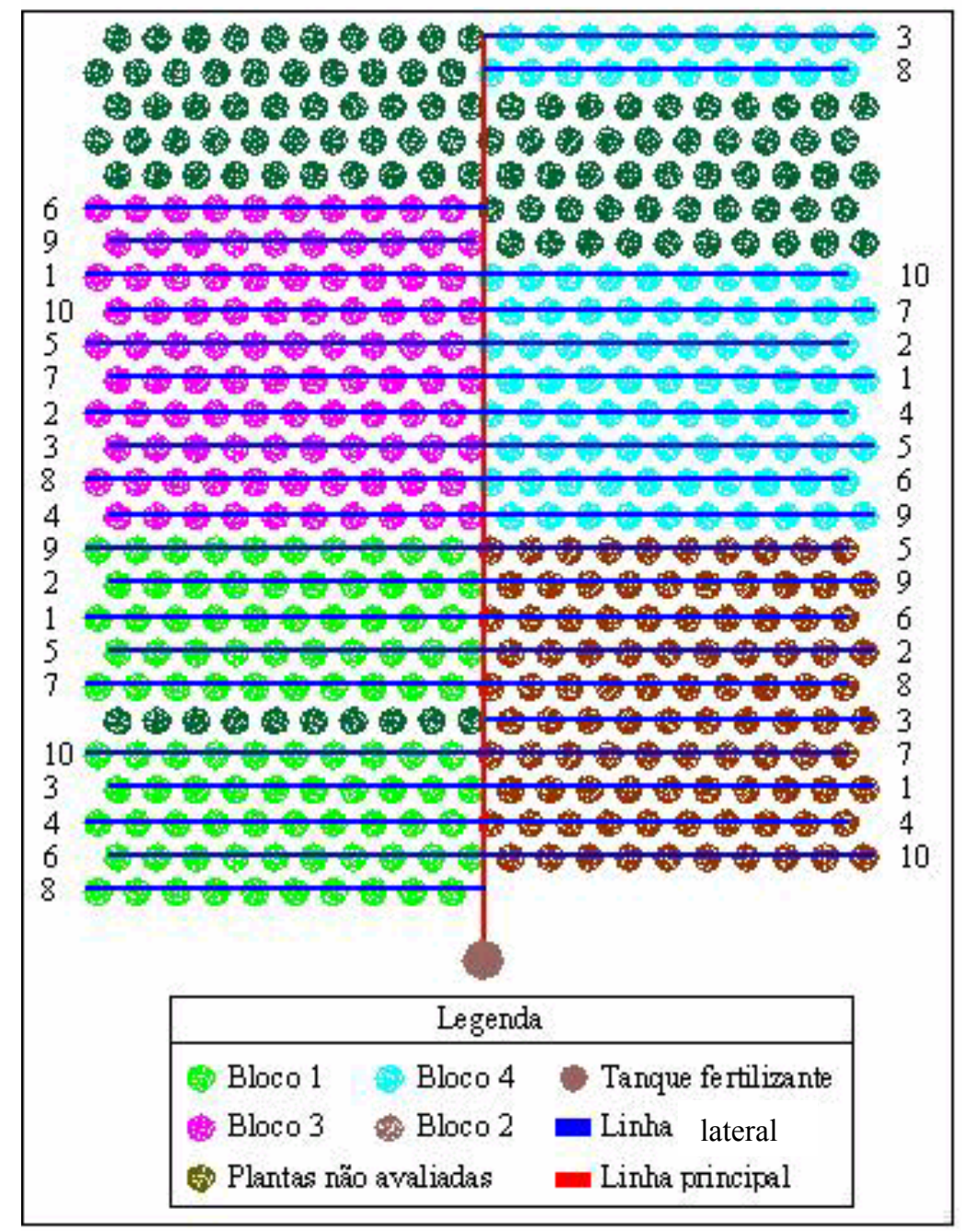

Figura 2 -Disposição das plantas escolhidas na área experimental 


\subsection{Condução do experimento}

\subsubsection{Sistema e manejo da irrigação}

O conjunto motobomba elétrico era composto de uma bomba $\mathrm{KSB}^{\circledR}$ modelo 40200 , rotor $201 \mathrm{~mm}, 3500 \mathrm{rpm}$, acoplado por luva elástica a um motor $\mathrm{WEG}^{\circledR}$ de $25 \mathrm{CV}$.

Utilizou-se microaspersores Rondo autocompensantes, de bocal verde e diâmetro de orifício de 1,4 mm, com vazão nominal de $53 \mathrm{~L} \mathrm{~h}^{-1}$, os quais operaram à pressão de $150 \mathrm{kPa}$, proporcionando um raio molhado de $3,2 \mathrm{~m}$. Cada planta dispunha ao lado, de um emissor, num total de 10 microaspersores por linha lateral montados ao longo das linhas de plantio, colocados a $50 \mathrm{~cm}$ de distância em posição paralela ao estipe. A tubulação das linhas laterais é de polietileno de baixa densidade, com diâmetro externo de $16 \mathrm{~mm}$ e interno de $13 \mathrm{~mm}$. Destinou-se este sistema de irrigação para aplicação das dosagens de fertirrigação, possibilitando a aplicação diferenciada para cada parcela (Figura 2). Na entrada de cada parcela (linha lateral) foi colocado um registro de globo. Esta montagem permitiu que os tratamentos fossem isolados, a fim de permitir a entrada de fertilizantes somente nas linhas laterais desejadas. Realizou-se tratamentos de limpeza dos bocais periodicamente a cada 2 meses, com uma solução a base de hipoclorito de sódio $(\mathrm{NaClO})$, com $12 \%$ de cloro livre. Deu-se preferência a microaspersão em vez do gotejo, devido ao fato do solo ser essencialmente arenoso, sob pena de não haver a formação mínima necessária do bulbo úmido para o bom desenvolvimento do sistema radicular do coqueiro.

Para avaliação dos microaspersores foi adotada uma parcela completa do sistema de irrigação. Este sistema foi avaliado, no início e a partir daí a cada 6 meses, quanto às suas características de uniformidade de emissão (UE) de água pelo método PatternEfficiency (Pinto et al., 1991). Foi utilizada a amostragem padrão para UE, que prevê a medição de vazões em 16 emissores tomados em pontos previamente determinados da área avaliada, sendo 4 emissores por lateral, para um total de 4 laterais assim distribuídas: primeira lateral da linha de derivação, lateral a 1/3 do comprimento da linha de derivação, lateral a 2/3 do comprimento da linha de derivação e última lateral. 
Os emissores de cada lateral foram escolhidos segundo o mesmo critério de distribuição: primeiro emissor, emissor a $1 / 3$ do comprimento da lateral, emissor a $2 / 3$ da lateral e último emissor da lateral. Na medida das vazões foi utilizada uma proveta de plástico, com capacidade de $1000 \mathrm{~mL}$, graduada de $10 \mathrm{em} 10 \mathrm{~mL}$. O tempo de coleta da vazão foi de 60 segundos, controlado por cronômetro analógico. Durante esse período de 60 segundos, o microaspersor foi inserido dentro da proveta, de forma que não houvesse respingos para fora da mesma. Foram medidas as pressões inicial e final de cada lateral após o término da coleta de vazões de seus emissores. O cálculo de UE foi feito pela equação seguinte:

$$
U E=\frac{\bar{\chi}_{25}}{\bar{X}} \cdot 100
$$

em que:

$\overline{\mathrm{X}_{25}}=$ média dos $25 \%$ do total de valores coletados, com os menores valores $(\mathrm{ml})$;

$\overline{\mathrm{X}}=$ média de todos os valores coletados $(\mathrm{ml})$.

O uso de fertirrigação impõe procedimentos criteriosos. Cadahía (2001) orienta, como primeiro passo para dimensionar a solução de fertilizante, dispor de uma análise confiável da composição da água de irrigação. A água utilizada na irrigação foi proveniente da lagoa do Jiqui, sendo classificada como $\mathrm{C}_{1} \mathrm{~S}_{1}$ (Ayers \& Westcot, 1991) após caracterização química realizada pelo Laboratório de Irrigação e Salinidade da Universidade Federal de Campina Grande (UFCG), que é apresentada na Tabela 6.

Tabela 6. Características químicas da água utilizada na irrigação do coqueiro

\begin{tabular}{|c|c|c|c|c|c|c|c|c|c|c|}
\hline \multirow{3}{*}{$\mathrm{pH}$} & \multirow{3}{*}{$\begin{array}{c}\text { RAS } \\
\left(\mathrm{m} \mathrm{mol} \mathrm{L}^{-1}\right)^{0,5}\end{array}$} & \multirow{3}{*}{$\begin{array}{c}\mathrm{CE} \\
\mathrm{dS} \mathrm{m}^{-1}\end{array}$} & \multicolumn{4}{|c|}{ Cátions } & \multicolumn{4}{|c|}{ Ânions } \\
\hline & & & $\mathrm{Ca}$ & $\mathrm{Mg}$ & $\mathrm{Na}$ & K & $\mathrm{HCO}_{3}$ & $\mathrm{CO}_{3}$ & $\mathrm{Cl}$ & $\mathrm{SO}_{4}$ \\
\hline & & & --- & $----m$ & $\mathrm{ol}_{\mathrm{c}} \mathrm{L}^{-1}$ & ----- & 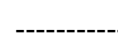 & $---m$ mo & $L^{-1}-$ & \\
\hline 6,35 & 0,83 & 0,22 & 0,85 & 1,22 & 0,86 & 0,21 & 1,24 & Ausente & 2,3 & Ausente \\
\hline
\end{tabular}

A irrigação obedecia a uma freqüência diária, pela manhã, durante todo o período de estudo, suspensa apenas nos dias em que ocorriam precipitações superiores a $10 \mathrm{~mm}$. 
Caracterizou-se a demanda hídrica atmosférica da região a partir de estimativas realizadas com base na temperatura do ar, insolação, umidade relativa do ar e velocidade do vento.

O volume de irrigação aplicado no coqueiro foi estimado a partir da evapotranpiração de referência (ETo) calculada pelo modelo de Penman-Montheith (Allen et al., 1998). O valor do coeficiente de cultivo (Kc) adotado para o coqueiro foi igual a 1,0, devido a experiências realizadas na área revelar uma melhor correlação climática com o uso deste valor. Este coeficiente não sofreu variação durante o experimento; isso porquê as plantas apresentavam desenvolvimento vegetativo e produção constantes. No Brasil, de modo geral, tem-se utilizado, no cálculo da quantidade de água aplicada no cultivo do coqueiro, o Kc de 0,8 para plantas adultas (Nogueira et al., 1997) ressaltando a peculiaridade de cada ambiente climático para o ajustamento desse fartor.

\subsubsection{Aplicação dos fertilizantes}

No início do experimento foi incorporado calcário dolomítico $\left(2 \mathrm{Mg} \mathrm{ha}^{-1}\right)$ e gesso (200 $\mathrm{kg} \mathrm{ha}^{-1}$ ) aplicados a lanço em toda área (incluindo entrelinhas), com o objetivo de corrigir os problemas de acidez e elevar as concentrações de $\mathrm{Ca}$ e $\mathrm{Mg}$.. As aplicações de fósforo, cálcio, magnésio, enxofre, zinco, cobre, boro e manganês foram mantidas na mesma quantidade durante a fase de produção. A cada 6 meses houve um parcelamento da adubação de cobertura, incorporando ao solo na área de atuação das raízes, $60 \mathrm{~L}$ de esterco de curral, $2 \mathrm{~kg}$ de FOSMAG-464 ${ }^{\circledR}$, composto químico a base de fósforo, com a seguinte composição (\%): $\mathrm{P}_{2} \mathrm{O}_{5}=18,0, \mathrm{Ca}=14,0, \mathrm{Mg}=3,5, \mathrm{~S}=0,0, \mathrm{Zn}=0,65, \mathrm{~B}=$ 0,15 e $\mathrm{Cu}=0,18$, além de $300 \mathrm{~g}_{\text {planta }}{ }^{-1}$ de "FTE BR - 12", composto químico a base de micronutrientes com a seguinte composição (\%): $\mathrm{Zn}=9,00, \mathrm{~B}=1,80, \mathrm{Cu}=0,8, \mathrm{Mn}=$ $2,00, \mathrm{Fé}=3,00$ e $\mathrm{Mo}=0,10$.

A fertirrigação foi realizada com o auxílio de uma bomba centrífuga, injetora de fertilizantes, modelo BC-92AV 1CV, de marca SCHENEIDER ${ }^{\circledR}$. A quantidade de nutriente foi divida em 52 aplicações durante cada ano do experimento, correspondendo 
às semanas de cultivo do ensaio. As dosagens de $\mathrm{N}$ e $\mathrm{K}$, na forma de uréia e cloreto de potássio, foram aplicadas de acordo com os tratamentos estabelecidos. Seguiram uma freqüência semanal, fertirrigando-se diariamente dois tratamentos e completando-se as 10 aplicações na área em 5 dias, ou seja, dois tratamentos por dia. De acordo com o programado para o tratamento (Tabela 5), a solução foi preparada diluindo-se cada quantidade em 100 L d'água com antecedência à fertirrigação, mexendo-se e deixandose em repouso por um período de 20 minutos. Após este procedimento a solução foi bombeada para o sistema de irrigação. Adotou-se o tempo de fertirrigação de 30 minutos (Frizone et al., 1985).

É necessária que se mantenha a fertilidade do solo constante durante a fase de estabilização de produção do coqueiro devido à manutenção e produção de folhas, flores e frutos que se apresentam nos diferentes estádios na planta.

Estes níveis possibilitaram verificar os efeitos da adubação no crescimento, desenvolvimento, produção e qualidade do coco verde em várias concentrações iônicas da solução do solo.

\subsubsection{Cultura}

Utilizou-se plantas de coqueiro pertencentes à variedade anã, sub-variedade verde do Jiqui, espaçadas em formação triangular 7,5 x 7,5 x 7,5m, iniciando o sexto ano de cultivo em fase de estabilização de produção. A planta nesta fase atinge sua maturidade fisiológica, expressando por completo seu potencial produtivo.

O cultivar coqueiro anão do Jiqui, apresenta crescimento lento. Reproduz-se por auto-fecundação, é mais precoce e produz um grande número de frutos, de forma contínua durante todo período produtivo, sendo colhidos de 12 a 16 cachos por planta por ano, num intervalo de 21 a 30 dias. Em cada cacho pode-se ter de 15 a 20 frutos (Bondar, 1939; Miranda Júnior, 1948; Ohler, 1984; Gomes, 1992). Anualmente, em condições ideais, o coqueiro emite de 12 a 16 folhas mantendo, em média, 25 a 28 folhas na copa com uma vida útil de um ano e meio a dois anos (Bondar, 1939; Ohler, 1984). 


\subsubsection{Tratos culturais e fitossanitários}

O controle de ervas daninhas foi feito utilizando roçagem e gradagem mecânica, coroamento manual sub-copa a cada dois meses, bem como utilizando-se de consorcio com carneiros, subdividindo-se a área em piquetes para pastejo. Para contenção dos animais nos piquetes, utilizou-se cerca elétrica com três fios de arame distanciados 25 cm entre si a partir da superfície do solo.

Houve a necessidade do controle preventivo do ácaro da necrose do coqueiro (Eriophyes guerreronis), gorgulho dos frutos e flores (Parissoschemus obsulus) e traça dos coqueiros novos (Hyalospila ptychsis) que causam grandes danos. Para tanto, utilizou-se de uma solução a base de óleo vegetal de algodão (1,5 \%) e detergente neutro (1,0\%), fazendo-se pulverizações periódicas a cada 21 dias, e também um monitoramento sistemático na identificação de possíveis infestações. Utilizou-se iscas atrativas contendo ferormônio, roletes de cana de açucar, melaço e benomil na captura e eliminação do Rhynchophorus palmarum, vetor da doença do "anel vermelho".

\subsubsection{Colheita}

Como a produção se destina ao consumo de água de coco, os frutos foram colhidos verdes, aproximadamente com 7 meses de idade, a partir da abertura da inflorescência. As colheitas se deram em todos os meses, desde o primeiro mês de estudo, num intervalo de $21 \mathrm{em} 21$ dias a partir da primeira colheita, prolongando-se por um período de 2 anos.

\subsection{Variáveis avaliadas}

\subsubsection{Desenvolvimento vegetativo}

Avaliou-se a altura do caule, a circunferência da estipe, o diâmetro da copa e o número de folhas. 


\subsubsection{Altura do estipe}

A altura do estipe foi medida do nível do solo até o ponto de inserção das folhas no estipe, observando-se a influência da adubação na altura do estipe para duas épocas, chuvosa (junho de 2003) e seca (dezembro de 2003). Essa determinação se correlaciona diretamente com a quantidade de folhas emitidas e posteriormente cenescentes, dando idéia do desenvolvimento e do estádio vegetativo da planta.

\subsubsection{Circunferência do estipe}

A circunferência do caule foi medida em três plantas dentro de cada parcela, com o auxílio de uma trena a 1,0m do nível do solo, analisando a porção do estipe desenvolvido com possíveis diferenças no seu diâmetro, em decorrência de variações no tamanho individual das células, já que não ocorre crescimento radial do estipe. Portanto, dado a variação de dosagens de adubação, tendo-se controlado outros aspectos como a umidade ou a ataque de pragas e doenças, a circunferência do estipe torna-se um indicativo do vigor nutricional das plantas.

\subsubsection{Diâmetro sombreado de projeção da copa}

A partir de medidas do diâmetro de projeção da copa sobre o solo ao meio dia, foi medida em três plantas úteis por repetição a área ocupada e, conseqüentemente, inferiu-se seu potencial fotossintético para cada dosagem de adubação, sendo utilizada essa medida também, na estimativa do potencial evaporativo da planta.

\subsubsection{Emissão foliar}

Observou-se a influência da adubação na quantidade de folhas emitidas. Realizou-se a contagem da quantidade de folhas por planta observando para cada período amostrado o total e a manutenção da quantidade de folhas por copa, em três plantas por repetição. 


\subsubsection{Variáveis de produção}

\subsubsection{Florescimento}

O acompanhamento sistemático de abertura de inflorescências emitidas, se deu a partir do $6^{\circ}$ mês de estudo, feito diariamente em três plantas por repetição, anotando-se a data e numerando-se a folha de origem para diferenciar a idade entre cachos. Após a identificação de abertura da inflorescência, realizava-se a contagem manual do total de flores femininas. Com as datas de emissão, calculou-se o intervalo de tempo (dias) para emissão de inflorescência.

\subsubsection{Produção}

Os frutos com idade de colheita ideal para consumo da água-de-coco, ainda verdes, com sete meses após a abertura completa da inflorescência, eram colhidos em um intervalo de 21 dias. Quantificou-se o número de frutos e peso médio dos frutos. Após cada colheita foram retirados, aleatoriamente, dois frutos representativos por parcela em cada tratamento, para pesagens individuais e medição do volume de água de coco.

\subsubsection{Qualidade da produção}

O fruto de coco verde ainda não sofreu uma padronização quanto às suas características morfológicas visuais e de palatabilidade. Sendo assim, todos os frutos colhidos foram contabilizados, salvo exceção daqueles com severos ataques de pragas ou doenças. Após cada colheita retirava-se, do total colhido, aleatoriamente uma amostra (dois frutos) por tratamento e por repetição, dando um total de 8 frutos por tratamento. Feitas as pesagens individuais, procedia-se a abertura dos frutos, determinando-se para água de coco o volume, o $\mathrm{pH}$, a condutividade elétrica $(\mathrm{CE})$ e o teor de sólido solúveis TSS ( $\left({ }^{\circ}\right.$ Brix) (Ferreira Neto et al., 2002). 
Para determinação do ${ }^{\circ}$ Brix, utilizou-se um refratômetro de bolso manual. A CE e o $\mathrm{pH}$ foram medidos diretamente em condutivímetro e peagâmetro, respectivamente.

\subsubsection{Estado nutricional da planta}

A avaliação do estado nutricional da planta foi feita por intermédio de amostras da folha 14, contando-se a partir do ápice, por ser uma folha do meio da copa do coqueiro, nem muito nova nem muito velha. De um modo prático, pôde-se identificar a folha 14 observando-se a inflorescência que se encontrava na eminência da abertura (folha $\mathrm{n}^{\circ}$ 9), abaixo da qual está a folha $\mathrm{n}^{\circ} 14$ que possui na maioria das vezes, na sua axila, um cacho com frutos do tamanho de uma mão fechada (punho).

A coleta foi realizada em duas plantas por parcela, coletadas ao final do primeiro ano experimental e 6 meses depois (período seco e chuvoso, respectivamente); de setembro de 2003 a janeiro de 2004 se fez um acompanhamento mensal. A identificação e preparação da amostra se deram seguindo metodologia descrita por Sobral (1997).

Nas amostras, foram determinados os seguintes elementos: P, N, K, Ca, S, B, Na, $\mathrm{Zn}, \mathrm{Cu}, \mathrm{Fe}$ e $\mathrm{Mn}$. O N foi determinado pelo método do micro-Kjedahl. Após digestão nitroperclórica; o P foi determinado pelo método colorimétrico do azul de molibdato. O $\mathrm{K}$ e $\mathrm{Na}$ por espectrofotometria de emissão. $\mathrm{O} \mathrm{Ca}, \mathrm{Mg}, \mathrm{Zn}, \mathrm{Cu}, \mathrm{Fe}$ e $\mathrm{Mn}$ por espectrofotometria de absorção atômica. Em alíquota do digerido, o enxofre foi determinado pelo método do sulfato de bário. O cloro por titulação potenciométrica com $\mathrm{AgNO}_{3}$ e o boro por colorimetria, pelo método da curcumina (Malavolta, 1976).

\subsubsection{Fertilidade do solo}

Amostras simples de solo com quatro repetições por tratamento, foram coletadas em abril e dezembro de 2002; em junho e dezembro de 2003, na área de influência do microaspersor, a $1 \mathrm{~m}$ de distância do tronco nas profundidades de $0-5 \mathrm{~cm}, 0-20 \mathrm{~cm}$ e 20 $40 \mathrm{~cm}$. O objetivo da coleta até os $5 \mathrm{~cm}$ de profundidade foi o de avaliar a dinâmica do nutriente no solo sob fertirrigação, podendo servir de comparativo para as proporções de 
nutriente nas duas primeiras camadas. Nas referidas amostras foram determinados os teores de $\mathrm{P}, \mathrm{K}, \mathrm{Ca}, \mathrm{Mg}, \mathrm{Zn}, \mathrm{Cu}$, Fé e o $\mathrm{Mn}$. O fósforo foi extraído pelo método Mehlich1 e determinado por colorimetria pelo método de azul do molibdato. A extração do K, $\mathrm{Ca}$ e $\mathrm{Mg}$ se deu com solução de $1 \mathrm{~N}$ de acetato de amônio, sendo determinados, o primeiro, por espectrofotometria de emissão e os outros dois por absorção atômica. $\mathrm{O}$ $\mathrm{Zn}, \mathrm{Cu}, \mathrm{Fe}$ e $\mathrm{Mg}$ foram extraídos com solução de Mehlich 1 e determinados por absorção atômica. As análises foram realizadas pelo Laboratório de Água, Solo e Planta da EMPARN.

\subsubsection{Processamento de dados e parâmetros avaliados}

As análises estatísticas foram realizadas utilizando-se o procedimento dos modelos lineares generalizados do SAS. Os efeitos dos diferentes níveis de N e K sobre as variáveis medidas na planta e no solo foram avaliados por superfície de resposta e pelos métodos convencionais da análise de variância (teste F), aplicando-se o teste de regressão polinomial de segunda ordem para os casos em que ocorreu efeito significativo, conforme recomenda Nogueira et al. (1997).

As comparações entre os nutrientes disponíveis no solo em diferentes profundidades, foram realizadas pelo teste t para dados pareados (Steel \& Torrie, 1980). Os valores medidos foram submetidos ao teste de regressão linear, analisando-se também os valores de $r^{2}$. 


\section{RESULTADOS E DISCUSSÃO}

\subsection{Características meteorológicas do período de cultivo experimental}

$\mathrm{O}$ coqueiro requer clima quente sem grandes variações de temperatura. Durante o período experimental, altas temperaturas foram observadas (Figura 3), com máximas de $34,6^{\circ} \mathrm{C}$ e mínimas de $20,2^{\circ} \mathrm{C}$ para os dois anos do ensaio. A temperatura média variou de $23,3^{\circ} \mathrm{C}$ a $29,5^{\circ} \mathrm{C}$ e de $23,7^{\circ} \mathrm{C}$ a $30,5^{\circ} \mathrm{C}$, com médias de $26,7^{\circ} \mathrm{C}$ e $28,3^{\circ} \mathrm{C}$ para o primeiro e segundo ano de ensaios, respectivamente. Nos dois períodos de cultivo experimental os dados mostram uma tendência uniforme, revelando uma caracterização climática bem definida. Isso favorece o planejamento do cultivo comercial, principalmente quando se faz uso da irrigação e fertirrigação.

(A)

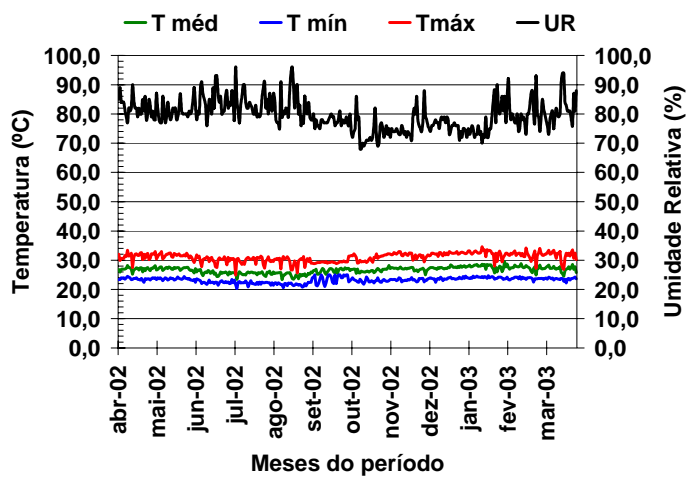

(B)

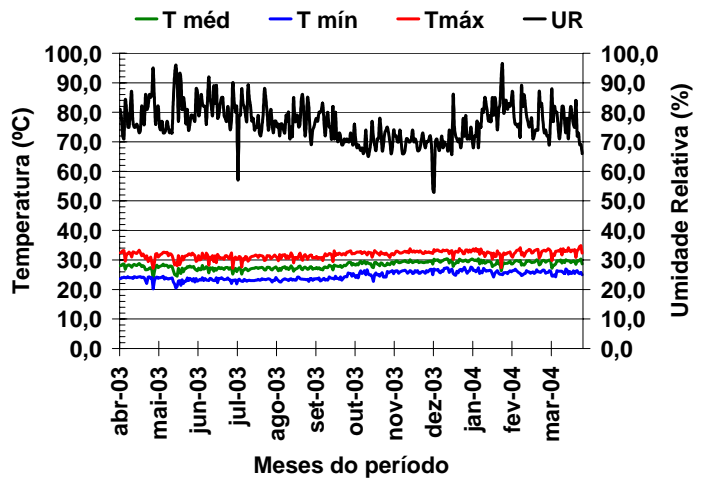

Figura 3 - Variação das temperaturas máxima, média e mínima e umidade relativa média do ar durante o período de abril de 2002 a março de 2003 (A) e de abril de 2003 a março de 2004 (B) 
Os resultados são considerados satisfatórios para o desenvolvimento da cultura. Segundo Child (1974), o valor da temperatura média anual deve permanecer em torno de $27^{\circ} \mathrm{C}$, oscilando de 5 a $7^{\circ} \mathrm{C}$. O coqueiro, conduzido nessa faixa de temperatura, encontrou um ambiente climático favorável ao seu pleno desenvolvimento vegetativo e potencial produtivo, não ocorrendo o risco de haver paralisação de seu desenvolvimento, abortamento de flores femininas e queda de frutos. Isso favorece sua expansão na região Nordeste do Brasil. Temperaturas mínimas diárias inferiores a $15^{\circ} \mathrm{C}$ modificam a morfologia do coqueiro e, mesmo sendo de pequena duração, provocam desordens fisiológicas (Fremond et al., 1975). Child (1974) observou que o número de frutos por planta, o tamanho da noz e a quantidade de copra por noz são consideravelmente afetados até 30 meses após um prolongado período de estiagem, sendo que a recuperação da produção só se dá 2 anos após o fim desse período. Excesso de chuva por um longo período pode ser prejudicial e causar redução de insolação, falta de aeração do solo, lixiviação de fertilizantes e diminuição na taxa de fecundação. Contudo, o uso da irrigação bem manejada conciliada com boa drenabilidade do solo é a forma mais segura de cultivo do coqueiro.

A umidade relativa média do ar (Figura 3) variou de $68 \%$ a $96 \%$ e de $53 \%$ a $96 \%$ no primeiro e segundo ano, respectivamente. Valores de UR inferiores a 60\%, prejudicam o desenvolvimento do coqueiro (Ochs, 1977). A planta também sofre em condições de UR muito elevada devido a propagação de doenças fúngicas e redução na absorção de nutrientes, ocasionando queda prematura dos frutos (Menon \& Paladai, 1958).

A evapotranspiração de referência (ETo) variou de 1,55 a 6,02 $\mathrm{mm} \mathrm{d}^{-1}$ e de 1,68 a 7,62 $\mathrm{mm} \mathrm{d}^{-1}$, com média de 4,33 e 4,86 $\mathrm{mm} \mathrm{d}^{-1}$ (Figura $4 \mathrm{~A}$ ) para o primeiro e segundo ano de ensaios, respectivamente. A estação chuvosa na região teve início no mês de janeiro com final em agosto, atingindo um acumulado acima de $1600 \mathrm{~mm}$ em cada ano (Figura 4 B); entretanto, com uma distribuição de chuva bastante irregular, que foi estrategicamente controlada mediante às irrigações. Tem-se observado que o crescimento e a produção não dependem apenas da pluviosidade total, mas também da distribuição anual das chuvas (Passos, 2003). A precipitação pluviométrica adequada 
situa-se em torno de $1500 \mathrm{~mm}$ anuais, todavia com pluviosidades mensais nunca inferiores a $130 \mathrm{~mm}$ (Fremond et al., 1975).

Há uma tendência de aumento da ETo e redução da UR ao longo do ano, o que se deve à ocorrência de baixa precipitação pluviométrica durante os meses de julho a dezembro.

A influência das condições climáticas tem efeito direto na produção, na quantidade de flores femininas por cacho. Pela caracterização climática definida durante os períodos de ensaio experimental, acredita-se que a taxa fotossintética tenha sido alta, embora seja uma planta $C_{3}$ e não existam dados específicos para o coqueiro por se desenvolver em regiões quentes (Castro \& Kluge, 2001).

(A)

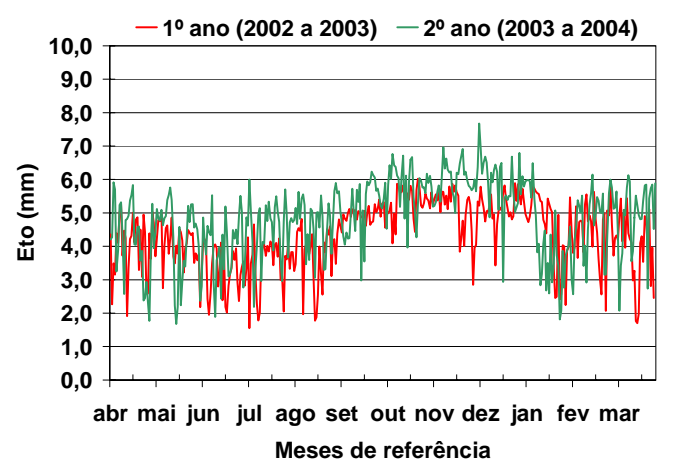

(B)

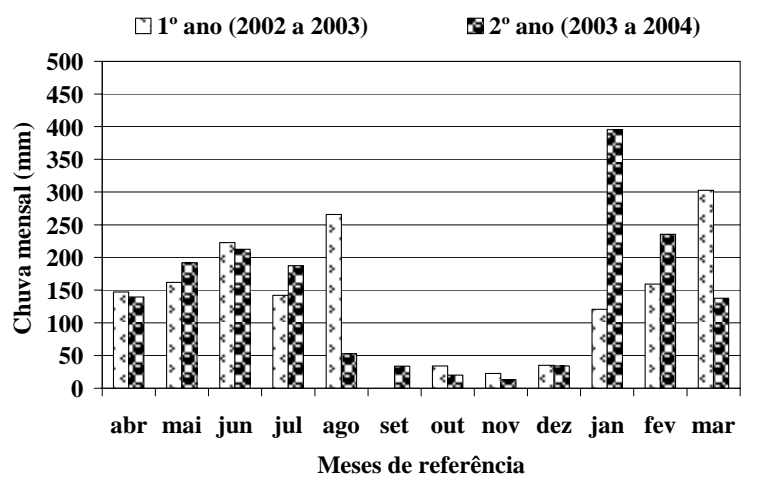

Figura 4 - Variação da evapotranspiração de referência (A) e chuvas mensais (B) durante o período de abril de 2002 a março de 2003 (A) e de abril de 2003 a março de 2004 (B)

\subsection{Avaliação do sistema de irrigação}

O ensaio de avaliação do sistema de irrigação revelou que o sistema apresentava alta uniformidade de aplicação de água. O sistema apresentou alta uniformidade de aplicação, ficando acima de $90 \%$ de eficiência (93\%, 91\% e 92\%). Portanto, o sistema de irrigação apresentou performance satisfatória, podendo-se afirmar que as variações de 
vazão encontradas nos emissores não exerceram efeito significativo na aplicação da irrigação e dos tratamentos.

\subsection{Desenvolvimento Vegetativo}

A altura do estipe não sofreu influência das doses de $\mathrm{N}$ e também das interações entre $\mathrm{N}$ e K. Apresentou variação em relação às doses de potássio. Entretanto este efeito se mostrou significativo $(\mathrm{P} \leq 0,10)$ apenas na época de estiagem (dezembro de 2003). Na Figura 5, verifica-se comportamento quadrático da curva do período chuvoso e do período de estiagem representado as alturas médias do estipe em relação às doses de potássio aplicadas. Child (1974) descreve que o crescimento em altura, para o coqueiro gigante, está em função das condições edafoclimáticas e da idade do coqueiro, sendo observado um crescimento mais rápido na fase jovem.

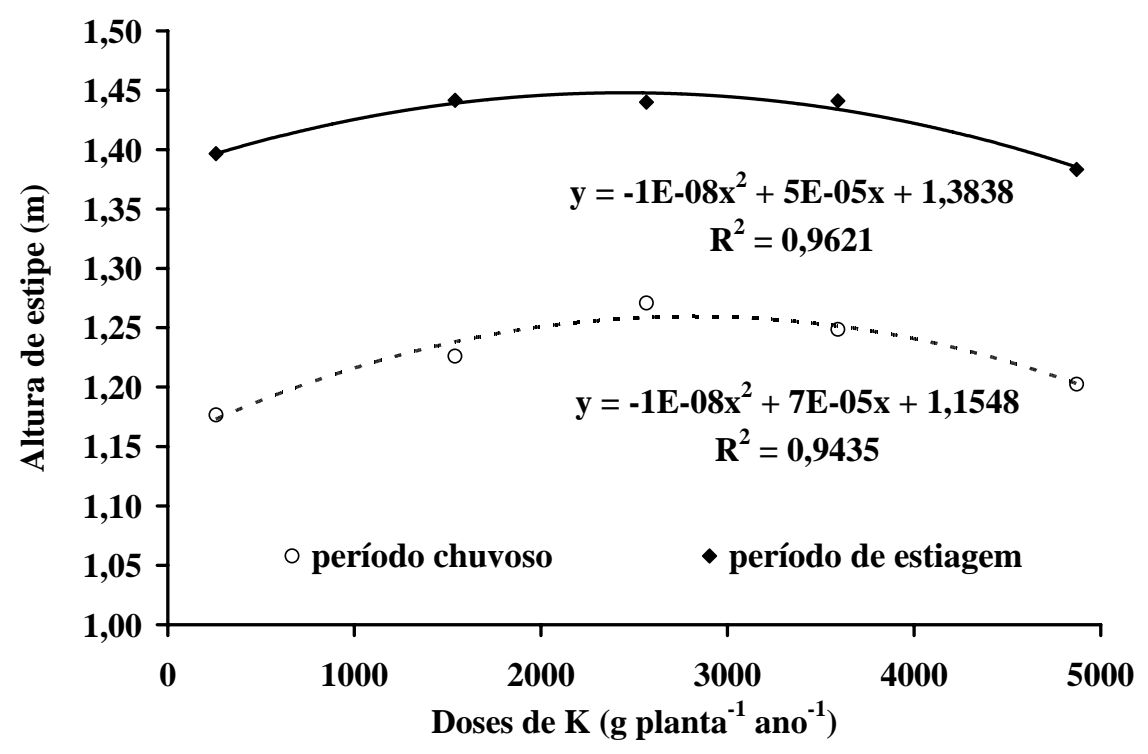

Figura 5 - Altura do estipe durante o período chuvoso (junho de 2003) e de estiagem (dezembro de 2003) em função de doses de potássio 
A idade das plantas é a mesma para todo o pomar, portanto as condições edafoclimáticas interagiram com os tratamentos de forma a pronunciar diferenças de altura de estipe no período de estiagem. Observa-se que houve um maior crescimento $(0,22 \mathrm{~m})$ do estipe até $2565 \mathrm{~g}$ planta $^{-1}$ ano $^{-1}$ de potássio e que as doses superiores não proporcionaram aumentos no desenvolvimento do estipe durante o intervalo das avaliações. Isto se explica pelo fato do período chuvoso ter favorecido ao desenvolvimento naqueles tratamentos, o que se constata no período de estiagem.

O perímetro do estipe sofreu significativo efeito das doses de $\mathrm{N}(\mathrm{P} \leq 0,05)$ e $\mathrm{K}$ $(\mathrm{P} \leq 0,01)$ sem que fosse verificado interação entre elas. Observa-se pela superfície de resposta da Figura 6, que as doses de $\mathrm{K}$ tiveram efeito no aumento do perímetro o que não ocorreu em relação às doses de $\mathrm{N}$. Este fato é comprovado pela maior curvatura $\mathrm{e}$ descendência da linha do fator "doses de N". A análise de correlação $\left(\mathrm{r}^{2}=0,89 ; \mathrm{P} \leq 0,05\right)$ também confirma este efeito depressivo, mostrando que o perímetro do estipe foi menor quando se elevou as doses de $\mathrm{N}$ na fertirrigação.

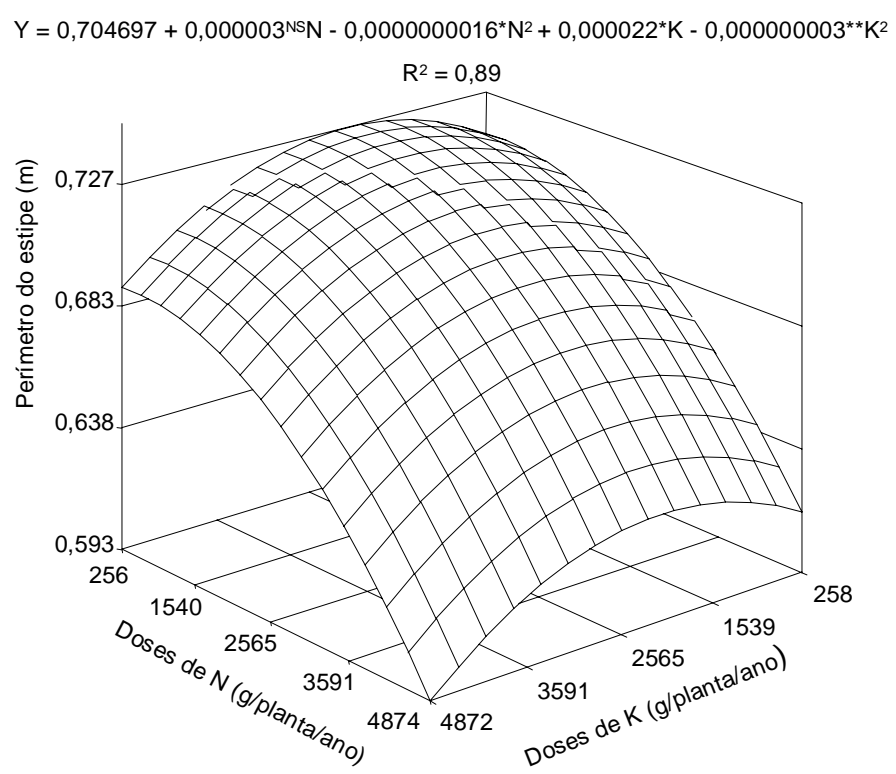

Figura 6 - Superfície de resposta relacionando o perímetro do estipe do coqueiro com doses de potássio e nitrogênio 
A dose de $\mathrm{K}$ que promoveu maior diâmetro $(0,73 \mathrm{~m})$ de estipe enconcentra-se em torno de $2180 \mathrm{~g} \mathrm{planta}^{-1}$ ano $^{-1}$, à medida que se diminui a dosagem de nitrogênio no solo. O desenvolvimento do vigor do estipe do coqueiro pode ser constatado antes mesmo de seu pronunciamento do solo, por meio de determinações do perímetro do coleto (tufo de folhas). $\mathrm{O}$ estipe não apresenta crescimento secundário, ou seja, em expansão, em virtude da ausência de tecido meristemático. O aumento da espessura é limitado e não há, em geral, formação de novos tecidos, e sim um aumento no tamanho individual de suas células. Sob condições desfavoráveis como seca prolongada, má nutrição ou ataque de pragas e doenças, a porção do estipe desenvolvido neste período pode apresentar variações no seu diâmetro, reduzindo-o, em decorrência de variações no tamanho individual das células (Child, 1974). O coqueiro anão verde do Jiqui tem se destacado quanto ao melhor desempenho deste atributo dentre os demais cultivares da variedade Anão (Ramos et al., 2004). Estes autores revelam não haver interação, nas condições de estudo, entre a época e as variáveis altura de planta e diâmetro do coleto.

Os períodos, chuvoso e de estiagem, tiveram variações quanto ao número de folhas vivas em todos os tratamentos analisados. Durante o período chuvoso as plantas apresentaram uma menor quantidade média de folhas em relação ao período de estiagem, com uma diferença média em torno de 7 folhas de um período a outro. Isso possivelmente se deve à maior umidade relativa (UR) do período, potencializando a incidência e proliferação de doenças fúngicas como a "seca das folhas". O nitrogênio quando é assimilado pela planta em grandes quantidades, pode propiciar maior fragilidade à membrana plasmática facilitando com isso a entrada de patógenos. As observações de Leite \& Encarnação (2002) contrastam com as do presente trabalho, pois os mesmos revelam não ter havido diferenças entre os períodos de chuva e de estiagem quanto ao número de folhas mortas e também que durante o período chuvoso a emissão de folhas teve maior freqüência.

$\mathrm{Na}$ avaliação do número de folhas vivas no período chuvoso encontrou-se efeito quadrático (Figura $7 \mathrm{~A}$ ) e significativo $(\mathrm{P} \leq 0,10)$ para o $\mathrm{K}$ revelando uma tendência de aumento dessa variável vegetativa. Porém quando se avaliou este parâmetro na época de 
estiagem encontrou-se efeito quadrático e significativo $(\mathrm{P} \leq 0,05)$ das doses de $\mathrm{N}$, tendo pequeno acréscimo na quantidade de folhas sendo comprovado pela a constância da superfície de resposta (Figura 7 B) das doses de $\mathrm{K}$ em condições de baixa dose de $\mathrm{N}$.

A

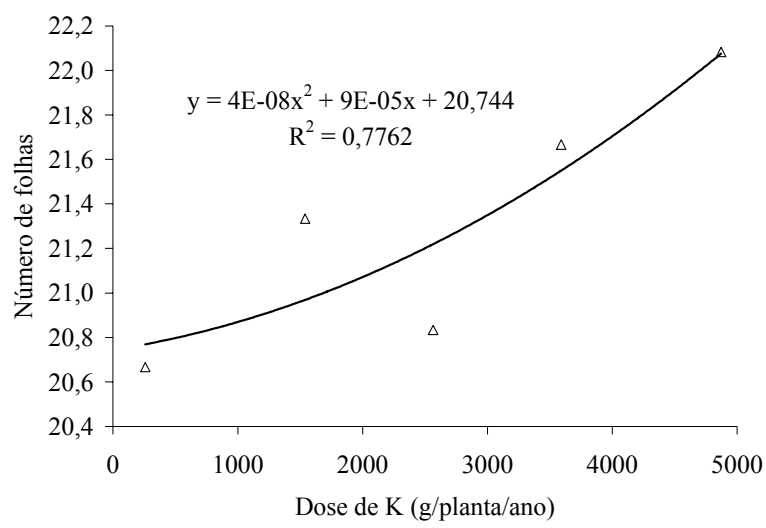

B

$Y=26,8183+0,000683^{N S N}-0,00000017^{\star} N^{2}+0,0001^{N S K}+0,00000006^{\star} N K$

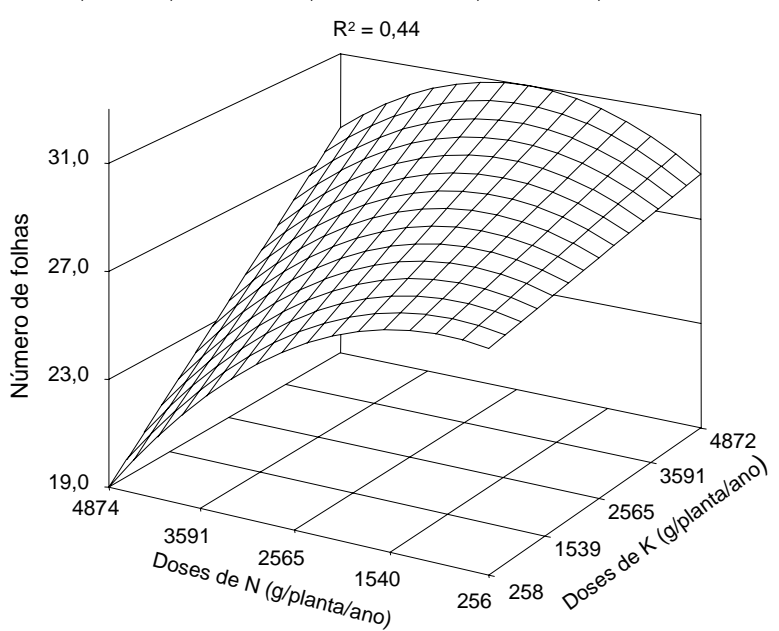

Figura 7 - Número de folhas vivas por planta durante o período chuvoso em função de doses de potássio (A) e superfície de resposta do período de estiagem (B) em função de doses de potássio e nitrogênio

Quando há um incremento nas doses de $\mathrm{N}$ juntamente com as doses de $\mathrm{K}$ percebe-se uma interação destes nutrientes, de forma a vir favorecer ao aumento do 
número de folhas vivas. Ainda com relação a essa época, a dose de $\mathrm{N}$ com maior representatividade no número de folhas vivas é $2565 \mathrm{~g} \mathrm{planta}^{-1}$ ano $^{-1}$. Portanto, o ambiente desempenhou um papel importante como um condicionador, no comportamento vegetativo, para o coqueiro. As análises deixam claro que a emissão foliar pode variar com a época do ano, como observado por Passos (1997).

O maior número de folhas vivas, como observado no presente trabalho, aumenta a área fotossintética, com probabilidade de uma maior quantidade de fotoassimilados para o crescimento e produção da planta a partir dos nutrientes absorvidos. Essas determinações inferem ao estádio da planta, que está diretamente relacionado ao tamanho da superfície foliar, pois quanto maior for a área foliar, maior será a superfície transpirante, e maior será o potencial para o uso de água (Pereira et al., 2002).

Apenas o fator número de folhas vivas não é suficiente para conhecer o potencial da planta para produzir fotoassimilados (Jucá et al., 2002). Ferreira Neto (2001), trabalhando sob as mesmas condições climáticas do trabalho em questão, para essa variedade de coqueiro em condições de salinidade, contabilizou uma emissão foliar de 16 folhas ano ${ }^{-1}$ com um número médio de 22,25 folhas planta $^{-1}$ no tratamento controle. Por outro lado Leite \& Encarnação (2002) relatam uma emissão média de folhas para a variedade anão verde de 11 folhas ano $^{-1}$ e que durante o período chuvoso a emissão teve maior freqüência.

Percebe-se que em condições de irrigação, o coqueiro anão tem seu desenvolvimento vegetativo favorecido na época de escassez de chuvas. Isto indica que na estação de escassez de chuvas houve melhor uso do $\mathrm{N}$ adicionado, com finalidade de estimular o crescimento vegetativo. Segundo Passos (1997), uma planta adulta de coqueiro anão sob condições ambientais favoráveis pode emitir 18 folhas no período de um ano. Os valores médios (22 folhas) observados para o número de folhas em todos os tratamentos durante o período chuvoso ficam abaixo da média de 25 a 30 folhas planta ${ }^{-1}$ mencionada por Child (1974). Segundo Passos (1997) quando o coqueiro é cultivado sob condições desfavoráveis, como com deficiência nutricional e condições ambientais desfavoráveis, ocorre redução no número de folhas vivas por planta, provavelmente devido à redução no ritmo de emissão foliar e à menor duração da folha. Esta duração 
provavelmente foi menor do que o mencionado por Child (1974), o qual relata que as folhas permanecem vivas por um período de 36 a 42 meses. Porém, Frémond et al. (1975) discordam da afirmação de que a redução do número de folhas na copa do coqueiro, sob condições ambientais desfavoráveis, é causada pela morte precoce da folha; segundo estes autores ela seria causada pela redução no ritmo de emissão foliar.

Ausência de resposta ao $\mathrm{K}$ no desenvolvimento da cultura foi observada por outros autores. De fato, o K não está associado ao aumento do vigor vegetativo das culturas, podendo atuar como "regulador" de crescimento, inibindo o crescimento excessivo quando a disponibilidade de $\mathrm{N}$ é alta.

$\mathrm{Na}$ avaliação de diâmetro de copa (Figura 8) encontrou-se efeitos significativos $(\mathrm{P} \leq 0,10)$ das doses de $\mathrm{N}$ e $\mathrm{K}$ isoladamente e quando interagiram entre si. As doses de $\mathrm{N}$ e K isoladamente têm pouca influencia no aumento do diâmetro.

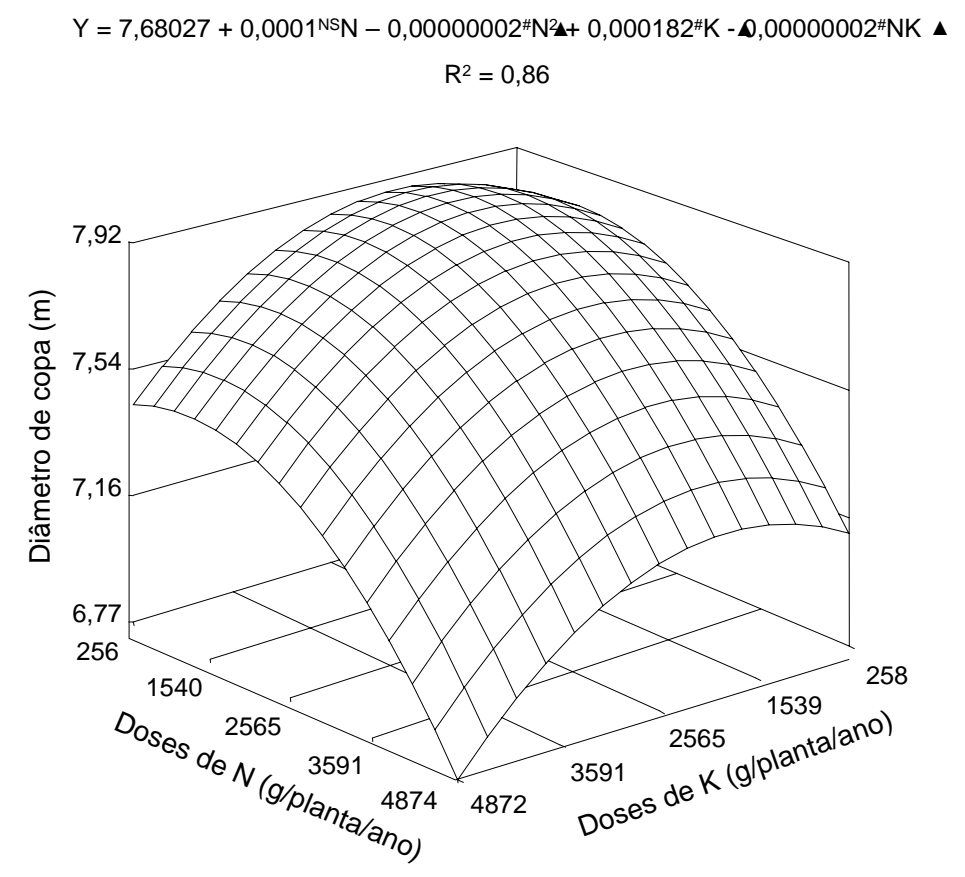

Figura 8 - Superfície de resposta relacionando diâmetro sombreado do coqueiro com doses de potássio e nitrogênio 
Quando esses fatores interagiram numa proporção de $1540 \mathrm{~g}$ de $\mathrm{N}$ com $2500 \mathrm{~g}$ de $\mathrm{K}$ induziram ao aumento do diâmetro de copa para aproximadamente $8 \mathrm{~m}$. A análise de correlação $\left(r^{2}=0,86\right)$ da supefície de resposta mostra que o diâmetro sombreado da área foliar foi menor com doses elevadas de $\mathrm{N}$ e K na fertirrigação.

Os resultados encontrados na determinação do diâmetro sombreado da copa do coqueiro traz a tona rever o espaçamento entre plantas para a variedade anão verde do Jiqui, que é recomendo o plantio em formação triangular de 7,5m. principalmente quando do uso das dosagens de fertirrigação ideais indicadas neste trabalho.

\subsection{Variáveis de produção}

\subsubsection{Florescimento}

A primeira inflorescência avaliada foi emitida, em média, 18 meses (julho de 2003) após o início das aplicações das doses de fertirrigação. A influência de algum fator na diferenciação das flores femininas ocorre de 11 a 12 meses antes da abertura da espata, por ser esse o tempo necessário para a diferenciação floral do coqueiro (Frémond et al., 1975).

O intervalo entre as emissões de inflorescências, durante o período analisado, não sofreu efeito significativo das doses de fertirrigação aplicadas. O coqueiro emitiu em 9 meses de observações, à contar de julho de 2003, um total de 12 inflorescências. Isto representa um intervalo médio entre emissões de 22 dias. Estes resultados divergem dos divulgados por Leite \& Encarnação (2002) onde relatam um intervalo médio de emissão para a variedade Anã de 28 dias. Estes autores afirmam ainda que durante os períodos secos houve picos de emissão de inflorescência, podendo ser atribuído ao fotoperíodo incidente. Aragão et al. (2002), apesar de não disponibilizar o intervalo, constatam que o cultivar Anão verde do Jiqui apresenta maior precocidade dentre todas as outras variedades e híbridos. Coomans (1975) atribui as variações de emissão de inflorescência, ao déficit hídrico ocorrido até dois anos antes da colheita, ou seja, um ano antes da 
abertura das flores. Acrescenta ainda, que variações sazonais do ritmo de emissão das inflorescências são influenciadas também pelo estado nutricional das plantas.

O número de flores femininas por inflorescência do coqueiro variou em função das condições nutricionais impostas pela fertirrigação do solo. Assim sendo, o número de flores femininas sofreu significativo $(\mathrm{P} \leq 0,01)$ efeito das doses de $\mathrm{N}$ e $\mathrm{K}$ sem que fossem verificadas interações entre elas. Observa-se pela superfície de resposta da Figura 9, que a medida em que se eleva a dose de $\mathrm{K}$ no solo, com redução em mesma ordem das doses de $\mathrm{N}$, o efeito é proporcional e evolutivo na quantidade de flores femininas por planta. As doses em torno de $2565 \mathrm{~g} \mathrm{planta}^{-1} \mathrm{ano}^{-1}$ de K e $1540 \mathrm{~g} \mathrm{planta}^{-1}$ ano $^{-1}$ de $\mathrm{N}$, apresentaram maiores médias na quantidade de flores femininas por planta durante o período. $\mathrm{O}$ aumento das doses de nitrogênio no solo acima da dose mencionada anteriormente (1540 $\left.\mathrm{g} \mathrm{planta}^{-1} \mathrm{ano}^{-1}\right)$ provoca uma redução brusca para esta variável.

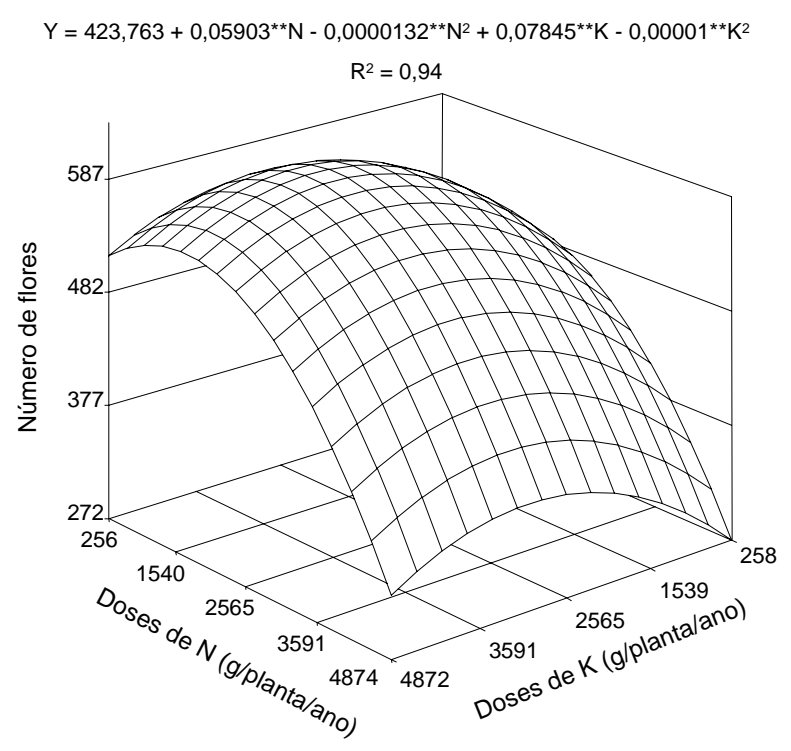

Figura 9 - Superfície de resposta do número total de flores do coqueiro em função de doses de potássio e nitrogênio

$\mathrm{O}$ coqueiro, nesse caso, revela uma alta eficiência no uso do $\mathrm{N}$ aplicado e que o aumento excessivo nas dosagens de $\mathrm{N}$ proporcionam redução na média satisfatória do 
número de flores femininas por inflorescência. Este fato é comprovado pela maior curvatura e decréscimo da linha do fator "doses de N".

O potássio é mais reivindicado pela planta no aumento do número de flores femininas do coqueiro. Destacando-se a importância do nutriente na produtividade da planta. $\mathrm{O}$ total de flores femininas por inflorescência em coqueiro da variedade Gigante varia de 20 a 40, com tendência de aumento no coqueiro da variedade Anão (FAO, 1984). Este fato foi comprovado por Ferreira Neto (2001) em condições de salinidade, chegando a produzir aproximadamente 240 flores femininas por inflorescência, muito embora, este valor não se reflita no maior número de frutos (Marinho, 2002).

É mais comum cada inflorescência apresentar de 40 a 60 flores femininas, sendo que, o número de flores femininas é muito mais instável do que o número de flores masculinas (Miranda Júnior, 1948). Frémond et al. (1966) defendem que o pequeno número de flores pode estar relacionado às condições desfavoráveis de umidade, durante os meses em que ocorre a diferenciação. Para isso, o coqueiro requer condições edafoclimáticas satisfatórias para manter sua carga produtiva, uma vez que a planta emite inflorescências continuamente durante todo o ano, sendo portanto encontrados frutos nos diferentes estádios de desenvolvimento.

\subsubsection{Produção de frutos}

As produções do coqueiro no $6^{\circ}$ e $7^{\circ}$ ano de cultivo, sob influência das doses de $\mathrm{N}$ e K, apresentaram médias satisfatórias com relação ao número de frutos colhidos por planta por ano. Isso porque, a média geral entre todos os tratamentos ficou acima de 200 frutos planta $^{-1}$ ano $^{-1}$. Para uma produção comercial de coco verde sob condição de irrigação esta produção é bastante satisfatória, lembrando-se de referenciar à idade de cultivo. O número de frutos foi influenciado significativamente pelas doses de $\mathrm{N}$ apresentando efeito quadrático $(\mathrm{P} \leq 0,01)$ nos dois anos $\left(6^{\circ}\right.$ e $\left.7^{\circ}\right)$ de produção. Já o efeito $(\mathrm{P} \leq 0,05)$ do $\mathrm{K}$ se mostrou influente na quantidade de frutos planta ${ }^{-1}$ apenas no $6^{\circ}$ ano. Para os anos de produção em análise não houve interação entre as doses de $\mathrm{N}$ e K. 
Pode-se observar pela superfície de resposta apresentada na Figura 10, que na medida em que se eleva a dose de $\mathrm{K}$ e $\mathrm{N}$ no solo, o efeito é revertido numa maior quantidade de frutos por planta. A dose de $2910 \mathrm{~g} \mathrm{planta}^{-1}$ ano $^{-1}$ de $\mathrm{K}_{2} \mathrm{O}$ e $2353 \mathrm{~g} \mathrm{planta}^{-1}$ ano $^{-1}$ de $\mathrm{N}$, representam os níveis para obtenção da quantidade máxima de frutos por planta para o $6^{\circ}$ ano de cultivo. O aumento das doses de nitrogênio e potássio no solo, acima destas mencionadas, chega a provocar redução na produção de frutos por planta. A dose econômica na fertirrigação para o $6^{\circ}$ ano de produção correspondeu a $2243 \mathrm{~g}$ de $\mathrm{N}$ planta ${ }^{-1}$ ano $^{-1}$ e $2786 \mathrm{~g}$ de $\mathrm{K}_{2} \mathrm{O}$ planta $^{-1} \mathrm{ano}^{-1}$, considerando os preços vigentes na região: $\mathrm{R} \$ 0,27$ por coco verde; $\mathrm{R} \$ 1,67 \mathrm{~kg}^{-1}$ de $\mathrm{N}$ e $\mathrm{R} \$ 1,45 \mathrm{~kg}^{-1}$ de $\mathrm{K}_{2} \mathrm{O}$.

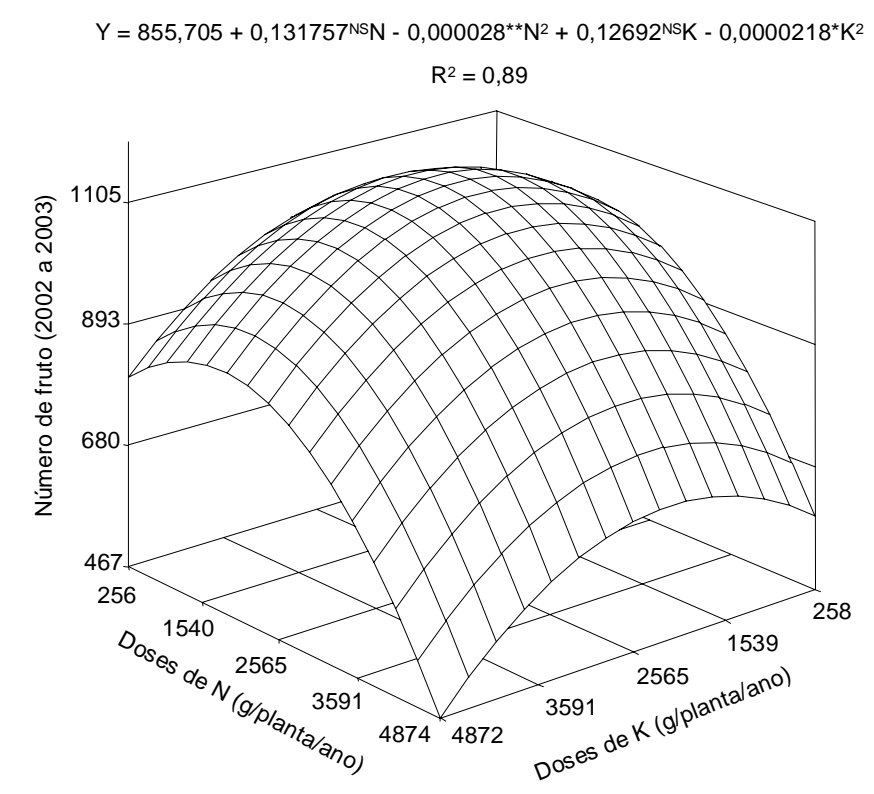

Figura 10 - Superfície de resposta do número total de frutos colhidos no $6^{\circ}$ ano de cultivo, em função de doses de potássio e nitrogênio aplicadas via fertirrigação

No $7^{\circ}$ ano (Figura 11) a dose de $\mathrm{N}$ com maior expressividade na produção média

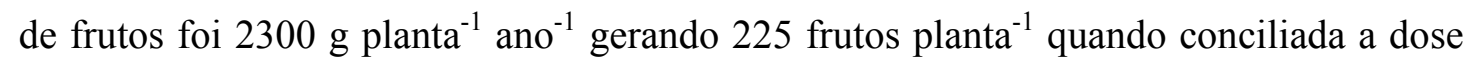
similar para o potássio. Porém esse aumento se deu de forma suave. A dose econômica de fertirrigação para o $7^{\circ}$ ano de produção correspondeu também a $1540 \mathrm{~kg}$ de N planta ${ }^{-1}$ 
e $1539 \mathrm{~kg}$ de $\mathrm{K}_{\text {planta }}{ }^{-1}$. Mesmo ao se considerar que não houve efeito significativo do $\mathrm{K}$ no aumento de produção deste ano.

O aumento das doses a partir daquelas de maior expressão na produção proporcionaram um consumo de luxo já que não se reflete em aumento da produção. Pelas observações realizadas neste ano, a redução na quantidade exigida de $\mathrm{N}$ pela planta, na comparação entre as maiores produções, pode ser explicada pela manutenção da concentração desse nutriente ao longo do período de estudo e também pela tendência de estabilização da produção que é alcançada pela planta a partir do $7^{\circ}$ ano de cultivo. Estes incrementos de produção gerados pela adição de $\mathrm{N}$ divergem de pesquisas já realizadas (Lins, 2000; IRHO, 1989; Ollagnier \& Wahyuni, 1984; Manciot et al., 1980)

Segundo Lins (2000), trabalhando com coqueiro híbrido, em dez anos de produção, a aplicação de nitrogênio na forma de uréia não influenciou nas variáveis de produção mensuradas como cocos planta $^{-1}$ e peso de albúmem fruto ${ }^{-1}$. Outros autores (Ollagnier \& Wahyuni, 1984) convergem para esta mesma afirmação, sob a aplicação de nitrogênio na forma de uréia não ter proporcionado efeito significativo em termos de coco planta $^{-1}$. Mas ressaltam que o único efeito observado ocorreu em experimentos onde o solo era extremamente saturado e sem cobertura verde. Para o trabalho em estudo, o ambiente condiz parcialmente com o descrito pelos autores anteriormente citados, de forma que a alta frequência de irrigação localizada, as capinas freqüentes e o pastejo dos ovinos na área experimental remontam à essa mesma condição. Outros fatores que se devem levar em consideração é o solo arenoso, o parcelamento das doses de $\mathrm{N}$ e a sua forma de aplicação. Essas características de cultivo induzem ao consumo do $\mathrm{N}$ adicionado na forma de uréia à planta.

Segundo IRHO (1989), em plantações de coco bem administradas com leguminosa na cobertura do solo, implantada desde o início do cultivo, a leguminosa satisfaz a nutrição de nitrogênio, apesar do baixo teor de matéria orgânica e de $\mathrm{N}$ nos solos. Isto porque os autores em 10 anos de pesquisa, utilizando a variedade gigante e um híbrido de coco, não confirmaram a influência da adubação nitrogenada no aumento da produção de coco planta $^{-1}$, nem na quantidade de albúmem sólido produzido. Lins (2000) comprovou essa afirmação observando que apenas a cobertura do solo com 
leguminosa, garante tanto a proteção do solo quanto o suprimento de nitrogênio as plantas.

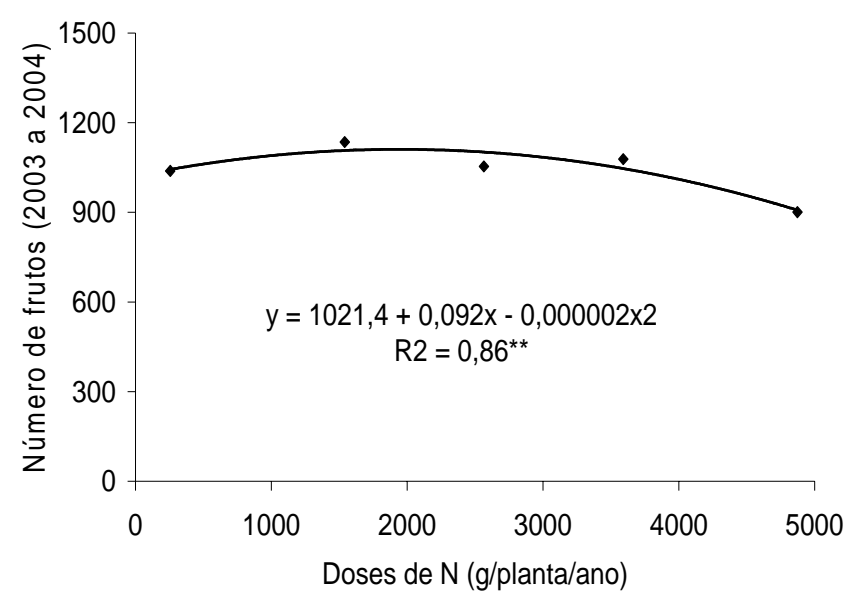

Figura 11 - Número total de frutos colhidos no $7^{\circ}$ ano de cultivo, em função das doses de nitrogênio aplicadas via fertirrigação

Bezerra (2002), ao conduzir experimentos com irrigação aplicada ao coqueiro anão em condições ambientais semelhantes aos deste trabalho, menciona produções médias de até 270 frutos planta ${ }^{-1}$ já a partir do terceiro ano de produção (corresponde em média ao $6^{\circ}$ ano de cultivo), sem haver diferenças entre os tratamentos de volume de água aplicada; havendo diferença apenas entre os anos de produção. Este autor utilizou $2000 \mathrm{~g}_{\text {planta }}{ }^{-1}$ ano $^{-1}$ de N e 3300 g planta $^{-1}$ ano $^{-1}$ de $\mathrm{K}$ para o ano de maior produção. Essa dosagem se situa dentro da faixa ótima para maior produção do presente trabalho. Rosa Júnior (2000) também relata expressiva produção do coqueiro anão (300 frutos planta $^{-1}$ ano $^{-1}$ ) nas condições da região do Submédio São Francisco.

Diante de todos os relatos, inclusive de agricultores, não se percebe a estabilização de produtividade em relação aos picos de produção ocorridos durante os vários anos consecutivos. Este comportamento é explicado principalmente pela exaustão fisiológica da planta em decorrência da extração precoce dos frutos, ainda verdes, em grande quantidade. $\mathrm{O}$ coqueiro anão com finalidade de produção de água de coco, não consegue completar o ciclo natural da vida, ou seja, seus frutos são retirados antes que 
eles atinjam a maturação. Nessa condição tendem a produzir mais frutos. A produção de coco verde foi determinada pelo mercado e não por uma condição natural da planta.

Quando Lins (2000) avaliou a adubação potássica sob o coqueiro híbrido observou que esse nutriente teve efeito negativo na produção de coco planta $^{-1}$ no segundo, terceiro e quinto ano de colheita chegando a uma redução de $11,3 \%$. O autor relata que o $\mathrm{KCl}$ só se tornou influente no número de coco planta ${ }^{-1}$ a partir do sexto ano.

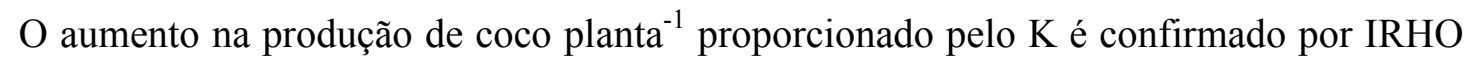
(1989) chegando a aumentar em mais de $100 \%$ quando o coqueiro gigante foi cultivado em areia litorânea. Percebe-se que a eficiência e o efeito do nutriente torna-se mais pronunciado quando a planta está submetida a uma condição de deficiência nutricional. Muito embora esse efeito benéfico da adubação só venha a se refletir num prazo médio de dois anos.

\subsection{Qualidade da Produção}

A análise de variância (Tabela 7) não indicou efeito dos fatores experimentais sobre o peso de fruto, havendo efeito significativo das doses de $\mathrm{N}$ para volume (Vol.), $\mathrm{pH}$ e ${ }^{\circ}$ Brix da água de coco. As doses de $\mathrm{K}$ tiveram efeito significativo sobre a condutividade elétrica da água de coco (CEac) e o ${ }^{\circ}$ Brix da água de coco.

$\mathrm{O}$ incremento de $\mathrm{N}$ na fertirrigação mostra uma tendência significativa $(\mathrm{P} \leq 0,01)$ na redução do volume da água de coco, como é visto na Figura $12 \mathrm{~A}$. O volume da água de coco geralmente apresenta tendência semelhante ao peso do fruto. Porém, frutos de maior peso não repercutiram em volumes maiores de água de coco. Portanto os frutos foram favorecidos discretamente pelas doses de $\mathrm{N}$ no maior desenvolvimento do mesocarpo em detrimento da menor cavidade interna de frutos. Observa-se que o volume médio de água de coco ficou acima de $450 \mathrm{~mL}$ (Figura $12 \mathrm{~A}$ ) chegando a valores máximos de $500 \mathrm{~mL}$ em relação as doses de N. Esses resultados são superiores aos valores médios de 384,26 mL relatados em Camboim Neto (2002); aos obtidos por EMPARN (2001) com 258,00 mL em frutos com seis meses de idade, e também aos obtidos por Aragão et al. (2001) que apresentam volumes médios de 394,65 mL. 
Tabela 7. Resumo da análise de variância dos componentes de qualidade dos frutos de coco verde sobre os valores médios de peso, volume, $\mathrm{pH}$, condutividade elétrica (CEac) e ${ }^{\circ}$ Brix da água de coco.

\begin{tabular}{|c|c|c|c|c|c|}
\hline \multirow{2}{*}{ Fonte de variação } & \multicolumn{5}{|c|}{ Valores de F } \\
\hline & Peso & Vol. & $\mathrm{pH}$ & CEac & ${ }^{\circ}$ Brix \\
\hline Efeito linear do $\mathrm{N}$ & $\mathrm{ns}$ & $20,94 * *$ & $8,23 * *$ & ns & $37,58 * *$ \\
\hline Efeito quadrático do $\mathrm{N}$ & ns & ns & ns & ns & Ns \\
\hline Efeito linear do $\mathrm{K}$ & $\mathrm{ns}$ & $\mathrm{ns}$ & ns & $2,71^{\wedge}$ & $145,27 * *$ \\
\hline Efeito quadrático do $\mathrm{K}$ & $\mathrm{ns}$ & $\mathrm{ns}$ & $\mathrm{ns}$ & $14,97 * *$ & $24,58 * *$ \\
\hline Efeito linear $\mathrm{N}^{*} \mathrm{~K}$ & ns & $\mathrm{ns}$ & ns & ns & $\mathrm{ns}$ \\
\hline C.V $(\%)$ & 3,00 & 4,01 & 1,75 & 0,72 & 2,11 \\
\hline
\end{tabular}

$\mathrm{O}$ pH da água de coco sofreu efeito significativo das doses de nitrogênio aplicadas na fertirrigação, não sendo caracterizada a influência do potássio para essa variável. $\mathrm{O}$ pH da água de coco (Figura $12 \mathrm{~B}$ ) teve seu valor alterado entre 5,6 e 5,8, em relação às doses de nitrogênio, na medida em que estas eram incrementadas na fertirrigação. Para muitos autores a faixa de $\mathrm{pH}$ da água de coco situa-se entre 4,5 a 5,7. Trabalho conduzido pela EMPARN (2001) observou que o pH varia de 4,6 a 5,8 nos diferentes estádios de maturação (do $5^{\circ}$ ao $9^{\circ}$ mês), atingindo o valor máximo no $7^{\circ}$ mês. Rosa \& Abreu (2000) encontraram pH igual a 4,9 em frutos com sete meses de idade. Segundo Kumar et al. (1975) o pH da água de coco varia de 4,8 a 5,2 em frutos com idade entre 6 e 12 meses. Tavares et al. (1998) estudaram a composição química da água de coco anão verde em diferentes estádios de maturação e constataram que o sabor doce e a adstringência desejável da água de coco são atingidos com $\mathrm{pH}$ próximo a 5,6 em frutos com 8 a 12 meses de idade. $\mathrm{O}$ pH baixo poderá ter maior importância quando o fruto se destina ao processo industrial, como no caso de engarrafamento, face à inibição do crescimento bacteriano em soluções ácidas.

A condutividade elétrica da água de coco não sofreu efeito pela adição de nitrogênio e decresceu significativamente $(\mathrm{P} \leq 0,01)$ com o incremento da dose de potássio na fertirrigação (Figura $12 \mathrm{C}$ ). 
(A)

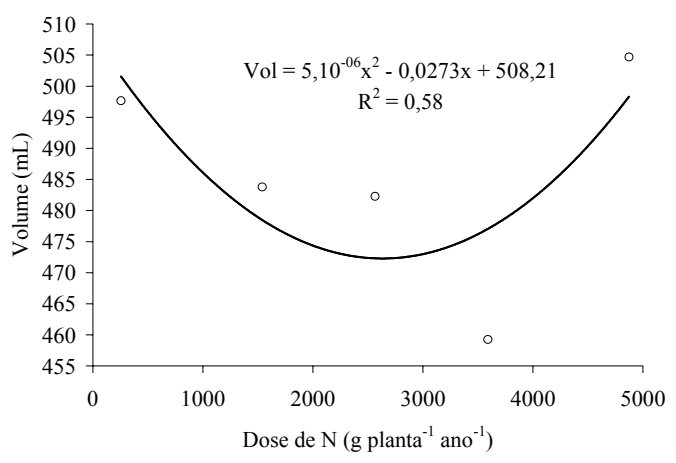

(B)

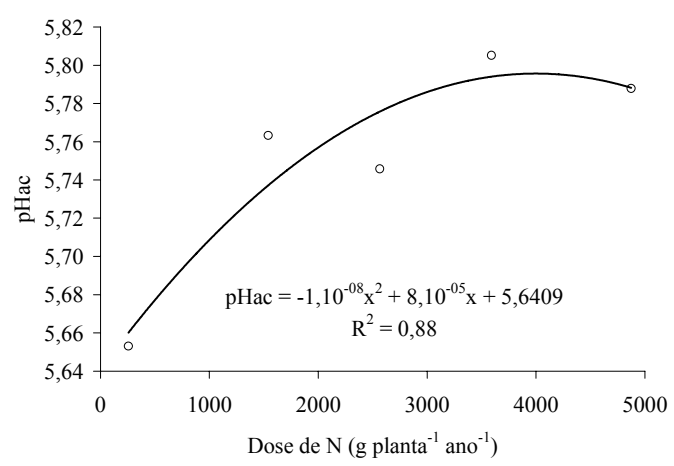

(C)

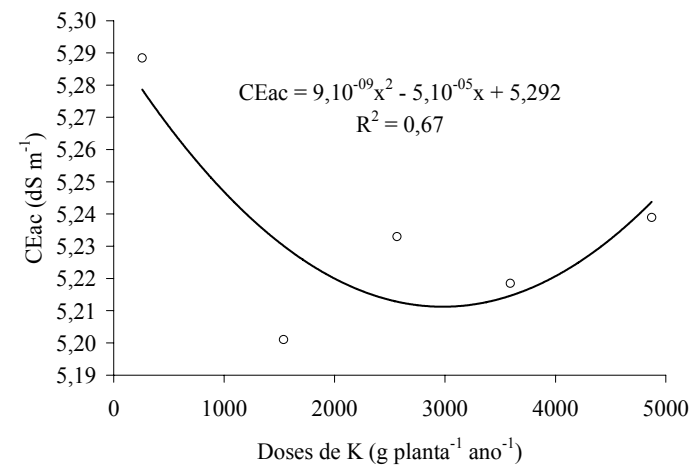

Figura 12 - Caracterização dos valores médios de volume (A), pH (B) e CEac da água de coco $(\mathrm{C})$ em função de doses de potássio e nitrogênio aplicadas via fertirrigação

Maiores doses de potássio na fertirrigação do coqueiro, a partir de $258 \mathrm{~g} \mathrm{planta}^{-1}$ ano $^{-1}$, repercutiram em menores valores de CE da água de coco com valores médios em torno de 5,23 $\mathrm{dS} \mathrm{m}^{-1}$ (Figura 12, C). Estes valores medidos diferem dos divulgados $(3,58$ 
$\mathrm{dS} \mathrm{m}^{-1}$ ) pela EMPARN (2001) em frutos da mesma idade. Camboim Neto (2002), trabalhando com lâminas de irrigação no coqueiro, revela uma CE média de $5,57 \mathrm{dS} \mathrm{m}^{-1}$ em água de frutos com 7 meses e que o incremento na lâmina d'água de irrigação reduz o valor dessa variável na água de coco, embora se tratando de uma diferença de 0,03 dS $\mathrm{m}^{-1}$. Efeito positivo ao incremento da CE da água de coco foi constatado por Ferreira Neto et al., (2002) e Marinho (2002), quando o coqueiro foi submetido à salinidade da água de irrigação.

$\mathrm{O}{ }^{\circ}$ Brix representa a percentagem de sólidos solúveis totais incluindo os ácidos e os açucares. A análise dos resultados de sólidos solúveis tem seu esboço na superfície de resposta presente na Figura 13, onde pode se observar que na medida em que se aumentou a quantidade de $\mathrm{K}$, fornecida pelo $\mathrm{KCl}$ via fertirrigação, promoveu também a elevação no valor do ${ }^{\circ}$ Brix da água de coco. Os maiores valores de ${ }^{\circ}$ Brix foram observados com a aplicação da maior dose de $\mathrm{K}$ (4872 $\mathrm{g}_{\text {planta }}{ }^{-1}$ ano $\left.^{-1}\right)$. O incremento na dose de nitrogênio na fertirrigação diminui o valor do ${ }^{\circ}$ Brix encontrado na água de coco. $\mathrm{Na}$ análise da interação entre os fatores doses de $\mathrm{N}$ e de $\mathrm{K}$ não foi identificado efeito significativo.

Apesar das pequenas diferenças numéricas entre os valores de ${ }^{\circ}$ Brix, em termos percentuais, existe uma amplitude de $20 \%$ entre a maior e a menor leitura. Acredita-se que valores de ${ }^{\circ}$ Brix para água de coco acima de seis $\left(6,0^{\circ}\right)$ proporcionam a este produto um sabor agradável e de grande aceitação pelo mercado consumidor local (Natal-RN). Neste caso (frutos colhidos aos sete meses), quanto maior o teor de açúcar melhor o sabor da água de coco. Essa resposta é uma característica de alto valor produtivo e comercial, pois a aceitação por água de coco mais doce torna-se o diferencial nesse produto. Essa é também uma vantagem para indústria de envasamento de água de coco, que na maioria das vezes adiciona adoçantes, como a frutose, para agregar qualidade à bebida e proporcionar uma maior palatabilidade ao produto. As maiores indústrias deste seguimento fazem a mistura de águas de coco seco e verde dando vazão ao vultuoso subproduto (água de coco) gerado a partir do beneficiamento do coco seco que é a prioridade da indústria de coco no Brasil. Com isso eleva o teor de gordura e também a quantidade de sólidos solúveis na bebida sendo constatado pelo aumento do ${ }^{\circ}$ Brix. 


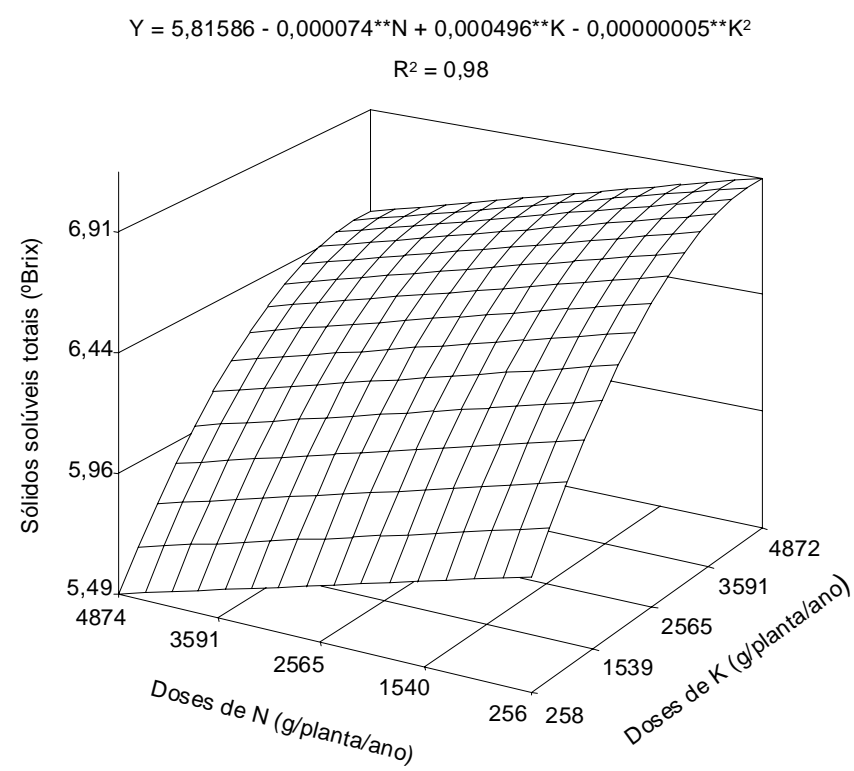

Figura 13 - Superfície de resposta relacionando o ${ }^{\circ}$ Brix da água de coco, com doses de potássio e nitrogênio aplicadas via fertirrigação

Há uma tendência de aumento do ${ }^{\circ}$ Brix e redução da $\mathrm{CE}$, o que se deve ao incremento do teor de $\mathrm{K}$ na água de coco proporcionado pelas dosagens de fertirrigação. Portanto, pode se utilizar a leitura da CE numa aproximação prática da estimativa do ${ }^{\circ}$ Brix da água de coco. O que se pretende com esse comentário é mostrar a importância e tornar mais usual a leitura de CE na água de coco para denotar padrões de qualidade a esse produto. Observou-se também, menor resistência ao corte dos frutos tratados com maiores dosagens de nitrogênio e potássio. Este fato pode está associado ao metabolismo dos carboidratos da parede celular, que resultam na redução de sua firmeza. Este comportamento foi verificado em outros cultivos quando submetidos a doses crescentes de nitrogênio e potássio na fertirrigação (Nannetti, 2001; Sakurai \& Neves,1993).

\subsection{Fertilidade do solo}

\subsubsection{Profundidade e época de amostragem}

A amostragem realizada foi feita de modo adequado e representativo a esta situação. A análise para diferentes profundidades de amostragem do solo vista na Tabela 
8, possibilita uma comparação (Tukei a 5\%) entre os resultados. Estes revelam que as concentrações de $\mathrm{Ca}, \mathrm{Mg}, \mathrm{P}$ e $\mathrm{K}$ foram maiores na camada de $0-5 \mathrm{~cm}$ e menores na de 20-40 cm do perfil do solo; nas três avaliações (dezembro de 2002, junho de 2003 e dezembro de 2003) em relação aos tratamentos empregados nas dosagens de fertirrigação. As concentrações dos nutrientes variaram bastante, tanto nos intervalos de amostragem quanto nas camadas. Provavelmente este fato esteja relacionado à ocorrência de pontos de alta concentração desses nutrientes, principalmente nas camadas superficiais. Por outro lado, a fertilização semestral química e orgânica de cobertura favoreceu o fornecimento dos nutrientes adequados às exigências da cultura. Pode ser visto pela Figura 14 a distribuição do K no solo com o incremento de $\mathrm{K}$ nas doses de fertirrigação.

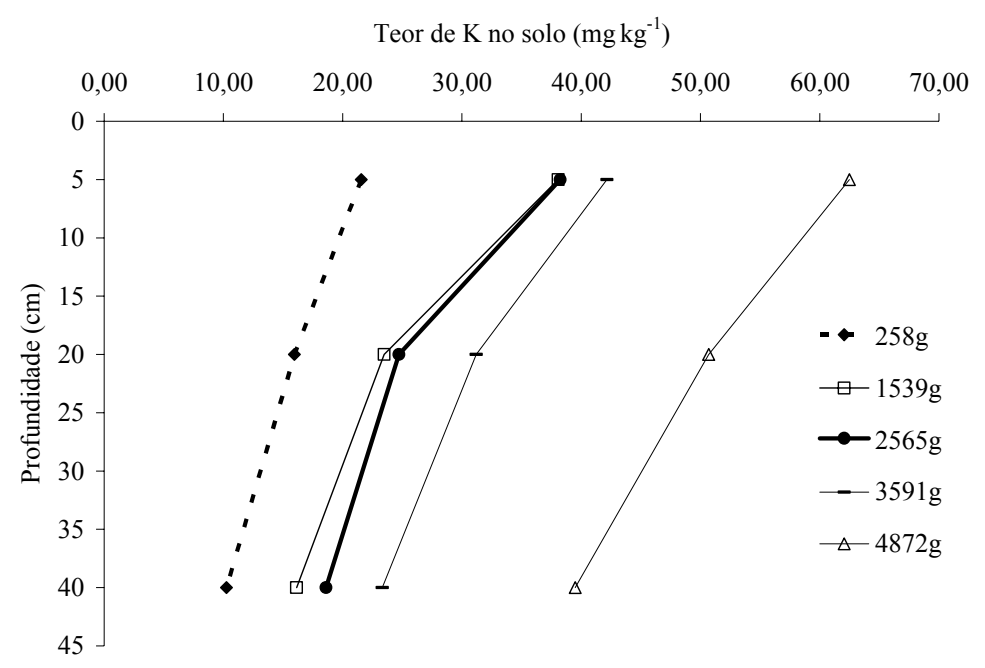

Figura 14 - Teor médio de K no perfil do solo de acordo com as doses de K aplicadas 
Tabela 8. Médias* dos teores de $\mathrm{Ca}, \mathrm{Mg}, \mathrm{P}$ e $\mathrm{K}$ nas profundidades de 0-5 $\mathrm{cm}, 0-20 \mathrm{~cm}$ e de $20-40 \mathrm{~cm}$ para os diferentes tratamentos nos períodos de fevereiro e junho de 2003, e em fevereiro de 2004

\begin{tabular}{|c|c|c|c|c|c|c|c|c|c|c|c|c|c|}
\hline \multirow{2}{*}{ Mês } & & & \multirow{2}{*}{ Prof. } & \multicolumn{10}{|c|}{ Tratamento } \\
\hline & \multirow{7}{*}{ 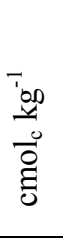 } & & & 1 & 2 & 3 & 4 & 5 & 6 & 7 & 8 & 9 & 10 \\
\hline \multirow{12}{*}{ 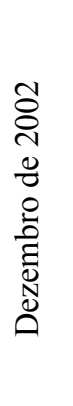 } & & \multirow{4}{*}{$\mathrm{Ca}$} & $0-5$ & $0,69 \mathrm{a}$ & $0,75 \mathrm{a}$ & $0,45 \mathrm{a}$ & $0,15 \mathrm{a}$ & $2,24 \mathrm{a}$ & $0,64 \mathrm{a}$ & $0,43 \mathrm{a}$ & $0,85 \mathrm{a}$ & $1,16 \mathrm{a}$ & $0,97 \mathrm{a}$ \\
\hline & & & $0-20$ & $0,49 \mathrm{a}$ & $0,62 \mathrm{a}$ & $0,32 \mathrm{a}$ & $0,47 \mathrm{a}$ & $1,12 \mathrm{~b}$ & $0,25 \mathrm{a}$ & $0,24 \mathrm{a}$ & $0,63 \mathrm{a}$ & $0,23 \mathrm{~b}$ & $0,36 \mathrm{ab}$ \\
\hline & & & $20-40$ & $0,20 \mathrm{a}$ & $0,24 \mathrm{a}$ & $0,32 \mathrm{a}$ & $0,17 \mathrm{a}$ & $0,30 \mathrm{c}$ & $0,13 \mathrm{a}$ & $0,13 \mathrm{a}$ & $0,27 \mathrm{a}$ & $0,19 \mathrm{~b}$ & $0,12 \mathrm{~b}$ \\
\hline & & & $0-5$ & $0,14 \mathrm{a}$ & $0,14 \mathrm{a}$ & 0,08 a & $0,05 \mathrm{a}$ & $0,42 \mathrm{a}$ & $0,11 \mathrm{a}$ & $0,12 \mathrm{a}$ & $0,10 \mathrm{a}$ & $0,24 \mathrm{a}$ & $0,27 \mathrm{a}$ \\
\hline & & \multirow[t]{2}{*}{$\mathrm{Mg}$} & $0-20$ & $0,12 \mathrm{a}$ & $0,11 \mathrm{a}$ & $0,06 \mathrm{a}$ & 0,08 a & $0,22 \mathrm{~b}$ & $0,07 \mathrm{a}$ & $0,07 \mathrm{a}$ & $0,08 \mathrm{a}$ & $0,06 \mathrm{~b}$ & $0,10 \mathrm{~b}$ \\
\hline & & & $20-40$ & $0,05 \mathrm{a}$ & $0,05 \mathrm{a}$ & $0,05 \mathrm{a}$ & 0,04 a & $0,10 \mathrm{c}$ & $0,04 \mathrm{a}$ & $0,04 \mathrm{a}$ & 0,05 a & $0,04 \mathrm{~b}$ & $0,03 \mathrm{~b}$ \\
\hline & \multirow{7}{*}{ 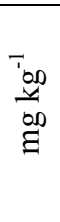 } & \multirow{4}{*}{$\mathrm{P}$} & $0-5$ & $29,38 \mathrm{a}$ & $44,38 \mathrm{a}$ & $65,00 \mathrm{a}$ & $48,75 \mathrm{a}$ & 58,25 a & $74,38 \mathrm{a}$ & $43,13 \mathrm{a}$ & 82,63 a & $48,13 \mathrm{a}$ & $30,00 \mathrm{a}$ \\
\hline & & & $0-20$ & $21,75 \mathrm{ab}$ & $10,88 \mathrm{~b}$ & $35,00 \mathrm{~b}$ & $29,63 \mathrm{a}$ & $20,00 \mathrm{~b}$ & $31,25 \mathrm{~b}$ & $32,50 \mathrm{ab}$ & $52,50 \mathrm{~b}$ & $28,33 \mathrm{a}$ & $7,50 \mathrm{~b}$ \\
\hline & & & $20-40$ & $7,50 \mathrm{~b}$ & $6,88 \mathrm{~b}$ & $8,00 \mathrm{c}$ & $6,25 \mathrm{~b}$ & $11,38 \mathrm{~b}$ & $15,63 \mathrm{~b}$ & $13,88 \mathrm{~b}$ & $27,50 \mathrm{c}$ & $6,38 \mathrm{~b}$ & $5,00 \mathrm{~b}$ \\
\hline & & & $0-5$ & $40,09 \mathrm{a}$ & $86,32 \mathrm{a}$ & $39,15 \mathrm{a}$ & $71,93 \mathrm{a}$ & $76,42 \mathrm{a}$ & $135,89 \mathrm{a}$ & $16,04 \mathrm{a}$ & $47,17 \mathrm{a}$ & $47,88 \mathrm{a}$ & $32,78 \mathrm{a}$ \\
\hline & & \multirow[t]{3}{*}{ K } & $0-20$ & $35,14 \mathrm{a}$ & $68,40 \mathrm{ab}$ & $36,32 \mathrm{a}$ & $67,22 \mathrm{a}$ & $38,44 \mathrm{~b}$ & $145,07 \mathrm{a}$ & $15,60 \mathrm{a}$ & $40,16 \mathrm{a}$ & $40,57 \mathrm{ab}$ & $20,75 \mathrm{a}$ \\
\hline & & & $20-40$ & $23,35 \mathrm{a}$ & $55,66 \mathrm{~b}$ & $38,92 \mathrm{a}$ & $55,19 \mathrm{a}$ & $24,65 \mathrm{~b}$ & $129,43 \mathrm{a}$ & $7,66 \mathrm{a}$ & $33,25 \mathrm{a}$ & $22,98 \mathrm{~b}$ & $15,56 \mathrm{a}$ \\
\hline \multirow{12}{*}{ 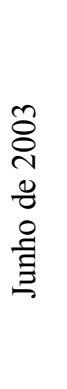 } & & & $0-5$ & $1,02 \mathrm{a}$ & $1,02 \mathrm{a}$ & $0,71 \mathrm{a}$ & $0,77 \mathrm{a}$ & $2,09 \mathrm{a}$ & $0,38 \mathrm{a}$ & $0,74 \mathrm{a}$ & $0,72 \mathrm{a}$ & $0,73 \mathrm{a}$ & $3,11 \mathrm{a}$ \\
\hline & \multirow{5}{*}{ 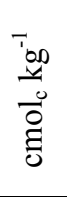 } & \multirow[t]{2}{*}{$\mathrm{Ca}$} & $0-20$ & $0,24 \mathrm{~b}$ & $0,41 \mathrm{~b}$ & $0,33 \mathrm{ab}$ & $0,43 \mathrm{ab}$ & $1,41 \mathrm{~b}$ & $0,21 \mathrm{a}$ & $0,58 \mathrm{ab}$ & $0,30 \mathrm{a}$ & $1,24 \mathrm{~b}$ & $1,03 \mathrm{~b}$ \\
\hline & & & $20-40$ & $0,31 \mathrm{~b}$ & $0,26 \mathrm{~b}$ & $0,04 \mathrm{~b}$ & $0,08 \mathrm{~b}$ & $0,45 \mathrm{c}$ & $0,11 \mathrm{a}$ & $0,21 \mathrm{~b}$ & $0,24 a$ & $0,38 \mathrm{~b}$ & $0,38 \mathrm{c}$ \\
\hline & & \multirow{4}{*}{$\mathrm{Mg}$} & $0-5$ & $0,31 \mathrm{a}$ & $0,22 \mathrm{a}$ & $0,18 \mathrm{a}$ & $0,31 \mathrm{a}$ & $0,56 \mathrm{a}$ & $0,10 \mathrm{a}$ & $0,25 \mathrm{a}$ & $0,26 a$ & $0,22 \mathrm{a}$ & $0,69 \mathrm{a}$ \\
\hline & & & $0-20$ & $0,14 \mathrm{ab}$ & $0,06 \mathrm{a}$ & $0,11 \mathrm{a}$ & $0,13 \mathrm{ab}$ & $0,43 \mathrm{a}$ & $0,03 \mathrm{a}$ & $0,14 \mathrm{ab}$ & $0,05 \mathrm{~b}$ & $0,64 \mathrm{~b}$ & $0,19 \mathrm{~b}$ \\
\hline & & & $20-40$ & $0,04 \mathrm{~b}$ & $0,03 \mathrm{a}$ & $0,05 \mathrm{a}$ & $0,07 \mathrm{~b}$ & $0,11 \mathrm{~b}$ & $0,03 \mathrm{a}$ & $0,04 \mathrm{~b}$ & $0,02 \mathrm{~b}$ & $0,19 \mathrm{~b}$ & $0,12 \mathrm{~b}$ \\
\hline & \multirow{6}{*}{ 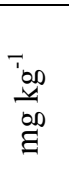 } & & $0-5$ & 66,00 a & $75,25 \mathrm{a}$ & $71,50 \mathrm{a}$ & $45,33 \mathrm{a}$ & $40,83 \mathrm{a}$ & $69,00 \mathrm{a}$ & $63,33 \mathrm{a}$ & $96,00 \mathrm{a}$ & 86,00 a & $113,25 \mathrm{a}$ \\
\hline & & \multirow[t]{3}{*}{$\mathrm{P}$} & $0-20$ & $45,50 \mathrm{ab}$ & $35,25 \mathrm{~b}$ & $71,00 \mathrm{a}$ & $28,75 \mathrm{ab}$ & $63,75 \mathrm{ab}$ & $49,92 \mathrm{a}$ & $65,00 \mathrm{a}$ & $40,00 \mathrm{~b}$ & $99,33 \mathrm{a}$ & $30,00 \mathrm{~b}$ \\
\hline & & & $20-40$ & $26,00 \mathrm{~b}$ & $6,00 \mathrm{~b}$ & $28,00 \mathrm{~b}$ & $10,33 \mathrm{~b}$ & $22,00 \mathrm{~b}$ & $23,08 \mathrm{a}$ & $16,75 \mathrm{~b}$ & $7,00 \mathrm{c}$ & $31,50 \mathrm{~b}$ & $16,00 \mathrm{~b}$ \\
\hline & & & $0-5$ & $23,75 \mathrm{a}$ & $45,75 \mathrm{a}$ & $40,00 \mathrm{a}$ & 39,83 a & $31,00 \mathrm{a}$ & $39,25 \mathrm{a}$ & $15,00 \mathrm{a}$ & $37,25 \mathrm{a}$ & $35,25 \mathrm{a}$ & $25,50 \mathrm{a}$ \\
\hline & & \multirow{3}{*}{$\mathrm{K}$} & $0-20$ & $14,75 \mathrm{a}$ & $28,75 \mathrm{~b}$ & $20,25 \mathrm{~b}$ & $24,67 \mathrm{~b}$ & $28,50 \mathrm{a}$ & $36,00 \mathrm{a}$ & $13,00 \mathrm{a}$ & $20,33 \mathrm{~b}$ & $26,00 \mathrm{a}$ & $24,50 \mathrm{a}$ \\
\hline & & & $20-40$ & $13,25 \mathrm{a}$ & $24,00 \mathrm{~b}$ & $11,50 \mathrm{~b}$ & $15,00 \mathrm{~b}$ & $23,50 \mathrm{a}$ & $18,00 \mathrm{~b}$ & $11,00 \mathrm{a}$ & $16,50 \mathrm{~b}$ & $24,00 \mathrm{a}$ & $15,75 \mathrm{a}$ \\
\hline \multirow{12}{*}{ 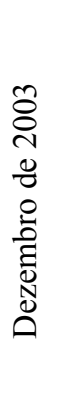 } & \multirow{6}{*}{ 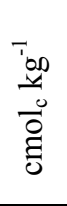 } & & $0-5$ & $1,01 \mathrm{a}$ & $1,69 \mathrm{a}$ & $2,29 \mathrm{a}$ & $0,52 \mathrm{a}$ & $2,04 \mathrm{a}$ & $0,31 \mathrm{a}$ & $0,98 \mathrm{a}$ & $0,70 \mathrm{a}$ & $0,76 \mathrm{a}$ & $1,25 \mathrm{a}$ \\
\hline & & \multirow[t]{3}{*}{$\mathrm{Ca}$} & $0-20$ & $0,51 \mathrm{ab}$ & $0,18 \mathrm{~b}$ & $0,66 \mathrm{~b}$ & $0,11 \mathrm{a}$ & $0,82 \mathrm{~b}$ & $0,12 \mathrm{a}$ & $0,17 \mathrm{~b}$ & $0,20 \mathrm{a}$ & $0,12 \mathrm{a}$ & $0,46 \mathrm{ab}$ \\
\hline & & & $20-40$ & $0,13 \mathrm{~b}$ & $0,03 \mathrm{~b}$ & $0,06 \mathrm{~b}$ & $0,03 \mathrm{a}$ & $0,19 \mathrm{~b}$ & $0,03 \mathrm{a}$ & $0,03 \mathrm{~b}$ & $0,03 \mathrm{a}$ & $0,07 \mathrm{a}$ & $0,06 \mathrm{~b}$ \\
\hline & & & $0-5$ & $0,28 \mathrm{a}$ & $0,42 \mathrm{a}$ & $0,42 \mathrm{a}$ & $0,21 \mathrm{a}$ & $0,53 \mathrm{a}$ & $0,12 \mathrm{a}$ & $0,29 \mathrm{a}$ & $0,20 \mathrm{a}$ & $0,27 \mathrm{a}$ & $0,33 \mathrm{a}$ \\
\hline & & \multirow[t]{2}{*}{$\mathrm{Mg}$} & $0-20$ & $0,14 \mathrm{ab}$ & $0,06 \mathrm{~b}$ & $0,17 \mathrm{~b}$ & $0,05 \mathrm{~b}$ & $0,25 \mathrm{~b}$ & $0,03 \mathrm{a}$ & $0,06 \mathrm{~b}$ & $0,05 \mathrm{ab}$ & $0,05 \mathrm{~b}$ & $0,15 \mathrm{~b}$ \\
\hline & & & $20-40$ & $0,09 \mathrm{~b}$ & $0,02 \mathrm{~b}$ & $0,03 \mathrm{~b}$ & $0,01 \mathrm{~b}$ & $0,08 \mathrm{c}$ & $0,02 \mathrm{a}$ & $0,02 \mathrm{~b}$ & $0,02 \mathrm{~b}$ & $0,03 \mathrm{~b}$ & $0,03 \mathrm{~b}$ \\
\hline & \multirow{6}{*}{ 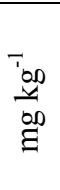 } & & $0-5$ & $101,88 \mathrm{a}$ & 104,38 a & 213,75 a & $63,13 \mathrm{a}$ & $110,00 \mathrm{a}$ & $69,38 \mathrm{a}$ & $56,88 \mathrm{a}$ & 41,25 a & $54,38 \mathrm{a}$ & $49,38 \mathrm{a}$ \\
\hline & & $\mathrm{P}$ & $0-20$ & $28,75 \mathrm{ab}$ & $31,88 \mathrm{ab}$ & $37,00 \mathrm{~b}$ & $20,00 \mathrm{a}$ & $37,50 \mathrm{ab}$ & $33,25 \mathrm{a}$ & $33,88 \mathrm{a}$ & $35,25 \mathrm{a}$ & $24,38 \mathrm{a}$ & $28,75 \mathrm{a}$ \\
\hline & & & $20-40$ & $3,88 \mathrm{~b}$ & $5,00 \mathrm{~b}$ & $5,13 \mathrm{~b}$ & $4,50 \mathrm{~b}$ & $3,38 \mathrm{~b}$ & $4,38 \mathrm{a}$ & $2,50 \mathrm{a}$ & $5,63 \mathrm{a}$ & $3,13 \mathrm{a}$ & $3,75 \mathrm{a}$ \\
\hline & & & $0-5$ & $26,72 \mathrm{a}$ & $60,29 \mathrm{a}$ & $31,37 \mathrm{a}$ & $37,01 \mathrm{a}$ & $35,54 \mathrm{a}$ & $46,08 \mathrm{a}$ & $19,61 \mathrm{a}$ & 36,76 a & $38,24 \mathrm{a}$ & $20,34 \mathrm{a}$ \\
\hline & & $\mathrm{K}$ & $0-20$ & $15,93 \mathrm{a}$ & $36,03 \mathrm{~b}$ & $18,38 \mathrm{ab}$ & $28,68 \mathrm{ab}$ & $14,71 \mathrm{~b}$ & $21,32 \mathrm{~b}$ & $9,07 \mathrm{ab}$ & $26,33 \mathrm{ab}$ & $17,89 \mathrm{~b}$ & $12,81 \mathrm{ab}$ \\
\hline & & & $20-40$ & $14,78 \mathrm{a}$ & $23,04 \mathrm{~b}$ & $10,84 \mathrm{~b}$ & $23,65 \mathrm{~b}$ & $6,62 \mathrm{~b}$ & $11,52 \mathrm{~b}$ & $5,64 \mathrm{~b}$ & $17,06 \mathrm{~b}$ & $11,76 \mathrm{~b}$ & $5,88 \mathrm{~b}$ \\
\hline
\end{tabular}

* Medias para cada elemento seguidas de mesma letra na coluna não diferem estatisticamente pelo teste de Tukey a $5 \%$ de probabilidade. $\mathrm{T}_{1}=(1540 \mathrm{~g}$ de $\mathrm{Ne} 1539 \mathrm{~g}$ de K$) ; \mathrm{T}_{2}=(1540 \mathrm{~g}$ de $\mathrm{N} \mathrm{e}$ $3591 \mathrm{~g}$ de K $) ; \mathrm{T}_{3}=(3591 \mathrm{~g}$ de N e $1539 \mathrm{~g}$ de K$) ; \mathrm{T}_{4}=(3591 \mathrm{~g}$ de N e $3591 \mathrm{~g}$ de K$) ; \mathrm{T}_{5}=(256 \mathrm{~g}$ de Ne $1539 \mathrm{~g}$ de K$) ; \mathrm{T}_{6}=(4874 \mathrm{~g}$ de N e $3591 \mathrm{~g}$ de K$) ; \mathrm{T}_{7}=(1540 \mathrm{~g} \mathrm{de} \mathrm{N}$ e $258 \mathrm{~g}$ de K$) ; \mathrm{T}_{8}=$ 
Os teores de potássio no solo aumentaram à medida que aumentou a fertilização com o $\mathrm{KCl}^{-}$. Todavia, apresentou as maiores concentrações nas camadas superficiais. A diminuição dos teores de $\mathrm{K}$ ao longo do perfil analizado, mostra que ocorreu pouca movimentação de íons na vertical. Para o solo em estudo, que apresenta baixa CTC efetiva e alto potencial de perdas por lixiviação, a fertirrigação se faz vantajosa, aumentando a eficiência no manejo desse nutriente.

Como era esperado os resultados da análise do perfil do solo revelaram que os nutrientes se concentraram em camadas mais superficiais $(0-5 \mathrm{~cm})$, por ser imediatamente mais próxima do local da aplicação dos nutrientes. Estes resultados se assemelham aos encontrados para o sistema de plantio direto, conforme constatou Schlindwein \& Anghinomi (2000).

A camada de $0-5 \mathrm{~cm}$ representa uma porção pequena da localização do volume de raízes do coqueiro. Além disso, os resultados apresentam alto índice de dispersão. Contudo, era esperado que os teores obtidos nessa camada representassem um valor próximo à média entre as duas primeiras camadas analisadas (0-5 e 0-20), o que não ocorreu. Os teores encontrados na camada de 0-20 cm, são os que mais se aproximam daqueles encontrados na camada 0-5 cm. Isso mostra a influência, embora pequena, da homogeneização da camada superficial $(0-5 \mathrm{~cm})$, com teores mais baixos deste nutriente nas camadas mais inferiores $(0-20 \mathrm{~cm})$. Nesse contexto, o potássio aplicado via fertirrigação, assume maior mobilidade no solo dentre os demais nutrientes, exceto o nitrogênio, tornando o efeito da diluição dos teores mais acentuado na amostragem. Esse comportamento favorece a absorção do $\mathrm{K}$ pela planta, considerando uma melhor exploração do solo pelo sistema radicular em diferentes camadas.

$\mathrm{Na}$ Figura 15 são representados os teores de potássio no solo nos diferentes períodos de amostragens, revelando uma variação na camada de 0-20 cm de 7,41\% a $53,22 \%$ menor em relação à de $0-5 \mathrm{~cm}$; e de $29,51 \%$ a $71,16 \%$ na camada de $20-40 \mathrm{~cm}$ menor em relação à de $0-5 \mathrm{~cm}$. A mistura das camadas com maior e menor teores de potássio no solo, apresentaram menores teores desse nutriente, determinando um decréscimo promovido pela diluição das camadas. 

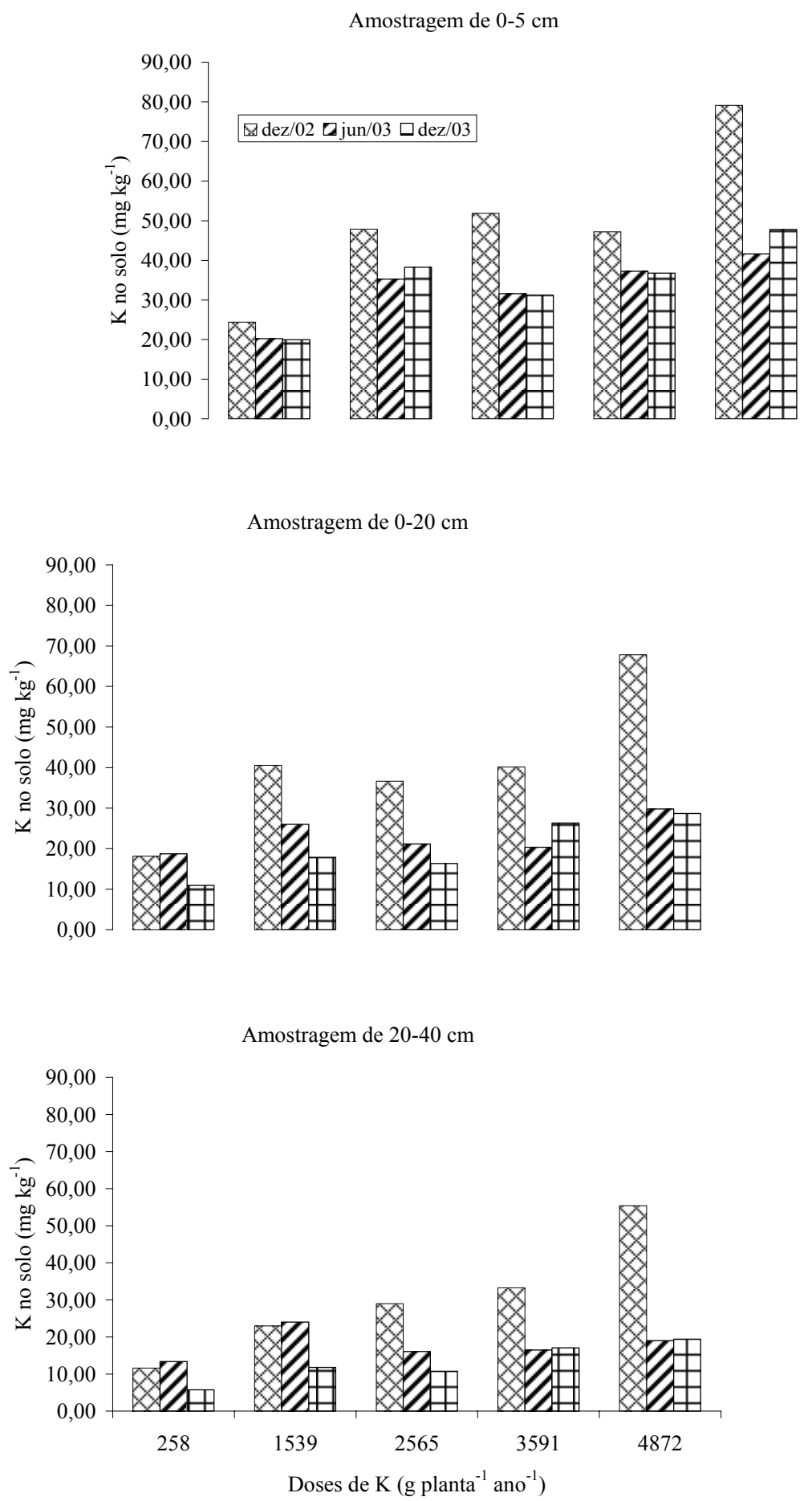

Figura 15 - Teor de K no solo a 0-5 cm, 0-20cm e $20-40 \mathrm{~cm}$, em função das doses de K aplicadas em três períodos de amostragem do solo 
As diferenças entre os teores de potássio, no período de estiagem (dezembro de 2002 e dezembro de 2003), tendem a serem menores à medida que se eleva a dose de $\mathrm{K}$ na fertirrigação; efeito contrário ocorre no período chuvoso (junho de 2003). Esta constatação se deve à maior lixiviação do nutriente no perfil do solo em períodos com alta intensidade de chuvas (junho de 2003), sendo tão logo reposto pela fertirrigação nas camadas superficiais, o que não ocorre com tanta intensidade nas camadas mais profundas. Pelo exposto, a camada de $0-20 \mathrm{~cm}$ representa melhor a interação entre a extração e a reposição de fertilizante nas condições de estudo.

A análise das médias para diferentes épocas de amostragem do solo na camada de 0-20 cm, vistas na Tabela 9, revela que as concentrações de $\mathrm{Ca}, \mathrm{Mg}, \mathrm{P}$ e $\mathrm{K}$ não sofreram diferenças significativas para a maioria dos tratamentos empregados nas dosagens de fertirrigação. Para doses em proporções acima de 80 \% de K em relação a $\mathrm{N}$, como está caracterizada no tratamento 5, ocorre diferenças significativas em relação às épocas de amostragem nas concentrações dos nutrientes avaliados nessa profundidade. Verifica-se que os teores dos nutrientes são encontrados em maiores quantidades no período chuvoso. Provavelmente devido a maior dissolução desses elementos no solo com o aumento de umidade.

Tabela 9. Médias* dos teores de $\mathrm{Ca}, \mathrm{Mg}, \mathrm{P}$ e $\mathrm{K}$ na profundidade de $0-20 \mathrm{~cm}$ de acordo com cada tratamento para a época chuvosa e seca (junho e dezembro de 2003, respectivamente)

\begin{tabular}{|c|c|c|c|c|c|c|c|c|c|c|c|}
\hline & \multirow{2}{*}{ Período } & \multicolumn{10}{|c|}{ Tratamento } \\
\hline & & 1 & 2 & 3 & 4 & 5 & 6 & 7 & 8 & 9 & 10 \\
\hline \multirow{2}{*}{$\mathrm{Ca}$} & chuva & $0,24 \mathrm{a}$ & $0,41 \mathrm{a}$ & $0,33 \mathrm{a}$ & $0,43 \mathrm{a}$ & $1,41 \mathrm{a}$ & $0,21 \mathrm{a}$ & $0,58 \mathrm{a}$ & $0,30 \mathrm{a}$ & $1,24 \mathrm{a}$ & $1,03 \mathrm{a}$ \\
\hline & seco & $0,51 \mathrm{a}$ & $0,18 \mathrm{a}$ & $0,66 \mathrm{a}$ & $0,11 \mathrm{a}$ & $0,82 \mathrm{~b}$ & $0,12 \mathrm{a}$ & $0,17 \mathrm{a}$ & $0,20 \mathrm{a}$ & $0,12 \mathrm{~b}$ & $0,46 \mathrm{~b}$ \\
\hline \multirow{3}{*}{$\mathrm{Mg}$} & chuva & $0,14 \mathrm{a}$ & $0,06 \mathrm{a}$ & $0,11 \mathrm{a}$ & $0,13 \mathrm{a}$ & $0,43 \mathrm{a}$ & $0,03 \mathrm{a}$ & $0,14 \mathrm{a}$ & $0,05 \mathrm{a}$ & $0,64 \mathrm{a}$ & $0,19 \mathrm{a}$ \\
\hline & seco & $0,14 \mathrm{a}$ & $0,06 \mathrm{a}$ & $0,17 \mathrm{a}$ & $0,05 \mathrm{a}$ & $0,25 \mathrm{~b}$ & $0,03 \mathrm{a}$ & $0,06 \mathrm{a}$ & $0,05 \mathrm{a}$ & $0,05 \mathrm{~b}$ & $0,15 \mathrm{a}$ \\
\hline & & 45,50 & 35,25 & 71,00 & 28,75 & 63,75 & 49,92 & 65,00 & 40,00 & 99,33 & 30,00 \\
\hline \multirow{4}{*}{$\mathrm{P}$} & chuva & a & $\mathrm{a}$ & $\mathrm{a}$ & $\mathrm{a}$ & $\mathrm{a}$ & a & $\mathrm{a}$ & $\mathrm{a}$ & $\mathrm{a}$ & $\mathrm{a}$ \\
\hline & & 28,75 & 31,88 & 37,00 & 20,00 & 37,50 & 33,25 & 33,88 & 35,25 & 24,38 & 28,75 \\
\hline & seco & $\mathrm{a}$ & $\mathrm{a}$ & $\mathrm{b}$ & $\mathrm{a}$ & b & $\mathrm{a}$ & $\mathrm{b}$ & $\mathrm{a}$ & b & $\mathrm{a}$ \\
\hline & & 14,75 & 28,75 & 20,25 & 24,67 & 28,50 & 36,00 & 13,00 & 20,33 & 26,00 & 24,50 \\
\hline \multirow{3}{*}{ K } & chuva & $\mathrm{a}$ & $\mathrm{a}$ & $\mathrm{a}$ & $\mathrm{a}$ & a & $\mathrm{a}$ & $\mathrm{a}$ & $\mathrm{a}$ & $\mathrm{a}$ & $\mathrm{a}$ \\
\hline & & 15,93 & 36,03 & 18,38 & 28,68 & 14,71 & 21,32 & & 26,33 & 17,89 & 12,80 \\
\hline & seco & $\mathrm{a}$ & a & $\mathrm{a}$ & a & b & b & $9,07 \mathrm{a}$ & $\mathrm{a}$ & $\mathrm{a}$ & $\mathrm{a}$ \\
\hline
\end{tabular}

*Médias para cada elemento seguidas de mesma letra na coluna não diferem estatisticamente pelo teste de Tukey a $5 \%$ de probabilidade. $\mathrm{T}_{1}=(1540 \mathrm{~g}$ de N e $1539 \mathrm{~g}$ de $\mathrm{K}) ; \mathrm{T}_{2}=(1540 \mathrm{~g}$ de $\mathrm{N}$ e $3591 \mathrm{~g}$ de $\mathrm{K}) ; \mathrm{T}_{3}=$ (3591 $\mathrm{g}$ de N e $1539 \mathrm{~g}$ de $\mathrm{K}) ; \mathrm{T}_{4}=(3591 \mathrm{~g}$ de N e $3591 \mathrm{~g}$ de $\mathrm{K}) ; \mathrm{T}_{5}=(256 \mathrm{~g}$ de N e $1539 \mathrm{~g}$ de $\mathrm{K}) ; \mathrm{T}_{6}=$ (4874 g de N e $3591 \mathrm{~g}$ de $\mathrm{K}) ; \mathrm{T}_{7}=(1540 \mathrm{~g}$ de N e $258 \mathrm{~g}$ de $\mathrm{K}) ; \mathrm{T}_{8}=(3591 \mathrm{~g}$ de N e $4872 \mathrm{~g}$ de $\mathrm{K}) ; \mathrm{T}_{9}=$ $(2565 \mathrm{~g}$ de N e $2565 \mathrm{~g}$ de $\mathrm{K}) ; \mathrm{T}_{10}=(256 \mathrm{~g}$ de N e $258 \mathrm{~g}$ de $\mathrm{K})$ 


\subsubsection{Características químicas}

Com base no item anterior discutir-se-ão os resultados encontrados na análise química da camada de $0-20 \mathrm{~cm}$ para o $6^{\circ}$ e $7^{\circ}$ ano de cultivo. Na avaliação química do $6^{\circ}$ ano de cultivo são apresentados os teores dos nutrientes encontrados em dezembro de 2002. Já na avaliação do $7^{\circ}$ ano, os nutrientes foram amostrados em duas épocas, junho e dezembro de 2003, correspondentes aos períodos de maior e menor freqüência de chuvas, respectivamente. Segundo esse enfoque, na Tabela 10, é apresentado o resumo da análise de variância para macronutrientes encontrados no solo em relação aos dois anos de estudo de acordo com as doses de N e K. De modo geral, a concentração química do solo foi afetada principalmente pelos níveis de $\mathrm{N}$ aplicados na fertirrigação. As doses de potássio tiveram sua influência diminuída, em relação aos nutrientes avaliados exceto $\mathrm{K}$ e $\mathrm{Na}$ no solo, ao longo do período de cultivo para todas as coletas realizadas.

Os teores dos elementos ( $\mathrm{Al}, \mathrm{Ca}, \mathrm{Mg}, \mathrm{P}, \mathrm{K}$ e $\mathrm{Na}$ ) no solo apresentaram uma variação muito alta. O coeficiente de variação $(\mathrm{CV})$ observado no $2^{\circ}$ ano (junho e dezembro de 2003) apresentou-se maior do que o observado no $1^{\circ}$ ano (dezembro de 2002) de estudo para os teores de $\mathrm{Al}, \mathrm{Ca}, \mathrm{Mg}$ e $\mathrm{K}$. Este resultado confirma a hipótese, já discutida anteriormente, de que esta alta variação esteja relacionada à pontos de alta concentração desses nutrientes. Houve nesta camada (0-20), além do efeito residual das doses aplicadas no primeiro ano de estudo, reaplicações a cada 6 meses daqueles nutrientes aplicados a "lanço".

Um dos efeitos da aplicação excessiva do nitrogênio no solo foi o aumento da acidez. Os valores de $\mathrm{pH}$ do solo apresentaram variações significativas entre os tratamentos. No primeiro ano de estudo, o nitrogênio em relação ao potássio teve maior efeito sobre esse fator no solo (Figura 16, A).

Como o $\mathrm{pH}$ do solo depende, fundamentalmente, do material de origem, grau de intemperização e do manejo de solo (Wolkweiss, 1989) a variação pode estar relacionada ao manejo inicial realizado no solo, onde houve incorporação do calcário, visando que os efeitos da freqüência de fertirrigação fossem minimizados. 
Tabela 10. Análise de variância dos teores de $\mathrm{pH}, \mathrm{Al}, \mathrm{Ca}, \mathrm{Mg}, \mathrm{P}, \mathrm{K}$ e $\mathrm{Na}$ para profundidade de $0-20 \mathrm{~cm}$ de acordo com cada amostragem (dezembro de 2002, junho e dezembro de 2003, respectivamente)

\begin{tabular}{|c|c|c|c|c|c|c|c|}
\hline \multirow{3}{*}{ Fonte de variação } & $\mathrm{pH}$ & $\mathrm{Al}$ & $\mathrm{Ca}$ & $\mathrm{Mg}$ & $\mathrm{P}$ & $\mathrm{K}$ & $\mathrm{Na}$ \\
\hline & \multicolumn{7}{|c|}{ Valores de F } \\
\hline & \multicolumn{7}{|c|}{ Dezembro de 2002} \\
\hline Efeito linear do $\mathrm{N}$ & $26,35 * *$ & $11,91 * *$ & $5,53^{\wedge}$ & $9,42 * *$ & $22,9 * *$ & $223,6 * *$ & ns \\
\hline Efeito quadrático do $\mathrm{N}$ & $3,81^{\wedge}$ & $3,27^{\wedge}$ & ns & ns & ns & $125,5 * *$ & ns \\
\hline Efeito linear do $\mathrm{K}$ & $4,72^{*}$ & $9,56^{* *}$ & $6,47 *$ & $3,35^{\wedge}$ & ns & $33,7 * *$ & $3,04^{\boldsymbol{\Lambda}}$ \\
\hline Efeito quadrático do $\mathrm{K}$ & ns & ns & ns & ns & $7,30 *$ & $47,6 * *$ & ns \\
\hline Efeito linear da $N^{*} \mathrm{~K}$ & ns & ns & ns & ns & ns & ns & ns \\
\hline \multirow[t]{2}{*}{$\mathrm{CV}$} & 9,45 & 39,8 & 81,9 & 63,9 & 41,3 & 19,23 & 44,44 \\
\hline & \multicolumn{7}{|c|}{ Junho de 2003} \\
\hline Efeito linear do $\mathrm{N}$ & $43,9 * *$ & $39,5 * *$ & $25,9 * *$ & $35,9 * *$ & ns & ns & $54,4 * *$ \\
\hline Efeito quadrático do $\mathrm{N}$ & ns & ns & ns & $4,8^{*}$ & ns & $15,5^{* *}$ & ns \\
\hline Efeito linear do $\mathrm{K}$ & ns & ns & ns & ns & $5,14 *$ & $7,0 *$ & $31,6^{*}$ \\
\hline Efeito quadrático do $\mathrm{K}$ & ns & ns & $3,13^{\wedge}$ & $52,2 * *$ & $4,71^{*}$ & $6,2^{*}$ & ns \\
\hline Efeito linear da $\mathrm{N}^{*} \mathrm{~K}$ & ns & ns & $3,25^{\mathbf{\Lambda}}$ & $39,6 * *$ & ns & ns & $16,3^{* *}$ \\
\hline \multirow[t]{2}{*}{$\mathrm{CV}$} & 7,81 & 48,8 & 53,1 & 36,55 & 42,5 & 28,12 & 23,2 \\
\hline & \multicolumn{7}{|c|}{ Dezembro de 2003} \\
\hline Efeito linear do $\mathrm{N}$ & $13,4 * *$ & $8,4 * *$ & $4,2^{*}$ & $8,7^{* *}$ & ns & $9,9 * *$ & $38,2 * *$ \\
\hline Efeito quadrático do $\mathrm{N}$ & ns & $4,3 *$ & ns & ns & ns & ns & $8,4 * *$ \\
\hline Efeito linear do $\mathrm{K}$ & ns & ns & ns & ns & ns & $35,2 * *$ & ns \\
\hline Efeito quadrático do $\mathrm{K}$ & ns & ns & ns & ns & ns & ns & $6,7 *$ \\
\hline Efeito linear da $\mathrm{N}^{*} \mathrm{~K}$ & ns & ns & ns & ns & $4,4^{*}$ & $4,05^{\boldsymbol{\Lambda}}$ & $4,6^{*}$ \\
\hline $\mathrm{CV}$ & 7,92 & 46,9 & 111,0 & 87,8 & 37,27 & 30,26 & 19,15 \\
\hline
\end{tabular}

$\mathrm{O}$ fornecimento de nitrogênio na forma de uréia $\left[\mathrm{CO}\left(\mathrm{NH}_{2}\right)_{2}\right]$ resulta em amônio, bicarbonato e hidroxila que por sua vez reagem com átomos de hidrogênio o que, em parte, neutraliza um pouco a acidez que, mais tarde, é gerada pela nitrificação. $O$ processo de nitrificação no solo, libera íons $\mathrm{H}^{+}$. Estes disponibilizam o $\mathrm{Al}^{+3}$ para a solução do solo e diminuem a disponibilidade do potássio, do cálcio, do magnésio e do enxofre. $\mathrm{O}$ nitrato $\left(\mathrm{NO}_{3}{ }^{-}\right)$também acidifica o solo, pois promove a lixiviação das bases 
$\left(\mathrm{K}^{+}, \mathrm{Ca}^{+2}\right.$ e $\left.\mathrm{Mg}^{+2}\right)$, que são substituídas pelo $\mathrm{H}^{+}$. O nitrato e as bases movem-se juntos. $\mathrm{A}$ medida que as bases são removidas e substituídas pelo hidrogênio, o solo torna-se mais ácido.

\section{(A)}

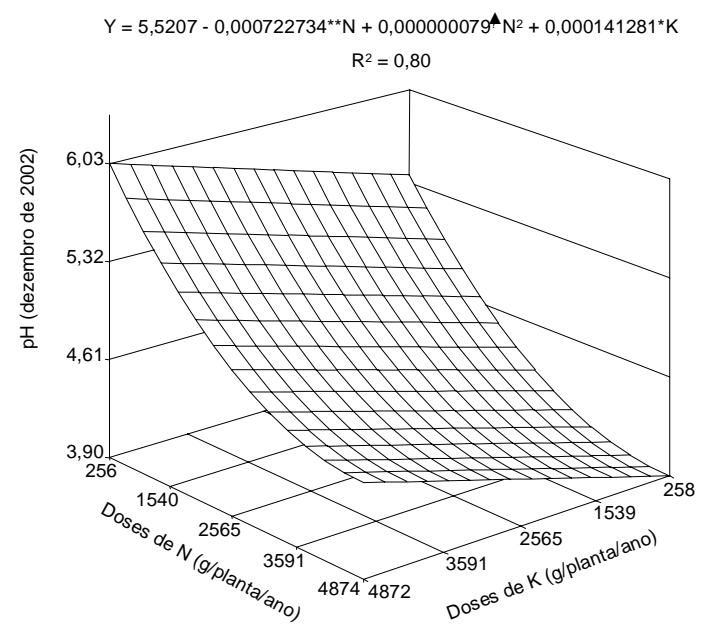

(B)

(C)
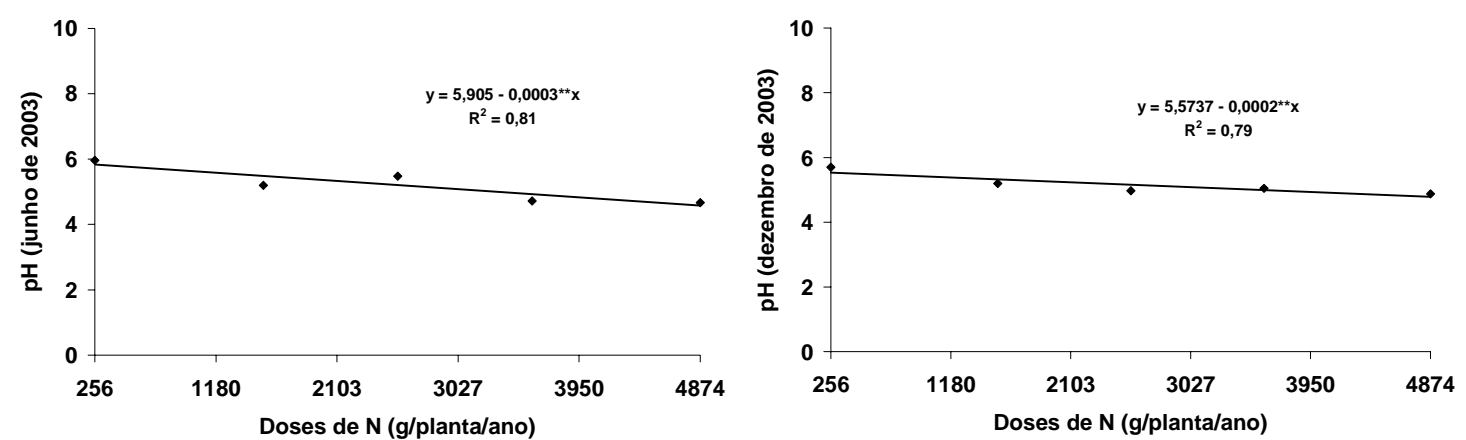

Figura 16 - Valor de pH no solo no $1^{\circ}$ e $2^{\circ}$ ano de estudo, em função das doses de nitrogênio aplicadas na fertirrigação

$\mathrm{O}$ aumento no teor de nitrogênio das doses de fertirrigação deixa claro uma tendência à diminuição do $\mathrm{pH}$ do solo tendo uma maior correlação no período de maior freqüência de chuvas, para o segundo ano (Figura 16, B), com decréscimo de 5,5\% a 
cada incremento nas doses de N. A partir $1540 \mathrm{~g} \mathrm{planta}^{-1}$ ano $^{-1}$ de nitrogênio, no segundo ano de estudo (junho e dezembro de 2003), o pH do solo apresenta a tendência de estabilização em torno de 5,00 (Figura 16, B e C). Acredita-se que isso tenha ocorrido diante do acúmulo e da manutenção dos teores de $\mathrm{N}$ no solo durante todo o período de estudo. Contudo, o abaixamento do pH observado pode estar, em grande parte, também relacionado ao efeito da localização do sistema radicular, devido à absorção de nutrientes pelas raízes, aumentando a atividade dos íons hidrogênio.

$\mathrm{Na}$ Figura 17 é mostrada as superfícies de resposta dos teores de $\mathrm{Ca}, \mathrm{Mg}, \mathrm{P}$ e $\mathrm{K}$ no solo em função das doses de nitrogênio e potássio aplicadas no primeiro ano de estudo, referente ao $6^{\circ}$ ano de cultivo. As superfícies de resposta para Ca (Figura 17, A) e $\operatorname{Mg}$ (Figura 17, B) deste ano não revelam um bom ajuste estatístico $\left(\mathrm{r}^{2}=0,53\right)$. Entretanto, deixam claro uma diminuição dos teores de $\mathrm{Ca}$ e $\mathrm{Mg}$ no solo em relação ao início do experimento (Tabela 4); com doses de potássio favorecendo o incremento desses nutrientes ( $\mathrm{Ca}$ e $\mathrm{Mg}$ ) no solo e, de modo contrário quando houve incremento de nitrogênio no solo.

De acordo com Blanco (2004) a alta freqüência de aplicação de fertilizantes pela fertirrigação pode ter contribuído para manter a concentração de $\mathrm{NH}_{4}$ na solução do solo em níveis mais elevados do que pela adubação convencional, favorecendo a ocorrência do efeito competitivo entre $\mathrm{NH}_{4}$ e Ca. As superfícies de resposta de resposta para o fósforo (Figura 17, C) e o potássio (Figura 17, D) apresentaram melhores ajustes, $\mathrm{r}^{2}=$ 0,62 e 0,83 , respectivamente, reafirmando a conseqüência da adubação, já que o fósforo era reposto semestralmente e o potássio adicionado em doses crescentes e com alta freqüência.

Como já era esperado, o aumento nas doses de nitrogênio favoreceu ao incremento dos teores de fósforo no solo. Este fato confirma que o fósforo está relacionado com o pH do solo, que por sua vez sofreu influência direta das doses de N. Como a diminuição do pH no solo numa faixa de 4,5 a 6,0 aumenta a dissociação do ácido ortofosfórico, as maiores doses de $\mathrm{N}$ aplicadas disponibilizaram maiores quantidades de fósforo. Sob condições de alta temperatura e umidade do solo, há uma aceleração do processo de nitrificação e, conseqüentemente, uma redução gradativa do 
pH do solo, a qual é acelerada com a aplicação contínua de fertilizantes amoniacais (Tisdale et al., 1993).

(A)

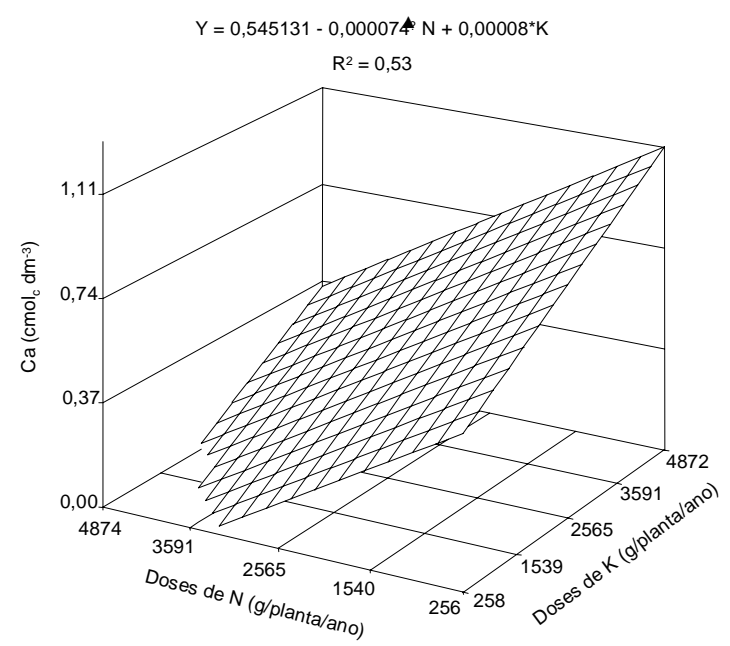

(C)

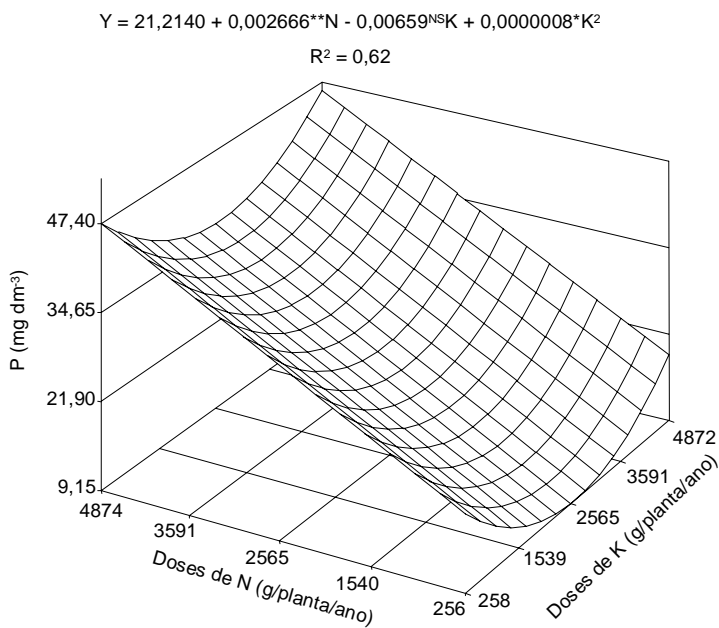

(B)

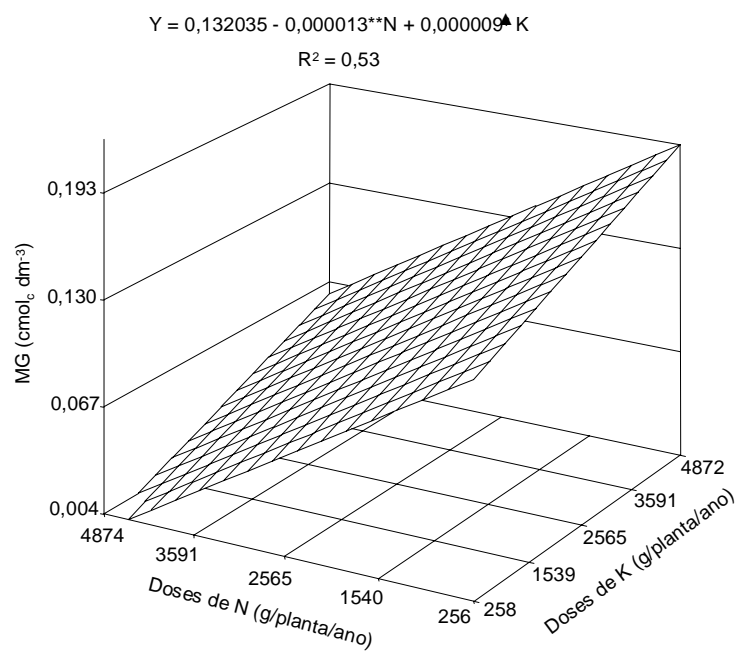

(D)

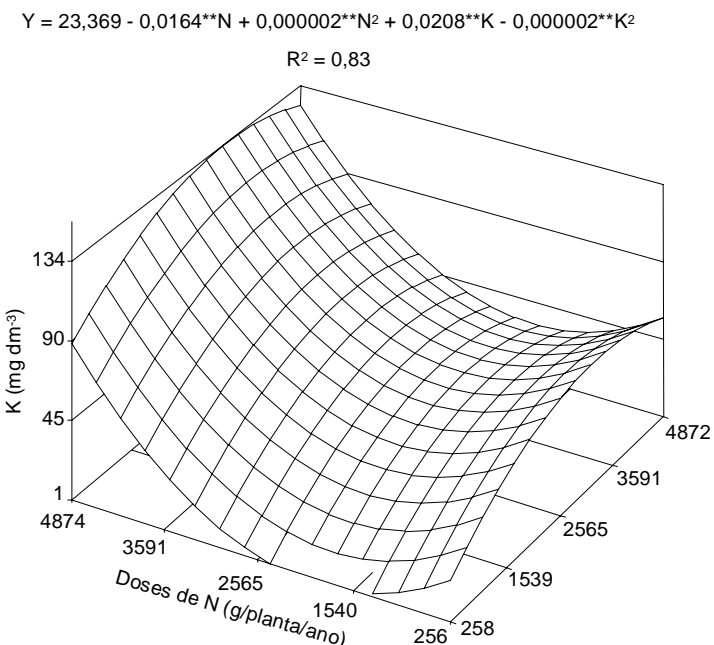

Figura 17 - Concentração de Ca (A), $\mathrm{Mg}$ (B), P (C) e K (D) no solo em função das doses de nitrogênio e potássio aplicadas sob fertirrigação no $1^{\circ}$ ano de estudo

Os teores de potássio encontrados no solo sofreram influência das doses de $\mathrm{N}$ e de K. Doses crescentes de potássio tiveram efeito linear no aumento da concentração 
desse nutriente no solo. Já o nitrogênio passou a apresentar influência nesse fator para doses de $\mathrm{N}$ acima de $2565 \mathrm{~g}_{\text {planta }}{ }^{-1}$ ano $^{-1}$. Observa-se também que as doses de nitrogênio quando balanceadas com doses de potássio numa proporção semelhante, fazem com que os teores de potássio atinjam valores máximos. Isso deixa clara a importância do equilíbrio entre cargas iônicas no solo. Em geral, a quantidade de $\mathrm{K}$ necessária para aumentar o teor de $\mathrm{K}$ trocável no solo em $1 \mathrm{mmol}_{\mathrm{c}} \mathrm{dm}^{-3}$ pode variar de 44 a $1967 \mathrm{~kg} \mathrm{ha}^{-1}$, dependendo do tipo de solo, sendo esta diferença devida, em parte, à variação do potencial de fixação de K entre os solos (Tisdale et al., 1993).

Os teores de nutrientes presentes nas análises de fertilidade realizadas no segundo ano de estudo, referente ao $7^{\circ}$ ano de cultivo, apresentaram maior concentrações de $\mathrm{Ca}, \mathrm{Mg}$ e $\mathrm{P}$ no solo no período de maior intensidade das chuvas, exceto o potássio que apresentou certa estabilização para as coletas realizadas. Como era esperado, as concentrações de $\mathrm{K}$ foram proporcionais às doses de $\mathrm{K}$ aplicadas na fertirrigação, embora tenha havido interação das doses de $\mathrm{N}$ e K para potássio no solo na última coleta (Figura $18 \mathrm{C}$ ).

As superfícies de resposta para Ca (Figura 18, A) e Mg (Figura 18, B) tiveram mesmo comportamento do ano anterior, quando não revelaram um bom ajuste estatístico. Este resultado, já discutido anteriormente, está relacionado provavelmente a amostragens em pontos de alta concentração desses nutrientes. Contudo, expõe principalmente o efeito das doses de nitrogênio ocasionando uma redução dos teores de $\mathrm{Ca}$ e $\mathrm{Mg}$ com o incremento das doses de N. Houve ainda uma diminuição desses teores no solo em relação ao $6^{\circ}$ ano de cultivo. O fósforo (Figuras 18 D) sofreu efeito decrescente e significativo das doses de potássio a partir de $2565 \mathrm{~g} \mathrm{planta}^{-1}$ ano $^{-1}$ não se evidenciando efeito do $\mathrm{N}$ isoladamente para esse fator. Ao longo do tempo de estudo, o potássio apresentou tendência a estabilização na concentração dos teores no solo (Figura 19 A). Isso está claramente representado nas Figuras 19 (B e C) diante da suavidade de declive das superfícies de resposta. A concentração ótima de $\mathrm{K}$ na solução do solo varia entre 10 e $60 \mathrm{mg} \mathrm{L}^{-1}$, dependendo da cultura, estrutura e fertilidade do solo e do seu suprimento hídrico (Tisdale et al.,1993). As concentrações observadas estiveram sempre 
próximas, dentro ou acima deste limite, podendo-se afirmar que a concentração de $\mathrm{K}$ foi suficiente durante todo o período de cultivo, em doses acima de $1539 \mathrm{~g} \mathrm{planta}^{-1}$ ano $^{-1}$.
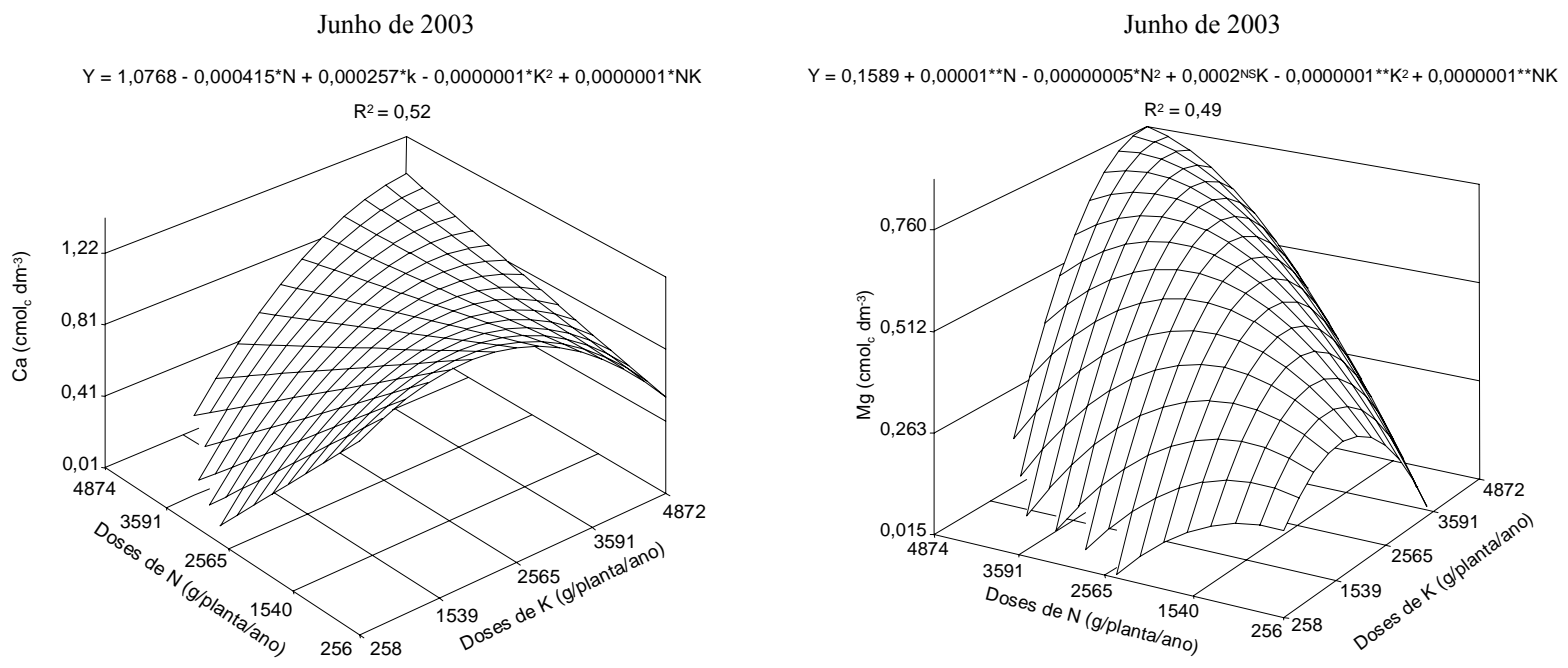

Junho de 2003

junho de 2003
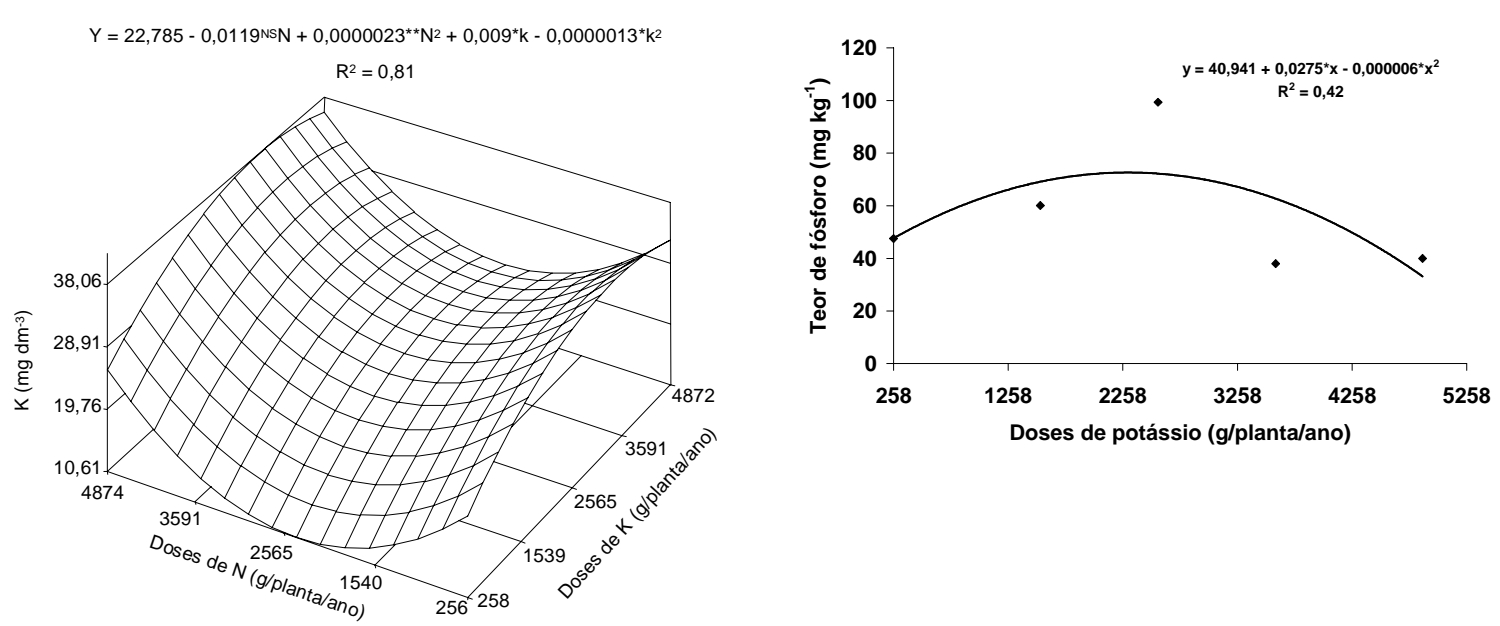

Figura 18 - Concentração de Ca (A), $\mathrm{Mg}$ (B), K (C) e P (D) no solo em função das doses de nitrogênio e potássio aplicadas sob fertirrigação no $2^{\circ}$ ano de estudo em período de maior intensidade de chuva (junho de 2003) 
(A)

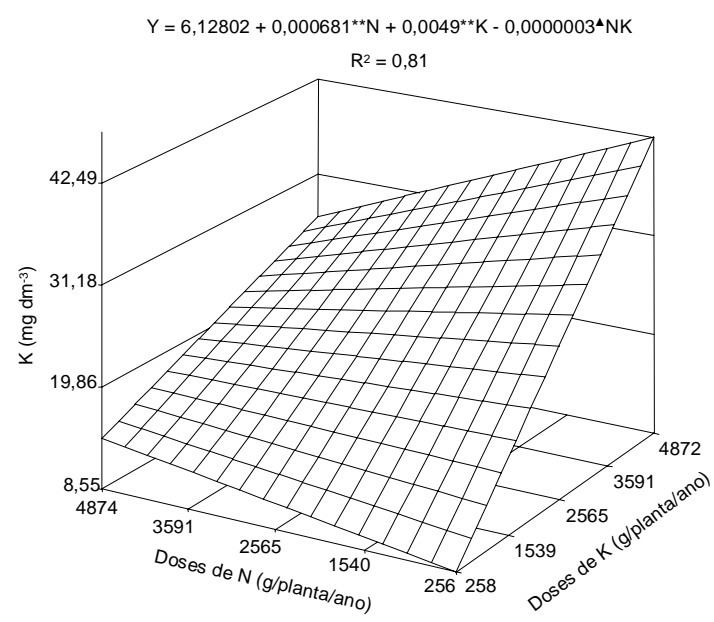

(B)

(C)
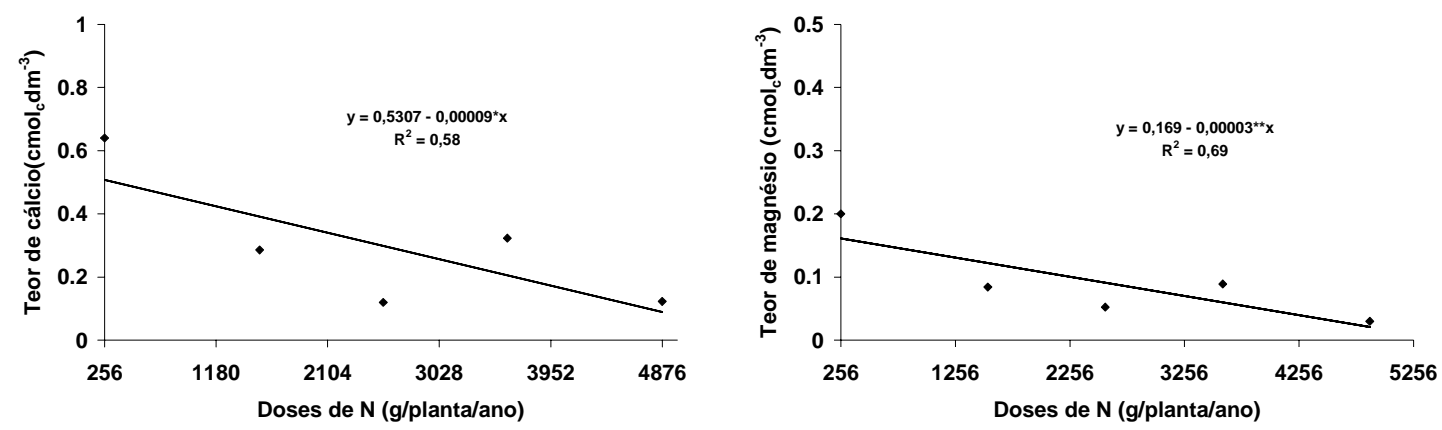

Figura 19 - Concentração de K (A), Ca (B) e Mg (C) no solo em função das doses de nitrogênio e potássio aplicadas sob fertirrigação no $2^{\circ}$ ano de estudo em período de menor intensidade de chuva (dezembro de 2003) 


\subsection{Estado nutricional}

A análise foliar tem sido largamente utilizada para se avaliar o estado nutricional das plantas, em períodos definidos de sua vida, tendo por base a hipótese de que existe uma ralação causal entre a absorção dos nutrientes pelas raízes e a produtividade da cultura. Isso proporciona o estabelecimento de recomendações de níveis adequados desses nutrientes para cada cultura. Vitti et al. (2001) define que as folhas, como regra geral, refletem melhor o estado nutricional, isto é, respondem mais às variações no suprimento de nutriente, seja pelo solo, seja pelo adubo.

$\mathrm{O}$ estado nutricional do coqueiro foi analisado concomitantemente com as análises de solo, para os dois anos de estudo respectivamente, ou seja $6^{\circ}$ e $7^{\circ}$ ano de cultivo. Foram analisadas as concentrações de nitrogênio $(\mathrm{N})$, fósforo $(\mathrm{P})$, potássio $(\mathrm{K})$, cálcio $(\mathrm{Ca})$, magnésio $(\mathrm{Mg})$, sódio $(\mathrm{Na})$, cloro $(\mathrm{Cl})$, boro $(\mathrm{B})$, zinco $(\mathrm{Zn})$, cobre $(\mathrm{Cu})$, ferro $(\mathrm{Fe})$ e manganês $(\mathrm{Mn})$.

$\mathrm{Na}$ avaliação nutricional do $6^{\circ}$ ano de cultivo são apresentados os teores dos nutrientes encontrados em dezembro de 2002. Já na avaliação do $7^{\circ}$ ano, os nutrientes foram amostrados em duas épocas, quais sejam, junho e dezembro de 2003, correspondentes aos períodos de maior e menor freqüência de chuvas, respectivamente.

A análise de variância para a concentração dos nutrientes nas folhas do coqueiro, de acordo com as doses de $\mathrm{N}$ e $\mathrm{K}$, para os dois anos de estudo ( $6^{\circ}$ e $7^{\circ}$ ano de produção) é apresentada na Tabela 11.

A análise para o $6^{\circ}$ ano de produção mostrou efeito significativo das doses de $\mathrm{N}$ em relação as concentrações de $\mathrm{P}$ e $\mathrm{K}(\mathrm{P} \leq 0,05)$ e de $\mathrm{Mg}$ e $\mathrm{Na}(\mathrm{P} \leq 0,01)$. Já as doses de $\mathrm{K}$ expressaram efeito altamente significativo $(\mathrm{P} \leq 0,01)$ para a maioria das concentrações dos macronutrientes, salvo exceção de N, P e Ca. As concentrações dos micronutrientes $\mathrm{Zn}$ e $\mathrm{Mn}$ foram influenciadas pelas doses de $\mathrm{N}$, já as doses de $\mathrm{K}$ tiveram maior efeito sobre o B e o Fe. Não houve efeito de interação entre as doses de $\mathrm{N}$ e $\mathrm{K}$ nas concentrações dos nutrientes avaliados. 
Tabela 11. Resumo da análise de variância para concentração de macronutrientes nas folhas do coqueiro de acordo com a idade de cultivo (dezembro de 2002, junho e dezembro de 2003, respectivamente)

\begin{tabular}{|c|c|c|c|c|c|c|c|c|c|c|c|c|}
\hline $\begin{array}{l}\text { Fonte de } \\
\text { variação }\end{array}$ & \multicolumn{12}{|c|}{ Valores de F } \\
\hline & \multicolumn{12}{|c|}{$6^{\circ}$ ano (dezembro de 2002 ) } \\
\hline Efeito linear do $\mathrm{N}$ & ns & $\mathrm{ns}$ & $41,8^{*}$ & ns & $53,02^{* *}$ & $30,3^{* *}$ & $\mathrm{~ns}$ & $\mathrm{~ns}$ & $7,86^{* *}$ & $\mathrm{~ns}$ & $\mathrm{~ns}$ & $12,85^{* *}$ \\
\hline $\begin{array}{l}\text { Efeito quadrático } \\
\text { do } \mathrm{N}\end{array}$ & ns & $4,82^{*}$ & ns & ns & $\mathrm{ns}$ & ns & $\mathrm{ns}$ & ns & $7,8^{* *}$ & ns & ns & ns \\
\hline Efeito linear do $\mathrm{K}$ & ns & $\mathrm{ns}$ & $88,8^{* *}$ & ns & $34,52 * *$ & $31,32 * *$ & $24,65 * *$ & $\mathrm{~ns}$ & ns & ns & $3,2^{\mathbf{\Lambda}}$ & $\mathrm{ns}$ \\
\hline $\begin{array}{l}\text { Efeito quadrático } \\
\text { do K }\end{array}$ & ns & ns & $9,82^{*}$ & ns & ns & ns & $7,31^{*}$ & $5,41^{*}$ & ns & $\mathrm{ns}$ & $3,42^{\wedge}$ & ns \\
\hline Efeito linear $\mathrm{N}^{*} \mathrm{~K}$ & ns & ns & ns & $\mathrm{ns}$ & ns & ns & $\mathrm{ns}$ & $\mathrm{ns}$ & ns & ns & ns & ns \\
\hline \multirow[t]{2}{*}{$\mathrm{CV}$} & 10,89 & 12,77 & 13,32 & 22,63 & 13,61 & 17,45 & 24,21 & 23,14 & 15,98 & 92,0 & 10,62 & 21,23 \\
\hline & \multicolumn{12}{|c|}{$7^{\mathrm{o}}$ ano (junho de 2003 ) } \\
\hline Efeito linear do $\mathrm{N}$ & & $2,93^{\wedge}$ & $87,67^{* *}$ & & $146,0^{* *}$ & & $6,03 *$ & $7,45^{*}$ & $9,16^{* *}$ & & & $74,82^{* *}$ \\
\hline $\begin{array}{l}\text { Efeito quadrático } \\
\text { do } \mathrm{N}\end{array}$ & & $8,22 * *$ & ns & ns & $\mathrm{ns}$ & ns & ns & ns & ns & $3,73^{\wedge}$ & ns & ns \\
\hline Efeito linear do $\mathrm{K}$ & ns & ns & $174,0^{* *}$ & ns & $103,86^{* *}$ & $63,36^{* *}$ & $4,32 *$ & $5,32 *$ & $\mathrm{~ns}$ & ns & ns & $\mathrm{ns}$ \\
\hline $\begin{array}{l}\text { Efeito quadrático } \\
\text { do K }\end{array}$ & $6,93^{*}$ & ns & $45,25 * *$ & $\mathrm{~ns}$ & $29,55^{* *}$ & $9,76^{* *}$ & ns & ns & ns & ns & ns & ns \\
\hline Efeito linear $\mathrm{N}^{*} \mathrm{~K}$ & ns & ns & ns & ns & ns & ns & ns & $7,22 *$ & $5,47^{*}$ & $3,94^{\wedge}$ & $5,67^{*}$ & ns \\
\hline \multirow[t]{2}{*}{$\mathrm{CV}$} & 8,08 & 10,34 & 9,57 & 14,88 & 9,58 & 23,88 & 24,7 & 14,93 & 11,69 & 39,78 & 19,9 & 19,64 \\
\hline & \multicolumn{12}{|c|}{$7^{\mathrm{o}}$ ano (dezembro de 2003 ) } \\
\hline Efeito linear do $\mathrm{N}$ & ns & ns & $29,34 * *$ & ns & $99,19^{* *}$ & $16,38^{* *}$ & ns & $4,69^{*}$ & ns & ns & ns & $144,05^{* *}$ \\
\hline $\begin{array}{l}\text { Efeito quadrático } \\
\text { do N }\end{array}$ & ns & $7,87 * *$ & $11,93^{* *}$ & $\mathrm{~ns}$ & $4,31^{*}$ & $\mathrm{~ns}$ & $\mathrm{~ns}$ & $\mathrm{~ns}$ & $\mathrm{~ns}$ & $\mathrm{~ns}$ & $\mathrm{~ns}$ & $\mathrm{~ns}$ \\
\hline Efeito linear do $\mathrm{K}$ & ns & ns & $122,57^{* *}$ & $4,0^{\wedge}$ & $26,25 * *$ & $9,29^{* *}$ & ns & $8,49^{* *}$ & $\mathrm{~ns}$ & ns & $\mathrm{ns}$ & ns \\
\hline $\begin{array}{l}\text { Efeito quadrático } \\
\text { do K }\end{array}$ & $4,93^{*}$ & $\mathrm{~ns}$ & $\mathrm{~ns}$ & $4,58^{*}$ & $\mathrm{~ns}$ & $\mathrm{~ns}$ & $\mathrm{~ns}$ & ns & $13,97^{* *}$ & $4,6^{*}$ & $2,95^{\wedge}$ & $\mathrm{ns}$ \\
\hline Efeito linear $N^{*} \mathrm{~K}$ & ns & ns & ns & ns & ns & $6,07^{*}$ & ns & ns & $3,54^{\wedge}$ & $4,37^{*}$ & ns & $\mathrm{ns}$ \\
\hline $\mathrm{CV}$ & 4,35 & 5,72 & 11,33 & 15,69 & 11,22 & 20,36 & 10,26 & 15,40 & 14,77 & 58,55 & 18,59 & 18,44 \\
\hline
\end{tabular}

Não foram observados efeitos nos teores de $\mathrm{N}$, no $6^{\circ}$ ano de cultivo, com o aumento das doses de $\mathrm{N}$, como era esperado. Na avaliação do sétimo ano as doses de $\mathrm{K}$ favoreceram ao aumento dos teores desse nutriente nas folhas do coqueiro. Contudo, esse aumento não se mostrou expressivo tanto na diferenciação entre as doses quanto entre as épocas avaliadas (Figura 20). Entretanto, se comprova uma maior eficiência de absorção desse nutriente pela planta em junho, que provavelmente foi devida às 
condições ambientais mais favoráveis do período. A concentração de $\mathrm{N}$ encontrada durante esses dois anos de produção se mostrou satisfatória em relação aos níveis críticos estabelecidos pela literatura (Kanapathy, 1971; citado por Camboim Neto, 2002) para o elemento na folha 14 do coqueiro. Em coqueiro híbrido, Lins (2000) verificou aumento na concentração de $\mathrm{N}$ na folha mesmo na ausência da adubação nitrogenada, por conseqüência da cobertura do solo com leguminosa, não havendo resposta à aplicação de uréia para as variáveis de produção. Em trabalho conduzido com dendezeiro, Rodrigues (1998) observou que o teor de $\mathrm{N}$ na folha variou em função da nutrição fosfatada que contribuiu para elevação dos teores. Provavelmente as aplicações semestrais com adubação orgânica favoreceram à manutenção de níveis satisfatórios de $\mathrm{N}$ encontrados neste trabalho.

$7^{\mathrm{o}}$ ano (junho de 2003)

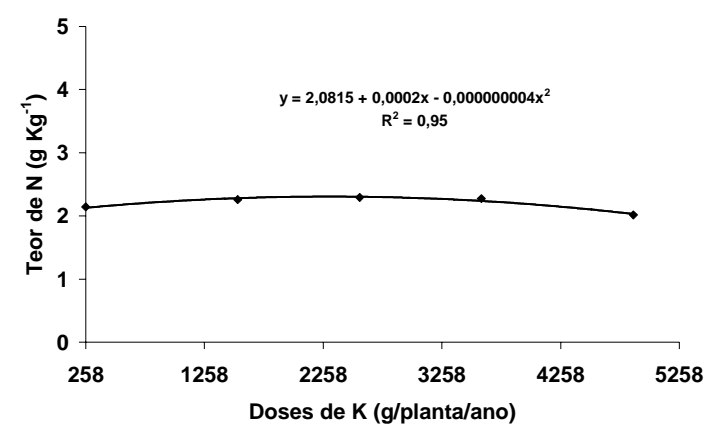

$7^{\circ}$ ano (dezembro de 2003)

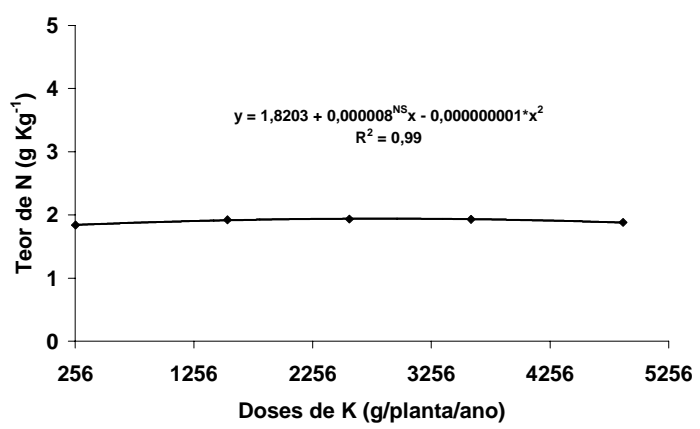

Figura 20 - Teor de nitrogênio em folhas de coqueiro no $7^{\circ}$ ano de produção para duas épocas de amostragem (junho e dezembro de 2003) em função das doses de potássio aplicadas via fertirrigação

A ausência de resposta às doses de $\mathrm{N}$ pode ter ocorrido em relação à competição dos ânions $\left(\mathrm{Cl}^{-} / \mathrm{NO}_{3}{ }^{-}\right)$pelos sítios de absorção e de transporte na planta. Segundo Pessarakcli e Tucker (1988), altas concentrações de cloreto em solução prejudicam a absorção de nutrientes, principalmente o $\mathrm{N}$, devido à inibição competitiva entre os ânions cloreto e nitrato. Sampaio (1996) observou diminuição no teor de nitrato em 
pecíolos de tomateiro com o aumento do cloreto de potássio no solo. Outra hipótese seria o mecanismo de retroalimentação negativa. Conforme Marschner (1986), o nitrato é acumulado nos vacúolos de células radiculares, ou transportado pelo caule até as folhas, até passar a atuar este mecanismo, que controla a taxa de absorção. Segundo este autor o controle pode ser feito pelo nitrogênio reduzido ou pela forma nítrica.

Houve uma tendência de aumento do fósforo nas folhas (Figura 21) com o aumento do $\mathrm{N}$ fornecido ao solo pela fertirrigação.

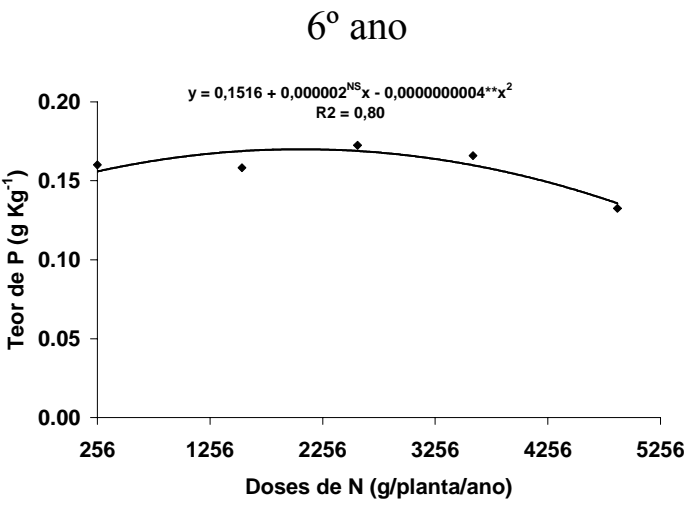

$7^{\circ}$ ano (junho de 2003)

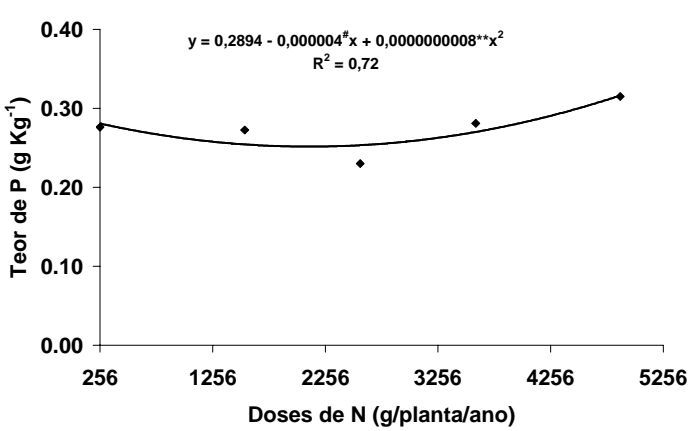

$7^{\circ}$ ano (dezembro de 2003)

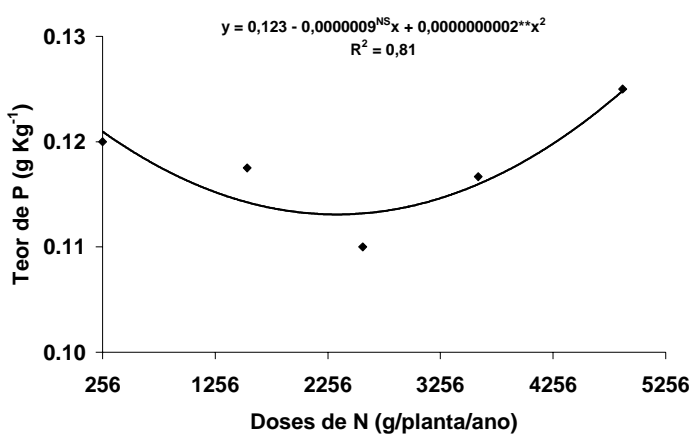

Figura 21 - Teor de fósforo em folhas de coqueiro no $6^{\circ}$ e $7^{\circ}$ ano de produção (junho e dezembro de 2003), em função das doses de potássio aplicadas via fertirrigação 
As condições ambientais, assim como para o $\mathrm{N}$, tiveram influência numa maior eficiência de absorção desse nutriente pela planta em junho de 2003. Percebe-se também, que as concentrações de fósforo, já nas menores doses de $\mathrm{N}$, são suficientes à nutrição do coqueiro para os dois anos de cultivo com base no nível crítico estabelecido em 0,12 \% (Kanapathy, 1971; citado por Camboim Neto, 2002). Esse favorecimento da absorção de $\mathrm{P}$ pelo $\mathrm{N}$ aplicado é bastante conhecido e é caracterizado como um sinergismo entre estes nutrientes.

Como se pode constatar, as exigências do coqueiro em fósforo são pequenas. No entanto Manciot et al. (1980) defende que o elemento é importante porquê entra na regeneração do ácido trifosfórico, geralmente abundante nos órgãos jovens, além de participar das reações ligadas ao transporte de energia.

Quanto ao potássio, as superfícies de respostas apresentadas na Figura 22, comprovam a grande exigência do coqueiro por esse nutriente. Os efeitos obtidos revelam que a nutrição potássica expressa comportamentos lineares à medida que aumenta as doses de potássio aplicadas e que o aumento das doses de $\mathrm{N}$ provoca uma depleção na concentração de K na folha do coqueiro. Lins (2000) atesta que a nutrição potássica reage positivamente à adubação e que as concentrações de $\mathrm{K}$ na folha quase duplicaram quando do uso de 1000 g planta $^{-1}$ ano $^{-1}$.

No $6^{\circ}$ ano de produção, referente ao primeiro ano de estudo, doses de $\mathrm{K}$ a partir de $1539 \mathrm{~g} \mathrm{planta}^{-1}$ ano $^{-1}$ estabeleceram níveis favoráveis à nutrição do coqueiro com base na faixa de nível crítico estabelecido (Kanapathy, 1971; citado por Camboim Neto, 2002). Esses níveis são praticamente duplicados em comparação com a aplicação da maior dose de $\mathrm{K}$ (4872 $\mathrm{g}_{\text {planta }}{ }^{-1}$ ano $^{-1}$ ) chegando acima de $15 \mathrm{~g} \mathrm{~kg}^{-1}$ sua concentração na matéria seca da folha.

$\mathrm{O}$ aporte de $\mathrm{K}$ no $7^{\circ}$ ano de produção, referente ao segundo ano de estudo, sofreu um aumento relevante, em relação ao $6^{\circ}$ ano, quando se considera a análise da concentração do K realizada em junho de 2003. Quando se compara as 2 análises realizadas no segundo ano, percebe-se uma considerável diferença nas consentrações de $\mathrm{K}$ na folha do coqueiro em relação às doses aplicadas de $\mathrm{N}$ e K. Condições climáticas mais favoráveis à cultura, como já defendido anteriormente, provavelmente tiveram 
influência numa maior eficiência de absorção desse nutriente pela planta em junho de 2003. Entretanto, em decorrência do menor desenvolvimento vegetativo da planta, em razão de maior incidência de doenças no período, já mencionadas anteriormente, o potássio pode ter se concentrado na folha superestimando os valores em condições ideais.

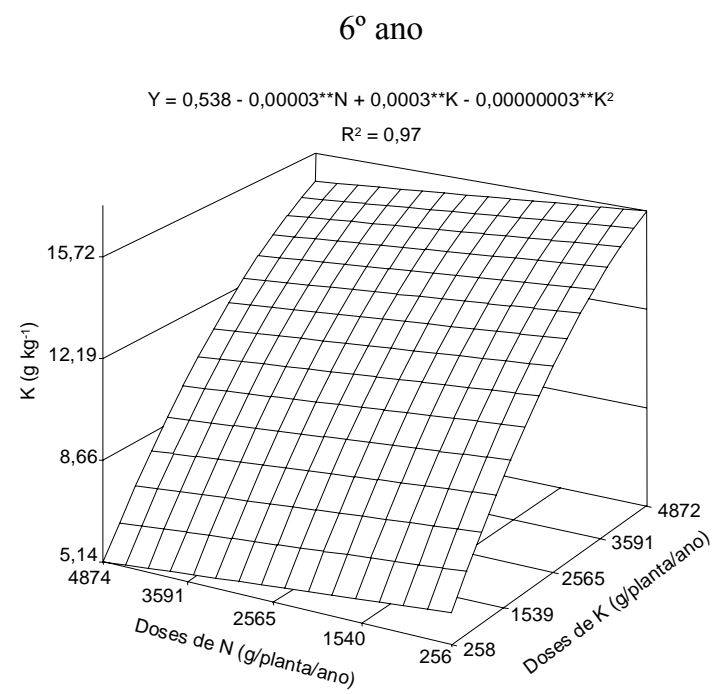

$7^{\mathrm{o}}$ ano (junho de 2003)

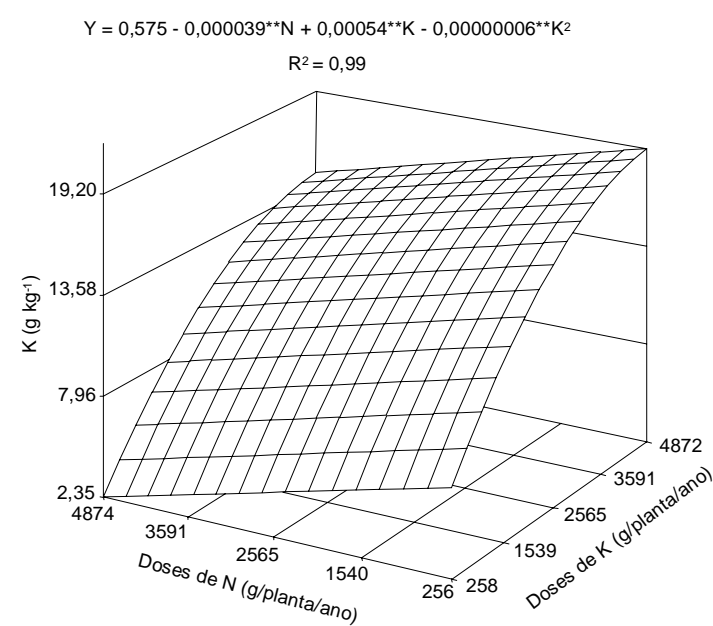

$7^{\circ}$ ano (dezembro de 2003)

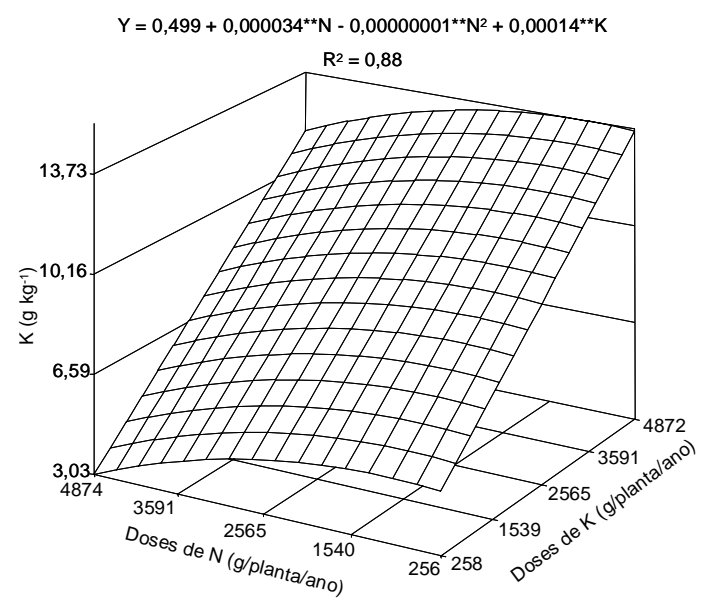

Figura 22 - Superfície de resposta do teor de potássio em folhas de coqueiro no $6^{\circ}$ e $7^{\circ}$ ano de produção (junho e dezembro de 2003), em função das doses de nitrogênio e potássio aplicadas via fertirrigação 
Há uma tendência de estabilização e diminuição da concentração de potássio pelo coqueiro híbrido ao longo do cultivo (Lins, 2000). Doses de K acima de $2565 \mathrm{~g} \mathrm{planta}^{-1}$ no $7^{\circ}$ ano de produção possibilitam, de forma confiável, uma concentração satisfatória (acima de 8,0 $\mathrm{g} \mathrm{kg}^{-1}$ ) deste nutriente na planta com base nos níveis críticos preestabelecidos (Kanapathy, 1971; citado por Camboim Neto, 2002). Os sintomas visuais de escassez de potássio manifestam-se com teores foliares abaixo de $5 \mathrm{~g} \mathrm{Kg}^{-1}$, quando as plantas já estão em processo severo de deficiência nutricional (Ollivier, 1993).

A correlação entre as concentrações de $\mathrm{K}$ na folha e a produção média de frutos (Figura 23), em relação às dosagens empregadas, teve bons níveis apenas para o $6^{\circ}$ ano de produção, mostrando que o crescimento no aporte de potássio nas folhas acompanha o aumento na produção de frutos. Já para o $7^{\circ}$ ano de produção esse comportamento não foi verificado. Observa-se neste ano que a concentração de K, apesar de ser crescente, não acompanhou a produção de frutos, não se obtendo ajuste aceitável aos modelos matemáticos usualmente empregados. Isto indica que a maioria do $\mathrm{K}$ assimilado era carreado para os frutos, já que a água de coco concentra boa parte do potássio exigido pela planta. Provavelmente devido a isto, as doses de $\mathrm{K}$ aumentaram o conteúdo deste na planta, já que a absorção do nutriente é regulada pela concentração interna na planta, dependendo do status nutricional.

$6^{\circ}$ ano de produção

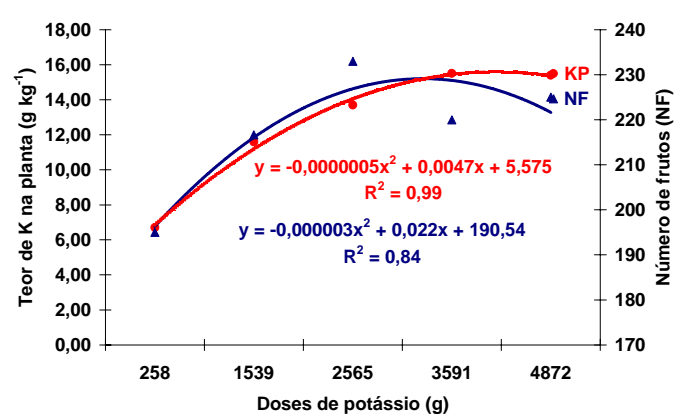

$7^{\circ}$ ano de produção

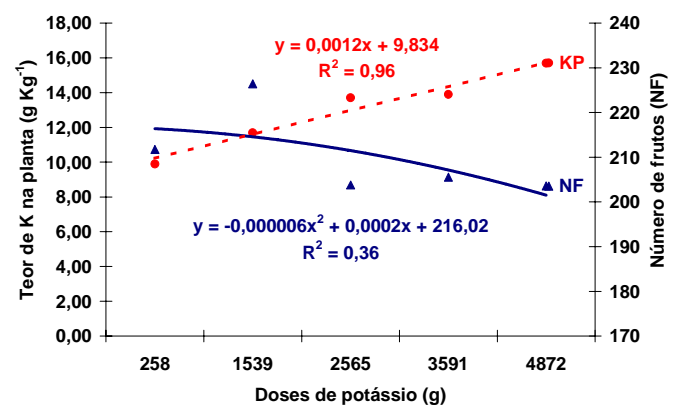

Figura 23 - Correlação entre a concentração de K na folha e produção média de frutos no $6^{\circ}$ e $7^{\circ}$ ano de produção, em função das doses de potássio aplicadas via fertirrigação 
No $6^{\circ}$ ano de cultivo a dose de $\mathrm{K}$ de maior rentabilidade correspondeu a $2786 \mathrm{~g}$ planta $^{-1}$ ano $^{-1}$ com produção estimada em 229 frutos planta $^{-1}$ ano $^{-1}$. Aos teores de K na folha no $6^{\circ}$ ano de cultivo, foi ajustado um modelo de regressão quadrática estimando-se um valor de $14,8 \mathrm{~g} \mathrm{~kg}^{-1}$ de potássio na matéria seca para a dose de $\mathrm{K}$ de maior rendimento por planta. No $7^{\circ}$ ano de cultivo para todas as doses de potássio, a produção de coco verde situou-se acima de 200 frutos planta $^{-1}$ ano $^{-1}$, não se obtendo ajuste aceitável aos modelos matemáticos usualmente empregados. Neste mesmo ano o teor de $\mathrm{K}$ na folha seguiu um modelo de regressão linear com valor médio de $12,75 \mathrm{~g} \mathrm{~kg}^{-1}$ de K na matéria seca.

Os teores de magnésio variaram em torno dos níveis críticos $\left(3,0 \mathrm{~g} \mathrm{~kg}^{-1}\right)$ descritos por Kanapathy (1971) citado por Camboim Neto (2002). O aumento na dose de N e de K no solo deprimiu o teor de magnésio nas folhas do coqueiro, no $6^{\circ}$ e $7^{\circ}$ ano de produção (Figura 24).

Outra hipótese seria a velocidade de absorção do $\mathrm{K}$ em relação ao $\mathrm{Mg}$, deprimindo a absorção deste último, assim como ocorre com o Ca (Marschner, 1995). O fato de ser monovalente e de menor grau de hidratação, confere ao $\mathrm{K}$ absorção preferencial em relação aos divalentes (Kabata Pendias \& Pendias, 1984).

Os teores de sódio (Figura 25) variaram em torno do nível crítico $\left(2,0 \mathrm{~g} \mathrm{Kg}^{-1}\right)$ descrito por Kanapathy (1971) citado por Camboim Neto (2002). Os terores satisfatórios de sódio na folha do coqueiro advêm de aplicações com cloreto de sódio em anos anteriores ao período de estudo. Observa-se na Figura 25, uma tendência de diminuição de seus teores na folha do coqueiro com o passar do tempo. As concentrações de sódio em função das doses de potássio tem comportamento descendente apresentando o efeito depressivo deste cátion sobre a concentração foliar do sódio. Pode-se assumir a explicação dada anteriormente em relação a interação competitiva entre o $\mathrm{K}$ e o $\mathrm{Mg}$. Sobre este aspecto, Marschner (1995) relata que o sódio estimula o crescimento de algumas espécies de plantas, devido à importância desse elemento nos processos de expanção celular e balanço hídrico, substituindo o potássio em alguns processos metabólicos, pelo acúmulo de íons de $\mathrm{Na}$ (soluto) nos vacúolos e ao mais rápido fechamento dos estômatos das plantas supridas de sódio e potássio em ralação às plantas 
supridas unicamente de potássio. Porém, Marinho (2002) indica haver um limite no acúmulo iônico nas folhas do coqueiro, já que o aumento nos teores de sódio na folha não foi proporcional às concentrações encontradas no solo quando as plantas foram tratadas com água salina.

\section{$6^{\circ}$ ano}

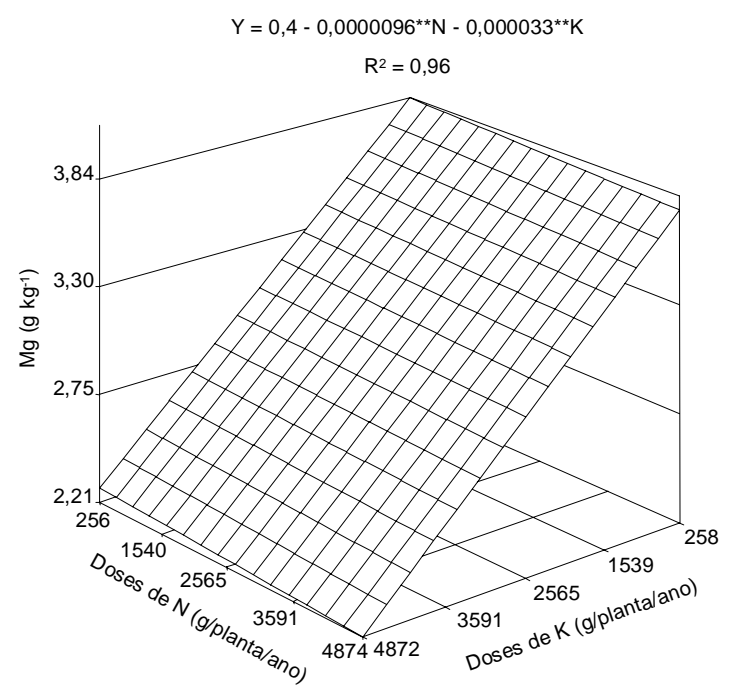

$7^{\circ}$ ano (junho de 2003)

$7^{\circ}$ ano (dezembro de 2003)
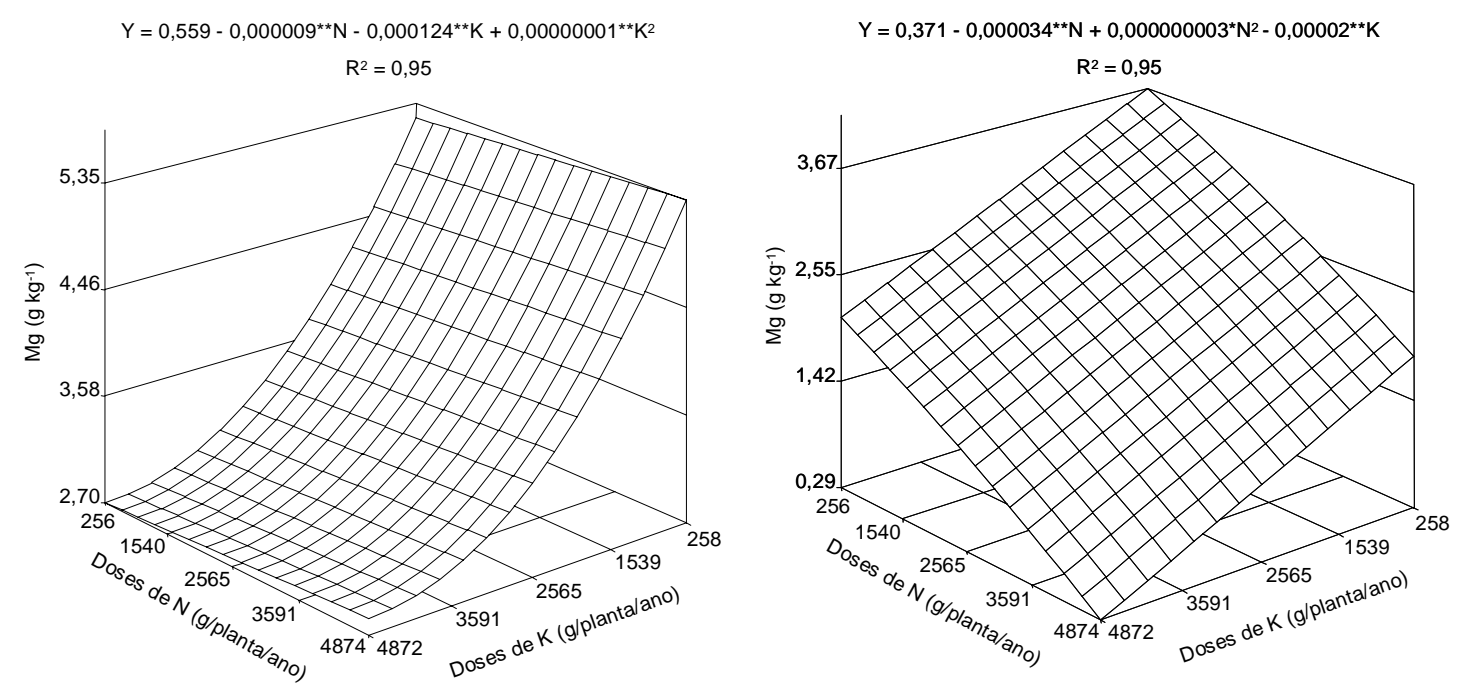

Figura 24 - Superfície de resposta do teor de magnésio em folhas de coqueiro no $6^{\circ}$ e $7^{\circ}$ ano de produção (junho e dezembro de 2003), em função das doses de nitrogênio e potássio aplicadas via fertirrigação 
Portanto, o sódio manteve-se em níveis ideais para a cultura do coqueiro, sem representar perigos quanto aos problemas causados por toxicidade e/ou antagonismo iônico.

$6^{\circ}$ ano

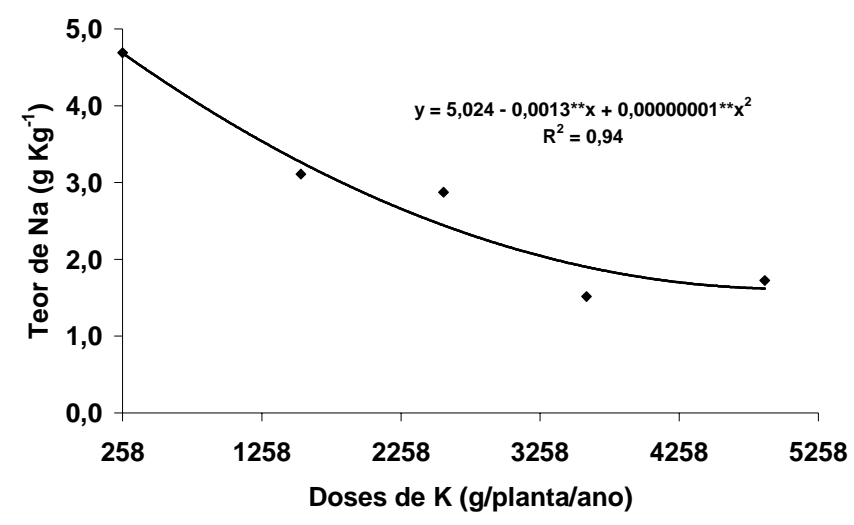

$7^{\circ}$ ano (dezembro de 2003)

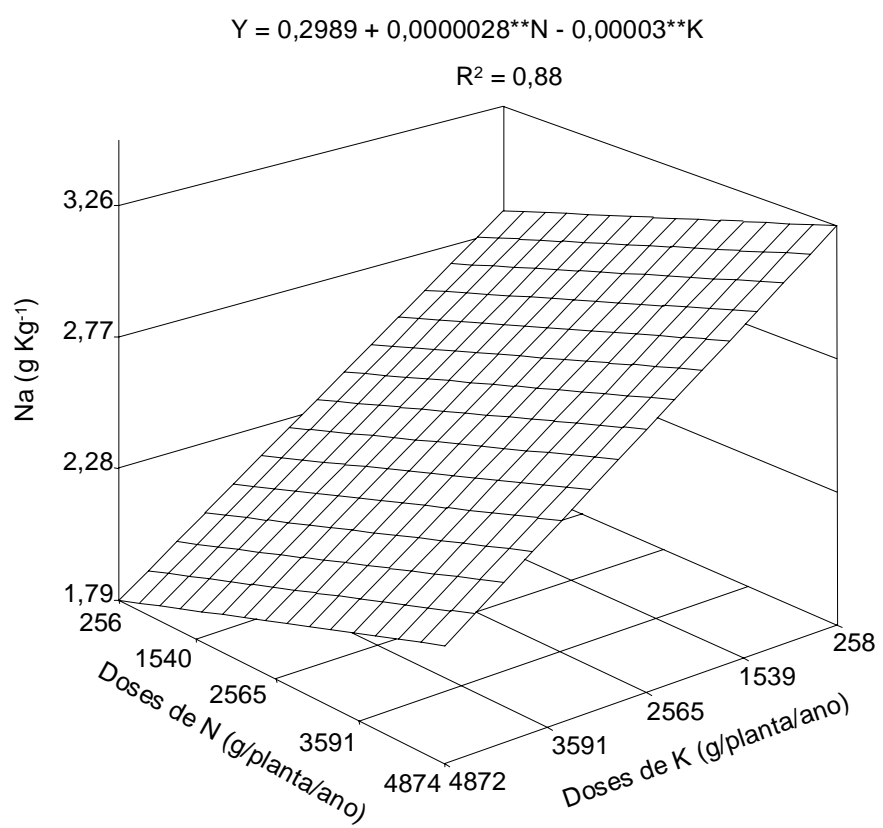

Figura 25 - Superfície de resposta do teor de sódio em folhas de coqueiro no $6^{\circ}$ e $7^{\circ}$ ano de produção, em função das doses de nitrogênio e potássio aplicadas via fertirrigação 
O cloreto é tratado em relação às concentrações presentes no coqueiro como um macronutriente. De acordo com Marschner (1995) esse nutriente tem função na fotossíntese e na regulação osmótica da planta, tendo ainda ação na resistência à seca e às doenças fúngicas (Ollagnier et al., 1983). O teor de cloro nas folhas para o $6^{\circ}$ ano de produção sofreu efeito positivo (Figura 26) em relação ao aumento das doses de K com um bom ajuste de correlação $\left(r^{2}=93 \%\right)$. Na análise realizada no $7^{\circ}$ ano a superfície de resposta não mostrou uma correlação aceitavel $\left(\mathrm{r}^{2}=36 \%\right)$. Neste ano o $\mathrm{Cl}$ teve uma tendência de diminuição a medida em que se incrementava as doses de $\mathrm{N}$, com uma redução máxima acima de 75\%. Essa tendência à redução se deu linearmente sem que o aumento nas doses de $\mathrm{K}$ (via $\mathrm{KCl}$ ) imprimissem uma retomada nos níveis de $\mathrm{Cl}$ nas folhas. Segundo Ollagnier et al. (1983), não pode haver dúvida ao interpretar as respostas para a aplicação com $\mathrm{KCl}$ sem referência à nutrição com cloro, que é de vital importância para o coqueiro.

Portanto, as concentrações de $\mathrm{Cl}$ encontradas nos dois anos de estudo foram satisfatórias quanto ao suprimento desse nutriente à planta, sendo alcançado mesmo nas menores doses de $\mathrm{K}$ (via $\mathrm{KCl}$ ) aplicadas na fertirrigação.

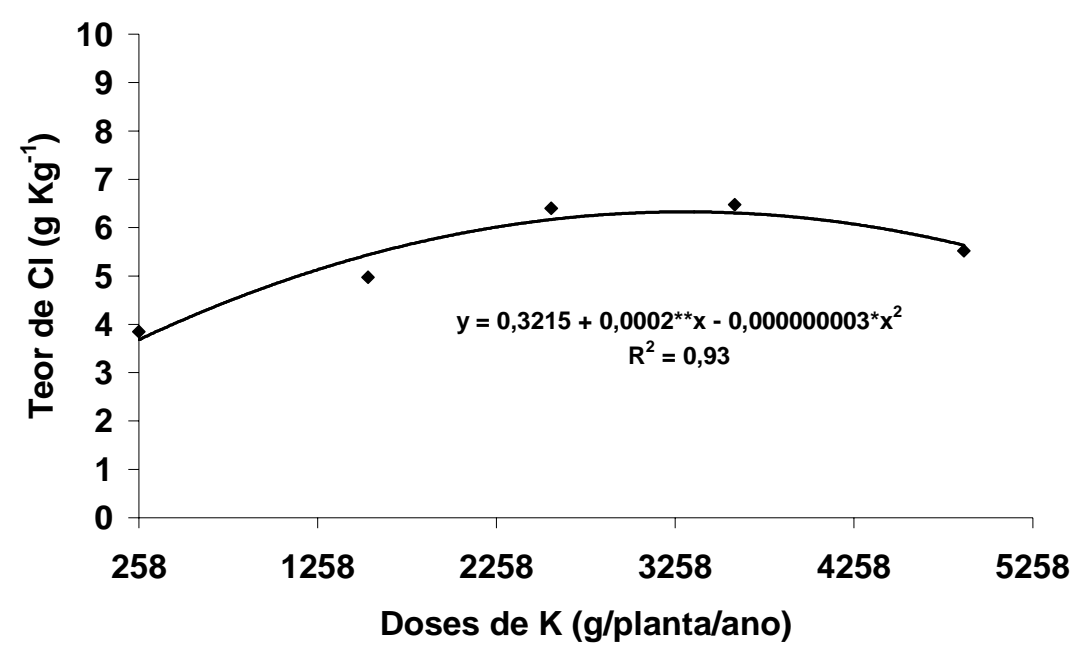

Figura 26 - Concentração de $\mathrm{Cl}$ na folha no $6^{\circ}$ ano de produção, em função das doses de potássio aplicadas via fertirrigação 
Tentou-se estabelecer tendências de variação dos teores de micronutrientes presentes na folha do coqueiro, observando-se a flutuação dos mesmos em função das diferentes doses de nitrogênio e potássio utilizadas na fertirrigação. Os modelos matemáticos não mostraram boas correlações para a maioria dos efeitos significativos encontrados nos teores de micronutrientes, embora tenha se observado uma tendência de melhores correlações ao longo das avaliações. Isso é comprovado pela diminuição da variação das amostragens.

Com relação ao $6^{\circ}$ ano de cultivo (Figura 27), as curvas mostram uma leve influência no declínio do teor de zinco (Figura 27,A) com o incremento das doses de nitrogênio e acréscimo do ferro (Figura 27,B) na folha do coqueiro à medida que aumentaram as doses de potássio.

Em coqueiro híbrido, Escoback \& Manciot (1981) observou que adubos à base de potássio e magnésio aumentaram significativamente os teores de zinco, enquanto que os adubos nitrogenados e fosfatados reduziram a absorção desse micronutriente. Para outras regiões e variedades as concentrações de 15 ppm de Zn são consideradas críticas para o coqueiro, porém não foram registrados sintomas de deficiência neste trabalho. Lins (1989) registrou níveis variando de 8,53 a 11,54 ppm de Zn, sem que houvesse sintomas de deficiência.

Os teores de ferro na folha do coqueiro, observados neste trabalho, ficaram bem acima dos valores considerados críticos para a cultura (40 ppm). Isso possivelmente trouxe melhorias na formação da clorofila e na participação dos processos fotossintéticos, de respiração e sobretudo na assimilação de nitrogênio e enxofre (Sobral, 1998). Segundo Wuidart (1994), é difícil diagnosticar a carência de ferro por intermédio através da diagnose foliar, uma vez que ainda não foi possível determinar com precisão o nível ótimo do elemento na folha, que segundo Escoback \& Manciot (1981), para coqueiros adultos, deverá estar acima de 40 ppm de Fe. Lins (1989) registrou níveis variando de 43 a 90 ppm de Fe. 
(A)

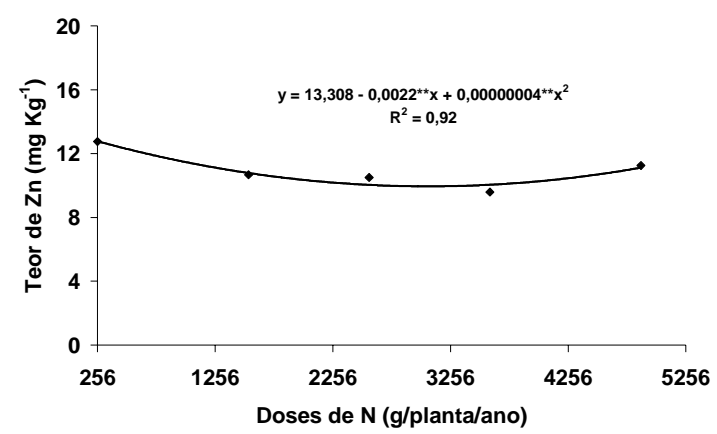

(B)

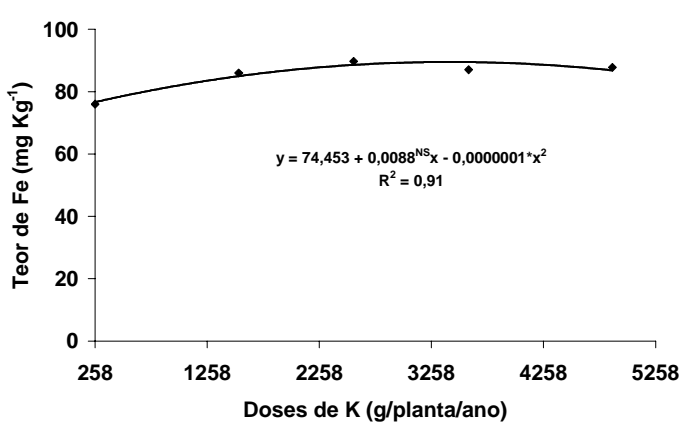

Figura 27 - Teor de zinco (A) e ferro (B) em folhas de coqueiro no $6^{\circ}$ ano de produção, em função das doses de nitrogênio e potássio aplicadas via fertirrigação

A concentração do manganês na folha como é mostrada na Figura 28 para o $6^{\circ} \mathrm{e}$ $7^{\circ}$ ano de cultivo, ficou acima de $20 \mathrm{mg} \mathrm{Kg}^{-1}$ e inferiores a $500 \mathrm{mg} \mathrm{Kg}^{-1}$, considerados baixos e tóxicos, respectivamente, em plantas da família palmae. Observa-se uma uniformidade na tendência de aumento linear do teor de Mn na folha do coqueiro com o incremento nas doses de nitrogênio no solo. Mills \& Jones (1996) defendem que isso ocorre quando o solo, pobre em microrganismos, diminui a oxidação deste elemento, aumentando a concentração no solo e conseqüentemente causando uma maior absorção pela planta. Segundo Malavolta (1980), o Mn é ativamente absorvido pela planta como $\mathrm{Mn}^{++}$e esta absorção é prejudicada por altas concentrações de outros cátions como o potássio. Entretanto, o que pode estar relacionado à não constatação deste efeito é o aumento na concentração de nitrato $\left(\mathrm{NO}_{3}{ }^{-}\right)$destinado ao sinergismo com o potássio.

De acordo com Malavolta \& Neptune (1983), a utilização de adubos fisiologicamente ácidos, a exemplo da uréia, reduz o pH e o teor de Ca trocável do solo, determinando, por outro lado, aumento no teor foliar de Mn que chega a atingir níveis tóxicos. Porém, para Casarini (2005), a diminuição no valor do pH do solo aumenta a diluição do Mn promovendo sua absorção pela planta. Silva (2001) verificou que a aplicação de doses crescentes de $\mathrm{N}$, utilizando uréia como fonte, reduziu o $\mathrm{pH}$ do solo e que isso favoreceu a elevação do teor de $\mathrm{Mn}$ nas folhas de bananeira. $\mathrm{O}$ autor diz ainda, 
que houve uma correlação negativa entre a produção da banana e o teor desse nutriente na folha, sendo comprovado mais tarde em outro trabalho (Silva et al., 2003).

$$
6^{\mathrm{o}} \text { ano }
$$

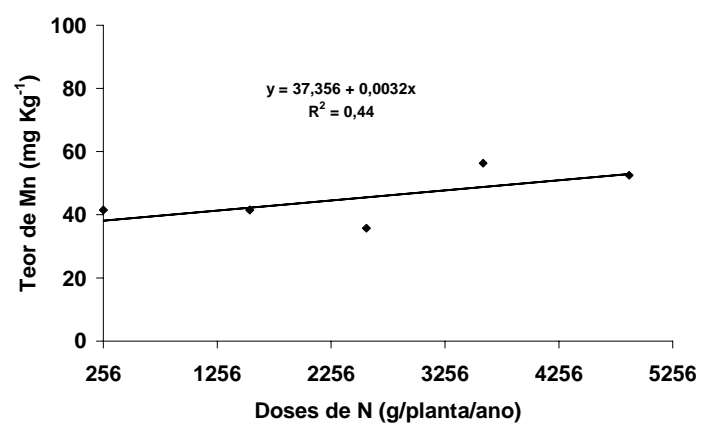

$7^{\circ}$ ano (junho de 2003)

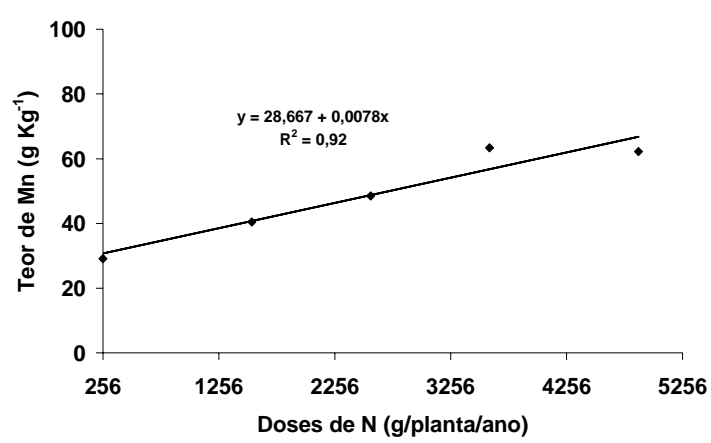

$7^{\circ}$ ano (dezembro de 2003$)$

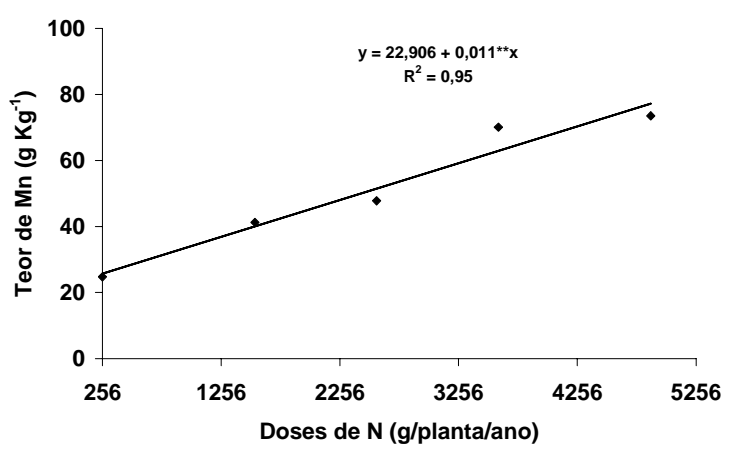

Figura 28 - Teor de manganês em folhas de coqueiro no $6^{\circ}$ e $7^{\circ}$ ano de produção, neste para duas épocas de amostragem (junho e dezembro de 2003), em função das doses de nitrogênio aplicadas via fertirrigação 


\section{CONCLUSÕES}

Com base nos resultados obtidos e nas condições de estudo, foram estabelecidas as seguintes conclusões:

- O comportamento vegetativo do coqueiro é influenciado pelas doses de $\mathrm{N}$ e $\mathrm{K}$ aplicadas via fertirrigação.

- As doses de $\mathrm{N}$ e K aplicadas na fertirrigação não exercem efeito no intervalo entre emissões de inflorescências do coqueiro anão verde.

- Doses de $2565 \mathrm{~g}_{\text {planta }}{ }^{-1}$ ano $^{-1}$ de K e $1540 \mathrm{~g} \mathrm{planta}^{-1}$ ano $^{-1}$ de N, proporcionam maiores médias na quantidade de flores femininas por planta.

- O aumento excessivo nas dosagens de $\mathrm{N}$ proporciona redução na média do número de flores femininas por inflorescência. O potássio é mais reivindicado pela planta no aumento do número de flores femininas do coqueiro.

- A dose de 2910 g planta $^{-1}$ ano $^{-1}$ de K e 2353 g planta $^{-1}$ ano $^{-1}$ de N, representam as maiores médias de produção de frutos por planta para o $6^{\circ}$ ano de cultivo.

- No $7^{\circ}$ ano de cultivo a dose de nitrogênio, com maior expressividade na produção média de frutos, foi de $2300 \mathrm{~g}_{\text {planta }}{ }^{-1} \mathrm{ano}^{-1}$.

-A dose econômica na fertirrigação para o $6^{\circ}$ ano de produção correspondeu a $2243 \mathrm{~g}$ de $\mathrm{N}$ planta $^{-1}$ ano $^{-1}$ e $2786 \mathrm{~g}_{\text {de }} \mathrm{K}_{2} \mathrm{O}$ planta $^{-1}$ ano $^{-1}$. 
- O peso dos frutos não sofre influência das doses de $\mathrm{N}$ e K. O aumento da adubação de $\mathrm{N}$ diminui o volume, o ${ }^{\circ}$ Brix da água de coco e por outro lado aumenta o $\mathrm{pH}$ da água de coco. $\mathrm{O}$ aumento de $\mathrm{K}$ reduz a CEac e favorece ao aumento do ${ }^{\circ}$ Brix da água de coco;

- Ocorre um gradiente de concentração dos índices de fertilidade à partir da superfície do solo. Os teores dos nutrientes na profundidade de $0-20 \mathrm{~cm}$ do solo são mais representativos, sendo encontrados em maiores quantidades no período chuvoso;

- No sexto ano de cultivo os teores dos nutrientes no solo apresentam grande variação tendendo a diminuir ao longo do período. Com o aumento das doses de $\mathrm{N}$ diminuem os teores de $\mathrm{Ca}, \mathrm{Mg}$ e aumenta a acidez, entretanto proporcionam aumento do $\mathrm{P}$ no solo e na folha do coqueiro.

- Os teores de $\mathrm{K}$ na folha são incrementados com seu aumento nas doses de fertirrigação mostrando grande correlação com a produção de frutos no $6^{\circ}$ ano de cultivo.

- A aplicação de $\mathrm{K}$ no solo eleva o teor de $\mathrm{Cl}$ e $\mathrm{Mg}$ nas folhas e diminui o teor de $\mathrm{Na}$.

- A aplicação de N no solo eleva o teor de Mn e diminui o teor de Zn nas folhas. 


\section{REFERÊNCIAS BIBLIOGRÁFICAS}

ALLEN, R.G.; PEREIRA, L.S.; RAES, D.; SMITH, M. Crop evapotranspiration: gigelines for computing crop water requirements. Roma: FAO, 1998. 300 p. (Paper $56)$.

ANUÁRIO ESTATÍSTICO DO BRASIL. Instituto Brasileiro de Geografia e Estatística. IBGE, v.64 Rio de Janeiro, 2004.sp.

ARAGAO, W. M. ; COSTA, A. S. ; SANTOS, H. C. Á. C. Florescimento de cultivares de coqueiro. In: XVI ENCONTRO DE GENÉTICA DO NORDESTE, 2002, São Luiz, p. 132-132. 2002.

ARAGÃO, W. M; CRUZ, E.M.O; HELVÉCIO, J.S., Caracterização morfológica do fruto e química da água de coco em cultivares de coqueiro anão (Cocos nucifera L. var. Nana). Revista Agrotrópica, v.13, n.1, p-56-70.2001.

AYERS, R. S.; WESTCOT, D. W. A qualidade da água na agricultura. Campina Grande: UFPB. Tradução de GHEYI, H. R.; MADEIROS, J. F.; DAMASCENO, F. A. 1991, 218p. (Estudos da FAO Irrigação e Drenagem, 29 revisado).

BEZERRA, J. W. T. Efeito da freqüência de irrigação no desenvolvimento radicular e produção do coqueiro anão. Fortaleza, 2002. 64 p. Dissertação (mestrado) Universidade Federal do Ceará. 
BLANCO, F.F. Tolerância do tomateiro à salinidade sob fertirrigação e calibração de medidores de íons específicos para determinação de nutrientes na solução do solo e na planta. Piracicaba, 2004. 115 p. Tese (Doutorado) - Escola Superior de Agricultura "Luiz de Queiroz”, Universidade de São Paulo.

BONDAR, G. O Coqueiro (Cocos nucifera, L.) no Brasil. Salvador: Naval, 1939. $100 \mathrm{p}$.

BURT, C.; O. CONNOR, K.; RUEHR, T. Fertigation. San Luis Obispo: California Polytenhnic State University, 1998. p. 15-42.

CADAHÍA, C. L. Cálculo e preparo de soluções fertilizantes. In: FOLEGATTI, M.V.; CASARINI, E.; BLANCO,F. F.;BRASIL, R. P. C. do.; Resende, R. S. (Coord.) Fertirrigação: Flores, Frutas e Hortaliças. Guaíba: Agropecuária, 2001. cap.4, p.145-162.

CAMBOIM NETO, L. de F. Coqueiro anão verde: influência de diferentes lâminas de irrigação e de porcentagens de área molhada no desenvolvimento, na produção e nos parâmetros físico-químicos do fruto. Viçosa, 2002. 121 p. Tese (Doutorado) Universidade Federal de Viçosa.

CASARINI, E. Doses de N e K aplicados via fertirrigação na cultura da roseira (rosa sp.) em ambiente protegido. Piracicaba, 2005. 101p. Tese (Doutorado) - Escola Superior de Agricultura “Luiz de Queiroz”, Universidade de São Paulo.

CASTRO, P. R. C.; KLUGE, R. A. Ecofisiologia de culturas extrativas: cana-deaçucar; coqueiro; dendezeiro e oliveira. Cosmópolis: Stoller do Brasil. 2001. 138p.

CHAILlARD, H.; DANIEL, C.; HOUETO, V.; OCHS, R. Oil palm and coconut irrigation on 900 ha "Experiment" in the Benin People's Republic. Oléagineux, v.38, n.10, p.529-533, oct. 1983 .

CHILD, R. Coconut. London: Longman, 1974. 335 p. 
CINTRA, F.L.D.; LEAL, M. L. S.; PASSOS, E.E.M. Distribuição do sistema radicular de coqueiros anões. Oléagineux, Paris, v.47, n.5, p. 225-234, 1992.

COELHO, A. M. Fertigação. In: COSTA, E. F. da; VIEIRA, R. F.; VIANA, P. A. (Eds.) Quimigação: aplicação de produtos químicos e biológicos via irrigação. Brasília: EMBRAPA-SPI, 1994. Cap. 8, p.201-227.

COOMANS, P. Influence de facteurs climatiques sur les fluctuations saisonnieres et annuelles de la production du cocotier. Oléagineux. v. 30, n.4, p.251-258, 1975.

COOMANS, P. Premiers résultats expérimentaux sur la fertilisation des cocotiers hybrides em Côte-d'Ivoire. Oléagineux. v. 32, n.4, p.155-166, 1977.

DOOREMBOS, J.; PRUITT, W. O. Necessidades hídricas das culturas. 1997. 204 p. (Estudos FAO - irrigação e drenagem n. 24).Traduzido por: Gheyi, H.R. et al. UFPB.

EMBRAPA. Centro de Pesquisa Agropecuária dos Tabuleiros Costeiros (Aracaju, SE). Coco produção aspectos técnicos. Aracaju, 2003. 106 p., il. (Frutas do Brasil; 27).

EMBRAPA. Centro de Pesquisa Agropecuária dos Tabuleiros Costeiros (Aracaju, SE). Recomendações técnicas para o cultivo do coqueiro. Aracaju, 1993. 49 p., il. (EMBRAPA-CPATC. Circular Técnica, 1).

EMBRAPA. Centro Nacional de Pesquisa de Solos. Manual de métodos de análise de solos. 2 ed. rev. e atual. Rio de Janeiro: EMBRAPA, 1997. 212p.

EMPARN. Caracterização física do fruto e composição química da água de coco de cultivares anão verde do jiqui, anão amarelo e híbrido PB 121 aos 5, 6, 78 e 9 meses de idade. In: SEMANA INTERNACIONAL DA FRUTICULTURA, FLORICULTURA E AGROINDÚSTRIA, 8., 2001, Fortaleza. O cultivo do coqueiro “Mini-curso”. Fortaleza: FRUTAL, 2001. 102 p.

ESCOBACH, J.M.; MANCIOT, R. Lês oligoelements dans la nutricion du cocotier. Oléagineux, v.36, n.6, p.291-304, 1981. 
FAO. Coconut tree of life. Rome: FAO. 1984. 446 p. (Plant Production and Protection Paper 57).

FAO. Disponível: http://apps.fao.org consultado no mês de janeiro de 2005.

FERREIRA NETO, M. Desenvolvimento e produção do coqueiro sob diferentes salinidades de água de irrigação. Campina Grande, 2001. 88p. Dissertação (Mestrado) - Centro de Ciências e Tecnologia, Universidade Federal da Paraíba.

FERREIRA NETO, M.; Gheyi, H.R.; Holanda, J.S. de; Medeiros, J.F. de.; Fernandes, P.D. Qualidade do fruto verde de coqueiro em função da irrigação com água salina. Revista Brasileira de Engenharia Agrícola e Ambiental, Campina Grande, v.6, n.1, p.69-75. 2002.

FERREIRA, J.M.S.; WARWICK, D.R.N.; SIQUEIRA, L.A. A Cultura do coqueiro no Brasil. Aracaju-SE: EMBRAPA-CPATC, 1997.

FERRI, M. G. Botânica: morfologia interna das plantas. Local: Melhoramentos, 1973. 113 p., il.

FRÉDMOND, Y.; ZILLER R.; NUCÉ de LAMOTHE, M. de El cocotero: técnicas agrícolas y producciones tropicales. Barcelona: Editorial Blume, 1966. 236p.

FREMOND. Y.; OUVRIER, M. Importance pour le cocotier d'une nutrition minérale convenble dès la plantation sur sable côtier. Oléagieux, v.26, n.10, p.609-616, 1971.

FREMOND. Y.; ZILLER, R.; LAMOTHE, M.N. El Cocotero. Barcelona: Blume, 1975. 236 p. (Coleccion Agricultura tropical).

FRIZONE, J. A.; ZANINI, J.R., PAES, L. A. D.; NASCIMENTO, V. M. Fertirrigação mineral. 1 ed. Ilha Solteira, SP : UNESP, 1985, v.1. p.31.

FRIZZONE, J. OLLITA, A. F. L; PEREIRA, G. T. Funções de resposta do feijoeiro (Phaseolus vulgaris, L.) ao uso de nitrogênio e lâmina de irrigação: I- região de produção nacional. Irrigação e Tecnologia Moderna. 1987. n.28. p 26-32.

GOMES, R.P. O coqueiro-da-baía. 6. ed. São Paulo: Nobel, 1992. 111 p. 
GRIMWOOD, E.B. Los Productos del cocotero: su elaboración en los países en desarrollo. Roma: FAO, 1977. 279 p. ( Boletin $\mathrm{N}^{\mathrm{o}} 7$ ).

IBGE - Sistema de recuperação automática SIDRA. PRODUÇÃO AGRÍCOLA MUNICIPAL IBGE- Rio de Janeiro: Disponível: http://www.ibge.gov.br Acesso em 12/out./2003.

IRHO. Coconut: water supply and drought tolerance. Oléagineux, v.47, n.6, p. 334-337, 1992.

IRHO. Rapport d'activité. Oléagineux, v. 44, n.4, p.1-22, 1989.

JAYAKUMAR, M.; SASEENDRAN, S.A.; HEMAPRABHA, M. Crop coefficient for coconut (Cocos nucifera L.): a lysimetric study. Agricultural and Forest Meteorology, v.43, p. 235-240, 1987.

JAYASEKARA, K. S.; JAYASEKARA, C. Eficiency of water use in coconut under different soil/plant management systems. In: NAIR, M. K.; KHAN, H. H.; GOPALASUNDARM, P.; BHASKAARARAO, E. V. V. ed. Advances in coconut research and development. New Delhi: ISOCRAD, 1993. 427p.

JOLY, A.B. Botânica: introdução à taxonomia vegetal. 11. ed. São Paulo: Nacional, 1993. p. 704-708, il.

JUCÁ, M. P.; GAÍVA, H. N.; PEREIRA, W. E.; MILESKI, A. Comportamento vegetativo de seis cultivares de coqueiro-anão (Cocos nucifera L.), em Santo Antônio de Leverger - MT. Revista Brasileira de Fruticultura, v.24, n.2, p.463467, 2002.

KABATA PENDIAS, A.; PENDIAS, H. Trace elements in soils and plants. Boca Raton: CRC Press, 315 p. 1984.

KIEHL, E.J. Fertilizantes organominerais. 3. ed. Piracicaba: 1999. 146 p., il.

KUMAR, B.J.; SHETTY, S.N.; GOWDA, D.K.V. Electrolyte content of coconut water as influenced by age of coconut. Indian Veterinary Journal,v.52, p.38-42, 1975. 
KUSHWAH, B. L.; NELliAT, E. V.; MORKAVE, V. T.; SUNNY, A. F. Rooting pattern of coconuts (Cocos nucifera L.). Indian Coconut of Agronomy, v.18. p.7174, 1973.

LEITE, I. R. do M.; ENCARNAÇÃO, C. R. F. da. Fenologia do coqueiro na zona costeira de Pernambuco. Pesquisa Agropecuária Brasileira, v.37, n.6, p.745-752, 2002.

LEITE, R. de A. Uso de matrizes experimentais e de modelos estatísticos no estudo do equilíbrio fósforo-enxofre na cultura da soja em amostras de dois latossolos de Minas Gerais. Viçosa, UFV. 1984. 87 p. (Dissertação de Mestrado). Universidade Feral de Viçosa.

LINS, P. M. P. Atividades desenvolvidas pela pesquisa e situação fitossanitária do projeto SOCÔCO no ano de 1998: Relatório de consultoria. Moju, 40 p. 1998.

LINS, P. M. P. Resposta do coqueiro (Cocos nucifera L.) à aplicação de $\mathrm{N}, \mathrm{P}, \mathrm{K}$ e Mg nas condições edafoclimáticas de Moju-PA. Belém, 2000. 81 p. Dissertação (Mestrado) - Faculdade de Ciências Agrárias do Pará.

MAERTENS, C.; BLANCHER, R.; PIECH, J. Influence de différent régimes hidriques sue l'absortion l'eau et des éléments minéraux por les cultures. Annales of Agronomy, v.25, n.4, p.575-586, 1974.

MAHESHA, A. ABDUlKHADER, K.B.; RANGANNA, G. Consumptive use and irrigation requeriment of coconuts (Cocos nucifera) in coastal sandy soils. Indian Journal of Agricultural Sciences,v.13,n.5, p.13-15, Jan. 1992.

MALAVOLTA, E. Elementos de nutrição mineral de plantas. São Paulo: Ceres, 1980. $251 \mathrm{p}$.

MALAVOLTA, E. Manual de química agrícola. São Paulo: Agronômica Ceres, 528p. 1976. 
MALAVOLTA, E.; HAAG, H.P.; MELLO, F.A.F.; BRASIL SOBRINHO, M. O.C. Nutrição mineral e adubação de plantas cultivadas. São Paulo: Pioneira, 1974. p. 668-685, il.

MALAVOLTA, E.; NEPTUNE, A. M. L. Características e eficiência dos adubos nitrogenados. São Paulo: SN Centro de Pesquisa e Promoção de Sulfato de Amônio, 1983. 45p. (SN Boletim técnico, 2).

MALAVOLTA, E.; VITTI, G. C.; OLIVEIRA, S. A. Avaliação do estado nutricional das plantas: princípios e aplicações. 2. ed. Piracicaba: POTAFOS, 1997. 319 p.

MANCIOT, R. Instalação de uma plantação de coqueiros híbridos no Brasil. Relatório apresentado à SOCOCO, Moju-Pará, 98p., 1979.

MANCIOT, R.; OLLAGNIER, M.; OCHS, R. Nutricion mineral y fertilizacion del cocotero em la mundo. Oléagineux, v.35, n.1, p.13-27, 1980.

MARINHO, F. J. L. Germinação, crescimento e desenvolvimento do coqueiro anão verde sob estresse salino. Campina Grande, 2002. 196p. Tese (Doutorado) - Centro de Ciências e Tecnologia, Universidade Federal de Campina Grande.

MARSCHENER, H. Mineral nutricion of higher plants. London: Academic, $674 \mathrm{p}$. 1986.

MARSCHENER, H. Mineral nutricion of higher plants. 2. Ed. London: Academic Press, 888p. 1995.

MATHEW, C. Summer irrigation to coconut palm. Coconut Bulletin, v.3,n.1, p.2-3, 1972.

MEDINA, J.C.; GARCIA, J.L.M.;MARTIN, Z.J.; KATO, K.; TERUA, P.; TURATTI, J.M.; SANTOS L.C.; SILVA, M.T.C.; CANTO, W.L.; BICUDO NETO, L.C.; MORETTI, V.A. Coco: da cultura ao processamento e comercialização. In: Séries frutas tropicais 5. Campinas: editora, 1980. 285 p. 
MENON, R.P.V.; PANDALAI, R.M. The coconut palm: Monograph. Ernakulam: Indian Central Coconut Committee, 1958. 384 p.

MILLS, H. A.; BENTON JONES Jr. Plants analysis handbook. II: a practical sanpling, preparation, analysis and interpretation guide. Athens: MicroMacro, 1996. 422p.

MIRANDA JÚNIOR, J. P. Coqueiro anão. Rio de Janeiro: Ministério da Agricultura, 1948. $57 \mathrm{p}$.

MIRANDA, F.R.; OLIVEIRA, V.H.;SANTOS, F.J.S. Desenvolvimento de plantas jovens de coqueiro anão (Cocos nucifera $L$.) submetidas a diferentes regimes de irrigação. Fortaleza: EMBRAPA-CNPAT, 1998. 4 p.

MULIYAN, M. K.; NELLIAT E. V. Response of coconut palms to N, P and K fertilizer application on the west cost of India. Oléagineux, v.26, n.11, p.687-691, 1971.

NANNETTI, D. C. Nitrogênio e potássio aplicados via fertirrigação na produção, nutrição e pós-colheita do pimentão. Lavras, 2001. 184p. Tese (Doutorado) Universidade Federal de Lavras.

NOGUEIRA, L. C.; NOGUEIRA, L. R. Q.; MIRANDA, F. R. Irrigação do coqueiro. In: FERREIRA, J. M. S., WARWICK, D. R. N. E SIQUEIRA, L. A. A cultura do coqueiro no Brasil. 2 ed. Brasília, Embrapa-SPI; Aracaju, Embrapa-CPATC, 1997. p. $159-187$.

OCHS, R. Les contraintes écologiques du dévelopment des oléagineus pérennes (palmier et cocotier) em Afrique Occidentale et Centrale. Oléagineux, v. 32, n. 11, p. 461-477, 1977.

OHLER, J. G. Coconut, tree of life. Rome: FAO, 1984. 446p. (FAO. Plant Production and Protection Paper, 57).

OLLAGNIER, M.; OCHS, R. Interaction entre lazote et lê potassium dans la nutricion dês oléagineux tropicaux. Oléagineux, v.28, n.11, p.493-507, 1973. 
OLLAGNIER, M.; OCHS, R.; POMIER, M.; TAFFIN, G. de. Acción del cloro sobre el cocotero híbrido PB-121 em Costa do Marfim y Indonesia. Desarrollo, tolerancia a la sequia. Oléagineux, v.38, n.5, p.3093-321, 1983.

OLLAGNIER, M.; WAHYUNI, M. Mineral nutricion and fertilization of the Malayan Dwarf x west African Tall (PB-121-MAWA) hibryd coconut. Oléagineux, v.39, n.89, 1984.

OLLIVIER, J. Les synptômes de carence em potassium du cocotier. Oléagineux, v.48, n.11, p.483-489, 1993.

OUVRIER, M. Exportation par la récolte du cocotier PB-121 em function de la fumure potassique et magnésienne. Oléagineux, v.39, n.5, p.263-271, 1984.

OUVRIER, M.; TAFFIN, G. de. Evolucion de la matiére minerále des bourres de cocotier laissées au champ. Oléagineux, v.40, n.8-9, p.431-434, 1985.

PAPADOPOULOS, I. Fertirrigação: Processo de transição da fertirrigação convencional para a fertirrigação. In: FOLEGATTI, M.V.; CASARINI, E.; BLANCO,F. F.;BRASIL, R. P. C. do.; Resende, R. S. (Coord.) Fertirrigação: Flores, Frutas e Hortaliças. Guaíba: Agropecuária, 2001. cap.1, p.9-70.

PAR/CSIC Plan de modernización de los regadíos tradicionales de mula. 1999. Disponível em: < http://par.cebas.csic.es/par.htm>. Acesso em: 10 dez. 2000.

PARTHASARATHY, M. Drip irrigating coconuts. Indian Coconut Journal, v.15, n.7, p. 8-11. 1984.

PASSOS E. E. M. Exigências climáticas. In: FONTES, H. R.; RIBEIRO, F. E.; FERNANDES, M. F.; Coco Produção: aspectos técnicos. Brasília; Embrapa - SPI; Aracaju: Embrapa - CPATC, 2003. Cap 4, p. 18 - 20.

PASSOS, E.E.; SILVA, J.A. da. Fonctionnement des stomates de cocotier (Cocos nucifera) au chanp. Canadian Journal of Botany,v.68, p. 458-460, 1990. 
PASSOS, E.E.M. Ecofisiologia do coqueiro. In: FERREIRA, J.M.S.; WARWICK, D.R.N.; SIQUEIRA, L.A. (Ed.) A Cultura do coqueiro no Brasil. Aracaju: EMBRAPA-SPI, 1997. p. 65-72.

PEREIRA, A R; ANGELOCCI, L.R.; SENTELHAS, P.C. Agrometeorologia: Fundamentos e Aplicações Práticas. Ed. Agropecuária Ltda. 2002. 478p.

PEREIRA, J.B.A. Recomendações para a cultura do coqueiro. EMATER-RIO, 1998. 55 p., il.

PESSARAKLI, M.; TUCKER, T.C. Dry matter yield and nitrogen-15 uptake by tomatoes under sodium chloride stress. Soil Science Society of America Journal, v.52, n.3, p.698-700, 1988.

PINTO, J.M.; SOARES, J.M.; NASCIMENTO, T. Análise de coeficientes de uniformidade de distribuição de água em sistema de irrigação localizada. Petrolina: EMBRAPA-CPATSA, 1991. 24p. (EMBRAPA-CPATSA. Boletim de Pesquisa, 41).

PURSEGLOVE, J.W. Tropical crops monocotiledons. London: Longman, 1972. 607 p.

RAIJ. B. V. Fertilidade do solo e adubação. Piracicaba: CERES/POTAFOS, 1991. $343 p$.

RAMOS, V. H. V.; PINTO, A. C. de Q.; ARAGÃO, W. M.; GOMES, A. C.; JUNQUEIRA, N. T. V.; LOBATO, E.; OLIVEIRA, M. A. S. Comportamento de cultivares de coqueiro anão e híbridos no Distrito Federal. Revista Brasileira de Fruticultura, Jaboticabal, v. 26, n. 2, p. 363-365, 2004.

REYNOLDS, S. G. Grazing trials under coconuts in western Samoa. Tropical Grasslands, v.15, n.1, p.3-10, 1981.

RHOADES, J. D.; KANDIAH, A.; MASHALI, A. M. Uso de águas salinas para produção agrícola. Campina Grande: UFPB. Tradução de GHEYI, H. R.; SOUZA, J. R. de; QUEIROZ, J. E. 2000, 117p. (Estudos da FAO Irrigação e Drenagem, 48). 
RICE, R. C., BOWNAM, R. S., JAYNES, D. B. Percolation of waster below on irrigarion field. Soil Science Society. American Journal, v.50, p.855-859, 1986.

RODRIGUES, M. do R. L. Resposta do dendezeiro às aplicações de N, P, K e Mg nas condições edafoclimáticas de Manaus. Piracicaba, 1998. 156p. Tese (Doutorado) Escola Superior de Agricultura “Luiz de Queiroz”, Universidade de São Paulo.

ROSA JÚNIOR, C.D.R.M.; VIEIRA, V.J.S.; M. MELO, J.J.S.; SILVA FILHO, A. V. Coqueiro (Cocos nucifera L.): cultivo sob condição irrigada. 2. ed. Recife: SEBRAE/PE, 2000. 50 p. (Agricultura, 3).

ROSA, M de F.; ABREU, F.A.P. de. Água-de-coco: métodos de conservação. Fortaleza: EMBRAPA-CNPAT/SEBRAE/CE, 2000. 40 p. (EMBRAPACNPAT/SEBRAE/CE. Documento 37).

SAKURAI, N.; NEVINS, D. Changes in physical properties and cell wall polysaccharides of tomato (Lycopersicon esculentum) pericarp tissues. Physiologia Plantarum, v.89, n.4, p.681-686, 1993.

SAMPAIO, R.A. Produção, qualidade dos frutos e teores de nutrientes no solo e no pecíolo do tomateiro, em função da fertirrigação potássica e da cobertura plástica do solo. Viçosa, 1996. 117p. Tese (Doutorado) - Universidade Federal de Viçosa.

SÃO JOSÉ, A.R.; SOUZA, I.V.B.;MOURA, J. I. L.; REBOUÇAS, T. N. H. Coco: produção e mercado. Vitória da Conquista: UESB, 1999. 238 p.

SCHLINDWEIN, J. A.; ANGHINOMI, I. Variabilidade vertical de fósforo e potássio disponíveis e profundidades de amostragem do solo no sistema plantio direto. Ciência Rural, v. 30, n. 4, p. 611-617, 2000.

SHANMUGAM, K.S. Moisture management for coconut. Coconut Bulletin, v.4, n.7, p.2-10. 1973.

SILVA, J. T. A. da.; BORGES, A. L.; CARVAlHO, J. G.; DAMASCENO, J. E. A. Adubação com potássio e nitrogênio em três ciclos de produção da bananeira cv. 
prata-anã. Revista Brasileira de Fruticultura, Jaboticabal, v. 25, n. 1, p. 152-155, abr. 2003.

SILVA, J. T. A. Efeitodo nitrogênio sobre o $\mathrm{pH}$ do solo, absorção de $\mathrm{Mn}$ e produtividade de bananeira cv. Prata-Anã. In: CONGRESSO BRASILEIRO DE CIÊNCIA DO SOLO, 28, 2001, Londrina. Anais...Londrina: SBCS, 2001. (CD ROM).

SIQUEIRA, E.R.; RIBEIRO, F.L.; ARAGÃO, W.M. Melhoramento genético do coqueiro. In: FERREIRA, J.M.S.; WARWICK, D.R.N.; SIQUEIRA, L.A. (Ed.) A Cultura do coqueiro no Brasil. Aracaju: EMBRAPA-SPI, p. 73-98. 1997.

SOBRAL, L.F. Nutrição e adubação do coqueiro. In: FERREIRA, J.M.S.; WARWICK, D.R.N.; SIQUEIRA, L.A.; (eds) A Cultura do coqueiro no Brasil. 2 Ed. ver. AmplBrasília: Embrapa-SPI; Aracaju: Embrapa-CPATC, 1997. p.129-154.

SOBRAL, L.F.; SANTOS, Z.G. dos; LEAL, M. de L. da S.; Épocas de aplicação de fertilizantes e substituição parcial e total do $\mathrm{N}$ mineral por orgânico em coqueiro. In: REUNIÃO BRASILEIRA DE FERTILIDADE DO SOLO E NUTRIÇÃO DE PLANTAS, 23, 1998.

SOBRAL, L.F.; SANTOS, Z.G. Sistema de recomendação de fertilizantes para o coqueiro (Cocos nucifera L.) com base na análise foliar. Brasília: EMBRAPADDT, 1987. 23 p. (EMBRAPA-CNPCo. Documento, 7).

SOUSA, V. F. de; ANDRADE, C. L. T.; SOUSA, A. P. Redistribuição de água em água solo de textura arenosa sob irrigação por gotejamento. In: CONGRESSO BRASILEIRO DE ENGENHARIA AGRÍCOLA, 21, Santa Maria, 1992. Anais...Santa Maria: Sociedade Brasileira de Engenharia Agrícola, 1992, p.963-973.

SOUSA, V. F. de; SOUSA, A. P. Efeito da freqüência de aplicação de N e K por potejamento no estado nutricional e qualidade dos frutos do meloeiro (Cucumis melo L.). Engenharia Agrícola, v.17, n.3, p.36-45, 1998. 
SOUZA, F. E. de. Aspectos da cultura do coqueiro no nordeste. Recife: SUDENE, 1968. 123 p., $31 \mathrm{~cm}$. (Brasil. SUDENE. Agricultura, 14).

STEEL, R.G.D.; TORRIE, J.H. Principles and procedures of statistics: a biometrical approach. 2.ed. New York: McGraw-Hill, 1980. 633p.

TAMMES, P.M.L.;WHITEHEAD, R.A. Coconut (Cocos nucifera L.). In: Outlines of perennial cropbreedind in the tropics. 1969. p. 175-188.

TAVARES, M. Estudo da composição química da água de coco anão verde em diferentes estágios de maturação. In: CONGRESSO BRASILEIRO DE CIÊNCIA E TECNOLOGIA DE AlimENTOS, 16. 1998 Rio de Janeiro. Anais... Rio de Janeiro: SBCTA, 1998. v. 2, p.1262-1265.

THYE, K. K.; SOON, C. P.; CHEW, E. Effect of nitrogen application on coconut palms grown on coastal alluvial clay soils in Peninsular Malaysia. Proceeding of the East Malaysia Planter's Association, Cocoa Coconut Seminar, Tawau, Sabah, Malaisie, 18 p. 1971.

TISDALE, S.L.; NELSON, W.L.; BEATON, J.D.; HAVLIN, J.L. Soil fertility and fertilizers. 5.ed. New York: Macmillan Publishing, 1993. 634p.

TURRENT, F. A. La matriz experimental Plan Puebla, para ensayos sobre practicas de producción de cultivos. Agrociencia. V.19,p.1-27. 1980.

VITTI, G. C.; SUGIMOTO, S. S.; VITTI, D. C. C. Nutrição e adubação do coqueiro. Piracicaba: ESALQ-USP/GAPE/EMATER, 2001. 33 p.

VIVANCOS, A. D. Fertirrigation. Madrid: Mundi-Prensa. 1993. 217p.

WOLKWEISS, S. J. Química da acidez do solo. In: SEMINÁRIO SOBRE CORRETIVOS DA ACIDEZ DO SOLO, 2, Santa Maria, 1989. Anais... Santa Maria: Universidade Federal de Santa Maria, 1989. p.7-38.

WUIDART, W. Symptômes de carance em fer du cocotier sur sol corallien. Oléagineux, v. 49, n. 1. p. 31-34, 1994. 